\title{
488-D ASH BASIN VEGETATIVE COVER TREATABILITY STUDY
}

\section{FINAL REPORT FY02}

Christopher Barton, USDA Forest Service, Southern Research Station Don Marx, PHC Reclamation, Inc.

John Blake, USDA Forest Service, Savannah River Domy Adriano, UGA, Savannah River Ecology Lab Bon-Jun Koo, UGA, Savannah River Ecology Lab Stephen Czapka, USDA Forest Service, Southern Research Station 


\section{TABLE OF CONTENTS}

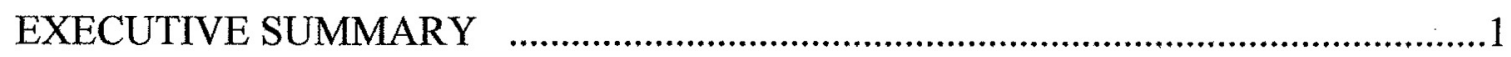

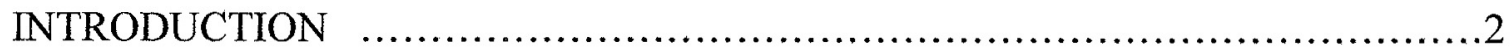

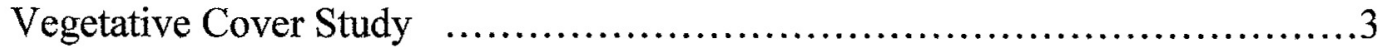

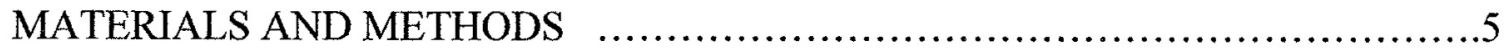

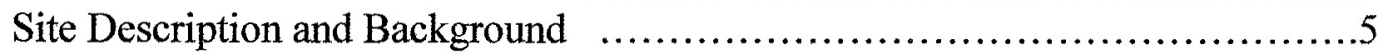

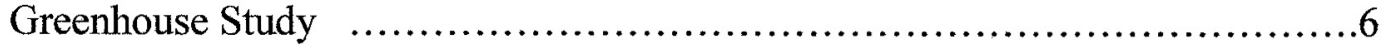

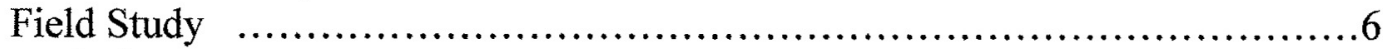

Hydrology and Soil Moisture Monitoring ....................................11

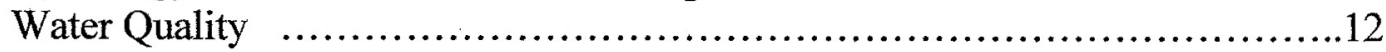

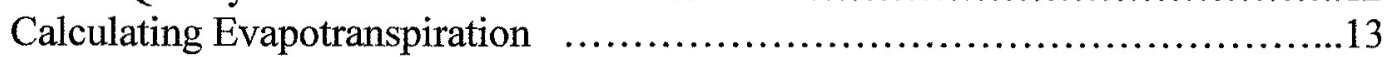

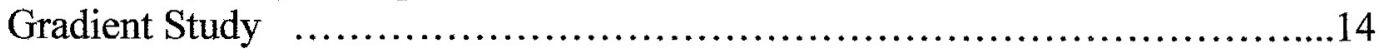

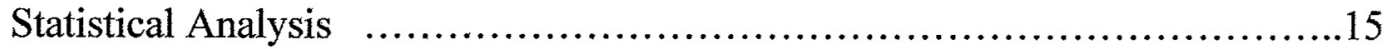

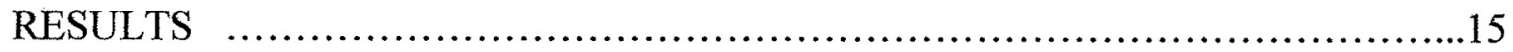

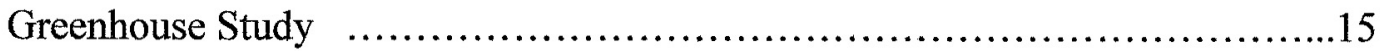

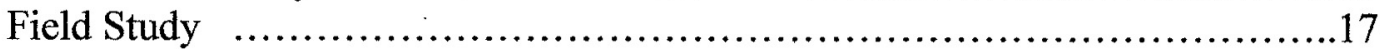

Soils and Sediment Characterization $\quad$.................................17

Vegetation Characterization ............................................21

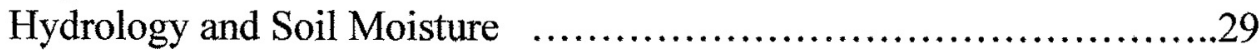

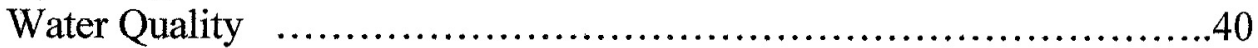

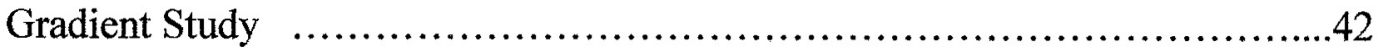

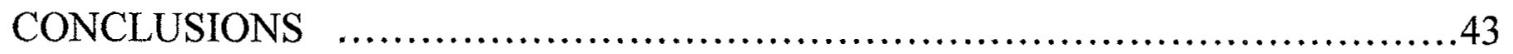

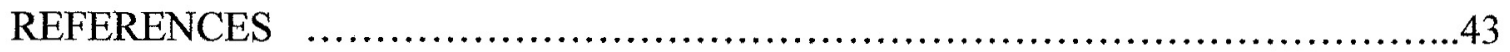

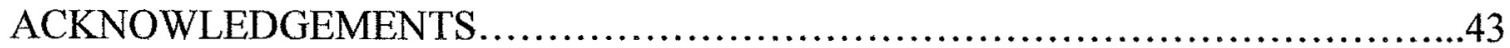

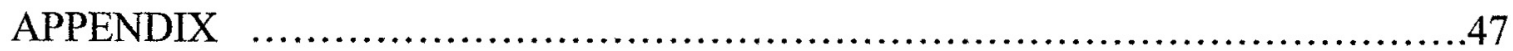




\section{LIST OF TABLES}

Table 1. Mean ectomycorrhizal index for 488-D containerized seedlings..........9

Table 2. Eluent chemistry from microencapsulation study.......................16

Table 3. Chemical characteristics of substrate materials prior to application......17

Table 4. Average $\mathrm{pH}(1: 1)$ of 488-D sediments at $0-10$ and $40-50 \mathrm{~cm}$ depths

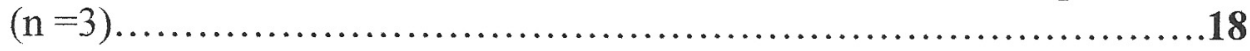

Table 5. Average EC (1:3) of 488-D sediments at $0-10$ and 40-50 cm depths $(\mathrm{n}=3)$

Table 6. Average total elemental composition of 488-D sediments at 0-10 and 40$50 \mathrm{~cm}$ depths $(\mathrm{n}=3)$.

Table 7. Carbon and nitrogen content of 488-D sediments at 0-10 and 40-50 cm depths $(n=3)$.

Table 8. Penetrometer resistance (psi) at the 488-D basin.

Table 9. Mean growth characteristics from seedlings harvested after one year $(n=4)$.

Table 10. Plant tissue nutrient composition after two growing seasons $(n=2) \ldots \ldots .27$

Table 11. Average total elemental composition $\left(\mathrm{mg} \mathrm{kg}^{-1}\right)$ of loblolly pine seedlings after one year growth $(\mathrm{n}=2)$.

Table 12. Biomass and species richness of naturally seeded grasses and weeds on the 488-D basin.

Table 13. Monthly rainfall at the 488-DAB during study period. 30

\section{LIST OF FIGURES}

Figure 1. Conceptual cross-section of the 488-D basin prior to vegetative cover establishment....................................................

Figure 2. Conceptual cross-section of the 488-D basin two years after vegetative cover establishment. 
Figure 3. Conceptual cross-section of the 488-D basin 7 years after vegetative cover establishment..................................................

Figure 4. Plot layout on the 488-D basin......................................

Figure 5. Surface $\mathrm{pH}(1: 1)$ prior to (April) and after (September) tillage.............8

Figure 6. Herbaceous plot layout.........................................10

Figure 7. Schematic of well and piezometer cluster............................11

Figure 8. Biomass of bahiagrass per container from greenhouse study

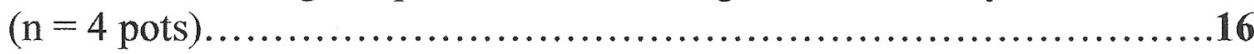

Figure 9. Soil temperature at 10-cm below surface on plots at the 488-D basin.....21

Figure 10. Vegetation survival by block on the 488-D basin....................22

Figure 11. Loblolly seedling growth by block for two growing seasons on the 488-D basin. Native soil was located on an uncontaminated plantation (SRWC) site at the Savannah River Site. Seedlings planted at the Native site were obtained from the same planting source as those on the basin............24

Figure 12. Vegetation survival by surface treatment and block on the 488-D basin..25

Figure 13. Pictures of seedlings in Block A - Apatite and Block B - Control treatments during second growing season...........................25

Figure14. Effect of surface treatment on survival of differing species on the 488-D basin.

Figure 15. Average survival of planted grass sprigs and associated sediment $\mathrm{pH}$ on the 488-D Ash Basin per surface treatment (2001 growing season)......28

Figure 16. Deviation of monthly rainfall from January 2001 through September 2002 as compared to the 50 year average ...................................30

Figure 17. SRS monthly rainfall versus evapotranspiration fromFebruary 2001 through September 2002 ..............................................

Figure 18. A graphical comparison of projected evapotranspiration rates on the 488D ash basin for the period January - September, 2002 ..................32

Figure 19. Soil moisture content from the TRIME sensor at various soil depths in a non-contaminated reference soil in 2001 
Figure 20. Soil moisture content at $25,50,100$, and $200 \mathrm{~cm}$ depths as detected by the TRIME TDR sensors in the Ash, Topsoil and Control plots on the 488-D basin.

Figure 21. Soil moisture distribution at various depths in the Block A-Topsoil and Control treatments on the $488-\mathrm{D}$ basin..............................

Figure 22. Soil moisture in the control plots as measured by the ADCON sensors...37

Figure 23. Soil moisture in the Ash, Topsoil and Control plots as measured by the ADCON sensors....................................................38

Figure 24. Comparison of the TRIME TDR measurement and gravimetric water content for sediments taken during several sampling events and at various depths on the 488-D basin

Figure 25. Soil moisture content and response to a rain event as detected by the ADCON sensor at various soil depths on topsoil and control plots at the 488-D basin. 


\section{EXECUTIVE SUMMARY}

The 488-D Ash Basin is an unlined containment basin that received ash and coal reject material from the operation of a powerhouse at the USDOE's Savannah River Site, SC. The pyritic nature of the coal rejects has resulted in the formation of acidic drainage (AD), which has contributed to groundwater deterioration and threatens biota in down gradient wetlands. Establishment of a vegetative cover was examined as a remedial alternative for reducing $\mathrm{AD}$ generation within this system by enhanced utilization of rainwater and subsequent non-point source water pollution control. The low nutrient content, high acidity, and high salinity of the basin material, however, was deleterious to plant survivability. As such, studies to identify suitable plant species and potential adaptations, and pretreatment techniques in the form of amendments, tilling, and/or chemical stabilization were needed. A randomized block design consisting of three subsurface treatments (blocks) and five duplicated surface amendments (treatments) was developed. The three blocks included: (A) ripped and compost amended, (B) ripped only, and (C) control. Surface treatments were applied randomly to two $15 \times 15 \mathrm{~m}$ plots within each block. Treatments included: 1) $10-15 \mathrm{~cm}$ topsoil, 2) $10-15 \mathrm{~cm}$ bottom ash, 3) 10-15 $\mathrm{cm}$ flyash/wood mulch blend, 4) apatite (5 kg/ha), and 5) control. One hundred inoculated pine trees were planted on each plot. Herbaceous species were also planted on half of the plots in duplicated $1-\mathrm{m}^{2}$ beds. After two growing seasons, deep ripping, subsurface amendments and surface covers were shown to be essential for the successful establishment of vegetation on the basin. Loblolly and Virginia pine seedlings inoculated with the ectomycorrhizal fungi Pisolithus tinctorius $(\mathrm{Pt})$ and Scleroderma cepa $(\mathrm{Sc})$ withstood the harsh environment of the 488-D basin and grew to levels that exceeded those on an uncontaminated site during the study period. Seedlings located on Block A (ripped and deep amended) in the topsoil plots developed a root system that grew into the basin media without significant adverse effects to the plant. These trees showed no significant nutrient deficiency problems. Trees growing in the flyash and mulch plots of Block A achieved a survival rate greater than $50 \%$, but tissue analysis indicated a potential problem due to boron toxicity. Seedlings on Blocks B and C, regardless of the surface treatment, were influenced by lack of subsurface amendments and ripping, respectively, which resulted in poor rooting conditions, high acidity and high mortality. A prolonged regional drought may have contributed to these results by a higher than expected mortality rate in all Blocks due to desiccation and changes to the chemistry of the basin by evaporative salt formation and subsequent acid generation. Water samples from lysimeters in Block $\mathrm{C}$ and in the deeper profile reflected this phenomenon with high acidity, $\mathrm{Fe}, \mathrm{Mn}, \mathrm{Al}$, sulfate and trace element concentrations. Water quality characteristics of the topsoil plots in Block A were acceptable as was demonstrated by the good growth and survival rates on these plots. The overall influence of the vegetation on water quality and quantity is difficult to ascertain at this time because the system is still immature. A general decrease in soil moisture content, however, was measured in the rooting zone of plots that were successfully vegetated (Block A - topsoil), which suggests that the potential exists for considerable utilization of water by a vegetative cover. 


\section{INTRODUCTION}

The degradation of water resources from coal mining and coal combustion activities is widespread throughout the United States. Acidic drainage (AD), a low $\mathrm{pH}$ water enriched with iron, aluminum, sulfate, heavy metals and trace elements (e.g., lead, selenium, arsenic, mercury, zinc) is formed upon exposure of pyrite to the oxidizing forces of air and water. Pyrite $\left(\mathrm{FeS}_{2}\right)$, the most common sulfide mineral on Earth, is often found within coal seams and their associated geologic strata. Once disturbed or extracted during the mining process, pyrite oxidation and $\mathrm{AD}$ generation may begin and can continue for thousands of years. Moreover, since pyrite is found within the coal seam, AD is not solely a "mining" problem and may occur anywhere that pyrite enriched coal or its byproducts are stored. It has been estimated that approximately 20,000 km of streams and rivers are impacted by AD in the United States (Kleinmann, 1989).

The oxidation of sulfide minerals and formation of $\mathrm{AD}$ is a complex process involving hydrolysis, redox, and microbial reactions (Nordstrom, 1986). The general stoichiometry can be described by the reaction:

$$
\mathrm{FeS}_{2(\mathrm{~s})}+3.75 \mathrm{O}_{2}+3.5 \mathrm{H}_{2} \mathrm{O} \leftrightarrow \mathrm{Fe}(\mathrm{OH})_{3(\mathrm{~s})}+2 \mathrm{H}_{2} \mathrm{SO}_{4} \text {, }
$$

where iron sulfide and other mixed-metal sulfides decompose upon exposure to the atmosphere, producing sulfuric acid and insoluble ferric iron hydroxide from hydrolysis. Subsequently, the sulfuric acid can dissolve and mobilize metals from materials in the surrounding environment (coal, ash, soil etc.). Conventional practices for the treatment of $\mathrm{AD}$ require the addition of highly alkaline chemicals such as sodium hydroxide, calcium hydroxide, calcium oxide, sodium carbonate or ammonia. These reagents efficiently promote metal removal (via precipitation) and acidity neutralization. However, chemical treatment is a long-term endeavor that requires continual support for reagents, personnel and facilities.

In an effort to curtail these costs and prevent water pollution, several innovative techniques have been proposed that may reduce $\mathrm{AD}$ generation by limiting the exposure of pyrite to air and water through biological means. An oxygen cover is one such technology that utilizes a layer of compost or other organic material (peat, hay, straw, sawdust) above the mining waste to deplete oxygen through bacterial consumption (Pierce et al., 1994). The organic waste may also inhibit oxidation by removal of $\mathrm{Fe}^{3+}$ (an oxidizer) from solution through complexation, and the formation of pyrite- $\mathrm{Fe}^{2+}$-humate complexes (Evangelou, 1995). Changes in the particle size distribution of the cover over that of the mining waste may also be engineered to enhance water storativity. As such, water percolation through the waste and exposure to the pyrite could be decreased. Under such a scenario, the use of vegetation may also be included to aid in the removal of water through evapotranspiration (Dobson et al., 1993). On a large scale, the net effect of these techniques is to cut off the oxygen source. On a microscopic scale, these techniques may also aid in preventing oxidation by altering the surface chemistry of pyrite. Several researchers have shown that soluble organic acids from the breakdown of litter, and colloidal silicate and phosphate salts from soils may act as passivating agents through the 
formation of a coating on the surface of the crystal, which may render it impenetrable to oxidative attack (Lalvani et al., 1989; Evangelou, 1995; Belzile et al., 1997).

\section{Vegetative Cover Study}

The 488-D Ash Basin is an unlined, earthen basin that contains approximately one million tons of dry ash and coal reject material at the U.S. Department of Energy's Savannah River Site. The pyritic nature of the coal rejects has resulted in the formation of $\mathrm{AD}$, which has contributed to groundwater deterioration and threatens biota in down gradient wetlands. Establishment of a vegetative cover, as described above, is being examined as a remedial alternative for reducing $\mathrm{AD}$ generation within this system. Prior to initiating the study, the basin supported little vegetation, contained a highly compacted surface that promoted water runoff, and exhibited a hydrology that was controlled primarily by precipitation input and loss through evaporation and seepage (Figure 1).

\section{Evapotranspiration Cover}

\section{Cross Section - 488-D Ash Basin Pre-Treatment}

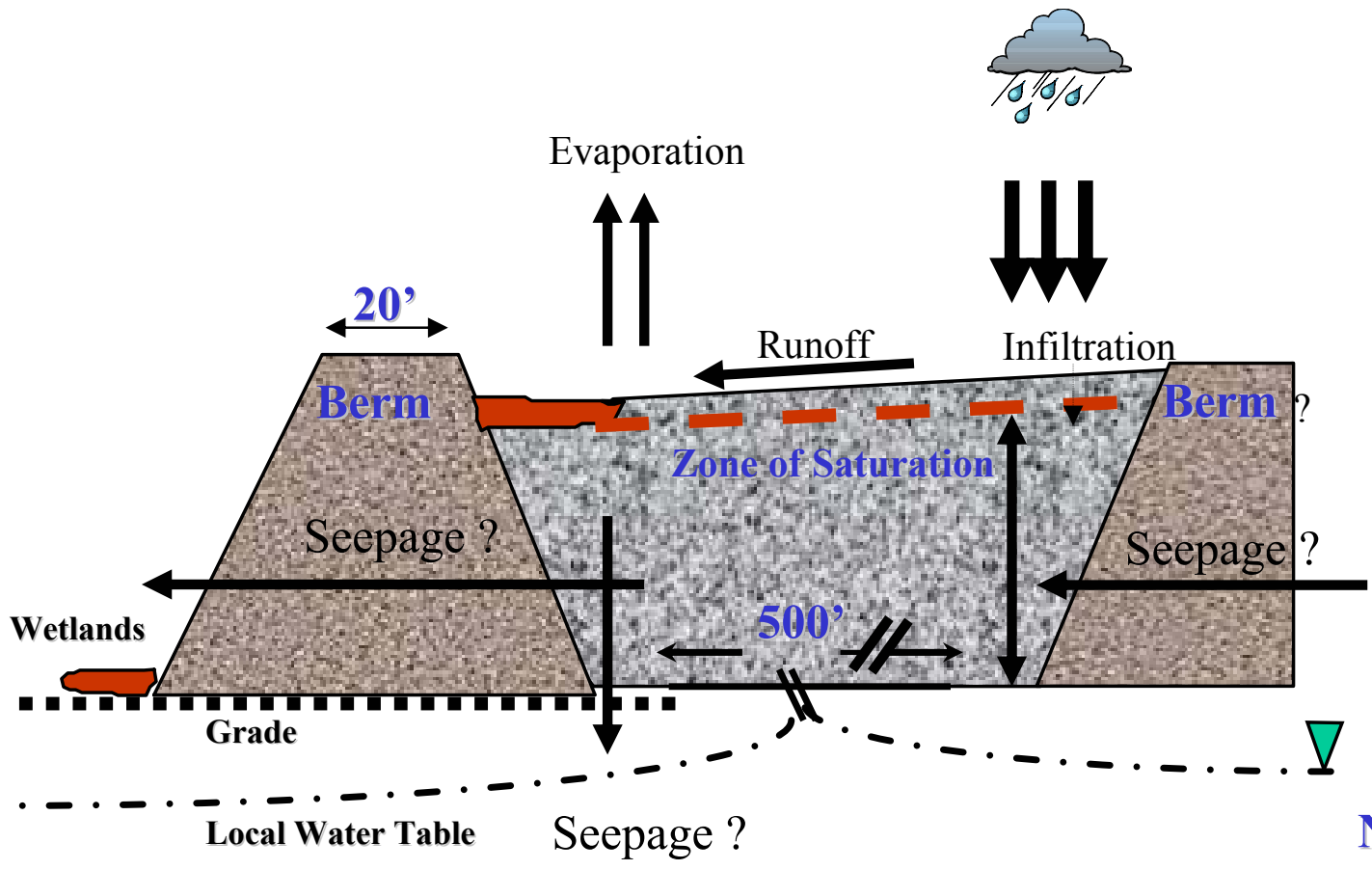

Figure 1. Conceptual cross-section of the 488-D basin prior to vegetative cover establishment. 
Low permeable clays within the walls and floor of the basin limit seepage and have contributed to the development of a fluctuating semi-saturated zone within the fill material. Establishment of a vegetative cover may be created by breaking the compacted surface through mechanical means; adding a suitable cover material to support vegetation and store rainwater; and planting vegetation species that are suitable for growth in the media, and can potentially grow into the ash/reject material (Figure 2).

\section{Evapotranspiration Cover Cross Section - 488-D Ash Basin $\mathbf{T}=2$ Years}
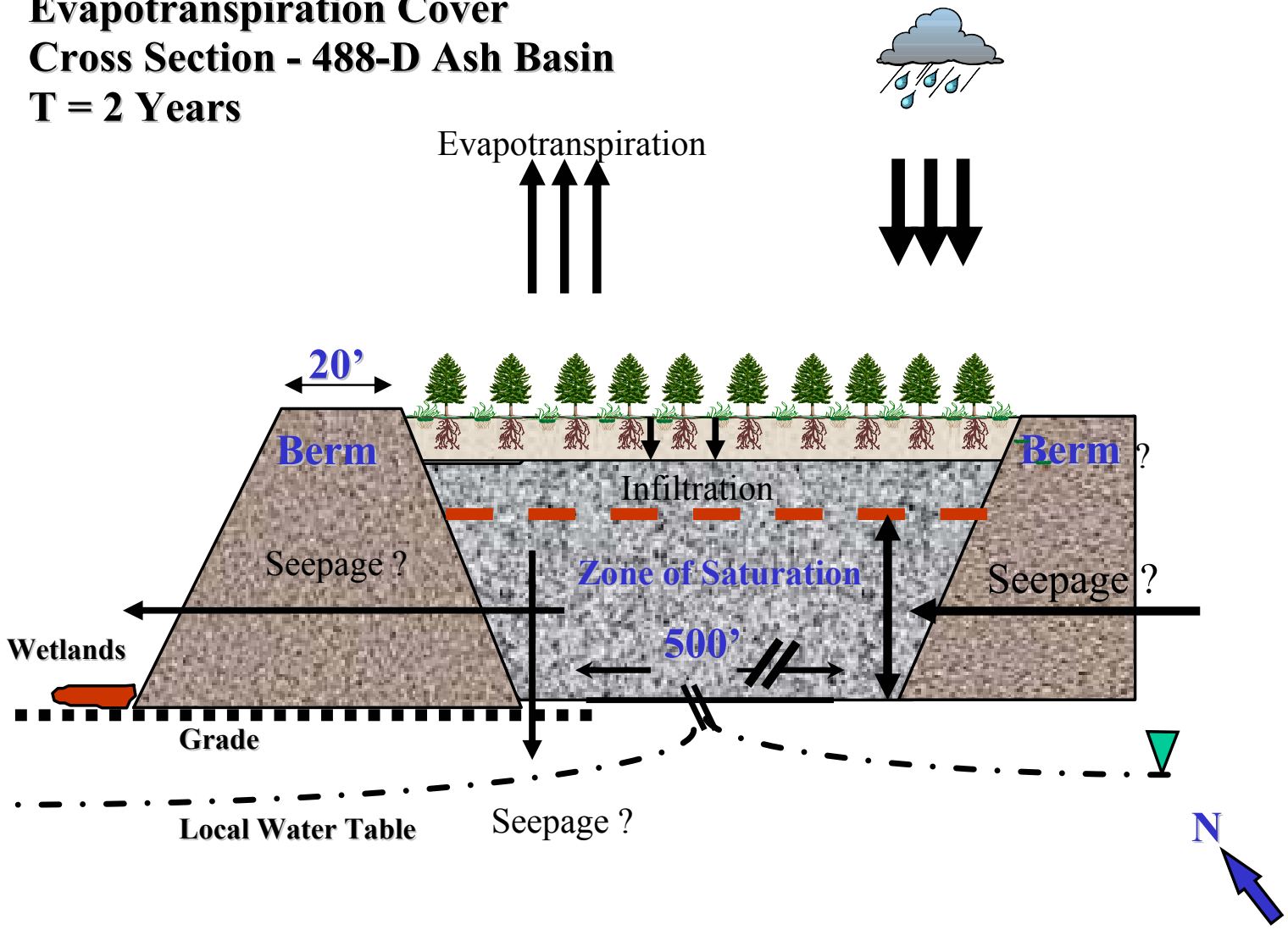

Figure 2. Conceptual cross-section of the 488-D basin two years after vegetative cover establishment.

Ultimately, a mature closed-canopy forest shall be established with a dense rooting mass that will intercept and utilize rainwater, minimize infiltration, and alter the electrochemical conditions within the waste material such that pyrite oxidation is prevented (Figure 3). The forested cover may also reduce or eliminate annual maintenance associated with standard RCRA covers. 


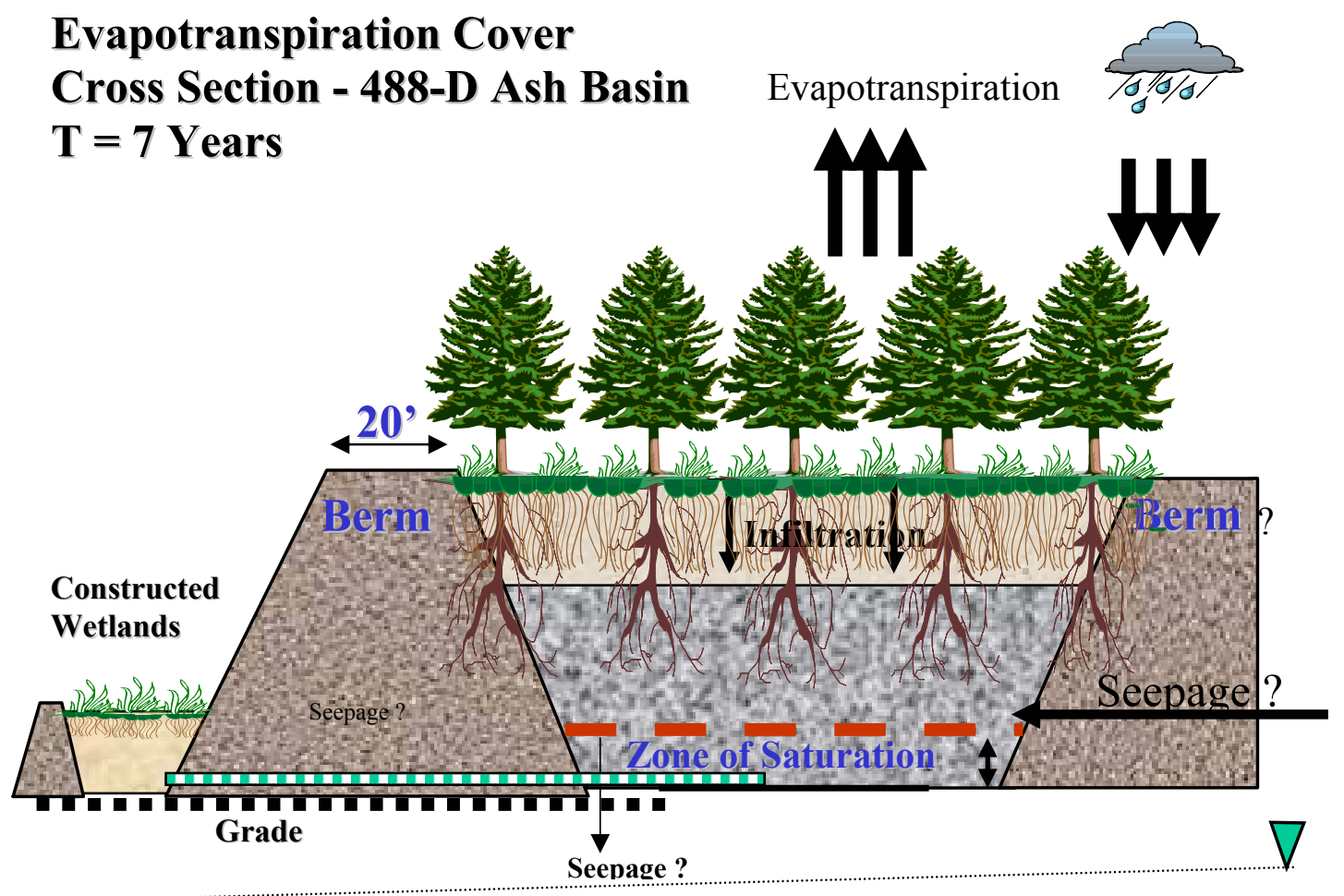

Local Water Table

Figure 3. Conceptual cross-section of the 488-D basin 7 years after vegetative cover establishment.

The low nutrient content, high acidity, and high salinity of the basin material, however, is inhibitive to most plants. As such, studies to identify suitable plant species and potential adaptations, and pretreatment techniques in the form of amendments, tilling, and/or chemical stabilization were needed. Given these conditions, laboratory, greenhouse, and field experiments were conducted to identify parameters that may lead to the successful deployment of a vegetative cover on the 488-D reject coal basin.

\section{MATERIALS AND METHODS}

\section{Site Description and Background}

The 488-D ash basin is an unlined, earthen containment basin located on the Savannah River Site, SC that received sluiced fly ash, dry fly ash and coal reject material from the early 1950's to the mid 1990's . Non hazardous wastes deposited in the basin contain metals typical of fly ash and coal (As, Co, Cr, Cu, Fe, Mn, Ni and $\mathrm{Zn}$ ). The ash basin is $\sim 1,800^{\prime} \times 600^{\prime} \times 18^{\prime}$ in size and contains $\sim 19 \times 10^{6} \mathrm{ft}^{3}$ of waste material. The basin was constructed on the existing land surface at $\sim 35 \mathrm{~m}$ (msl) and is $\sim 9 \mathrm{~m}$ above the Savannah River. The present surface of the basin is at $\sim 40$ to $37^{\prime}$ (msl), sloping gently to the west and it is filled with waste, except in the far western reach where surface waters collect during rainfall events. 
The extent of water-saturated material in 488-D is not known, nor if any communication exists between basin waste and the local water table. Based on limited soil borings, the waste seems to be variably saturated, having both wet and dry zones that vary with depth. The source of this water may be meteoric infiltration or lateral groundwater flow from adjacent basins (488-1D, -2D and -4D). Hydraulic anisotropies may have been created when various materials were introduced to the basin. Alternatively, post-depositional features such as diagenetic "hard pans" may have developed as materials weathered over time, creating local anisotropies.

\section{Greenhouse Study}

Greenhouse studies were initiated to evaluate potential amendments and/or treatments required for plant growth in the extremely acidic $(1: 1 \mathrm{pH} \approx 2.0)$ basin material. Treatments included the use of passivating agents to inhibit pyrite oxidation; and mycorrhizal fungi to enhance plant nutrient and water absorption, and promote feeder root health and longevity. Forty-eight gravity lysimeters were packed with $4 \mathrm{Kg}$ of airdried coal reject material and amended with $4 \mathrm{Kg}$ of either coal reject material (control); 1:1 coal reject/ fly ash mixture; or 2:1:1 coal reject/topsoil/compost mixture. Eight lysimeters from each group were leached with one pore volume of either a dilute $\mathrm{H}_{2} \mathrm{O}_{2} / \mathrm{KH}_{2} \mathrm{PO}_{4} / \mathrm{NaOAc}$ solution or distilled water. Thereafter, all lysimeters were leached weekly with 0.25 pore volumes of distilled water. After leaching was initiated, one-half of the lysimeters were inoculated with vesicular-arbuscular mycorrhizae (VAM) (four per treatment/amendment pair). Subsequently, all lysimeters were planted with a $5 \mathrm{x}$ $5 \mathrm{~cm}$ plug of bahiagrass (Paspalum notátum). Plant survival and growth characteristics were monitored for a period of nine months following transplanting.

Seventy-two loblolly pine (Pinus taeda) seedlings were also evaluated in pots containing a 1:1 mixture of basin material and a commercially available compost material (Carolina compost) made from municipal biosolids, poultry litter and wood chips. Half (36) of the seedlings were inoculated with Pisolithus tinctorius (Pt) ecto-mycorrhizae, while the other half remained as non-inoculated controls. The seedlings were watered daily for three months. Survival and growth characteristics were monitored on a weekly basis during this period.

\section{Field Study}

A randomized block design consisting of three subsurface treatments (blocks) and five duplicated surface amendments (treatments) was developed for the 488-D basin (Figure 4). Subsurface blocks were established to evaluate the influence of compaction and nutrient loading on plant survival and root penetration in the basin material. The three blocks included:
A. Disturbed (ripped and disked) and compost amended (60 wet ton/acre Carolina compost),
B. Disturbed (ripped and disked) with no compost amendment,
C. Undisturbed (no ripping, or disking). 
The five surface treatments outlined below were applied randomly to 2 of the 10 plots within each of the above three blocks:

1. Control (no additional amendments or mechanical treatment applied).

2. Apatite and super triple phosphate,

3. Topsoil cover $(10-15 \mathrm{~cm})$,

4. Ash/compost blend cover $(10-15 \mathrm{~cm})$,

5. Ash alone cover $(10-15 \mathrm{~cm})$ (from A-area powerhouse),

Each block was approximately 0.5 hectares in size. Each treatment covered a surface area of $232 \mathrm{~m}^{2}$. Five meter buffer strips were situated between each treatment cell. The purpose of (1) was to replant Pt-pine under the existing conditions within each block without further treatment. The purpose of (2) was to assess the impact of a passivating agent independent of a cover. The apatite provides a source of phosphate that can (a) form $\mathrm{Fe}(\mathrm{III})$ (a pyrite oxidizer) - $\mathrm{PO}_{4}$ precipitates, (b) form a Fe-phosphate surfacecoating on the pyrite surface to limit oxygen diffusion, and (c) act as a weak base to raise $\mathrm{pH}$ and further limit Fe(III) availability. The $10-15 \mathrm{~cm}$ soil covers $(3,4,5)$ were utilized to first; reduce the diffusion of oxygen to the pyrite particles, second; to reduce upward movement of salts by surface evaporation, and third; to provide a minimal soil media for tree and grass root growth. None of the covers were incorporated with the basin material.

488D Vegetative Cover - Plot Layout

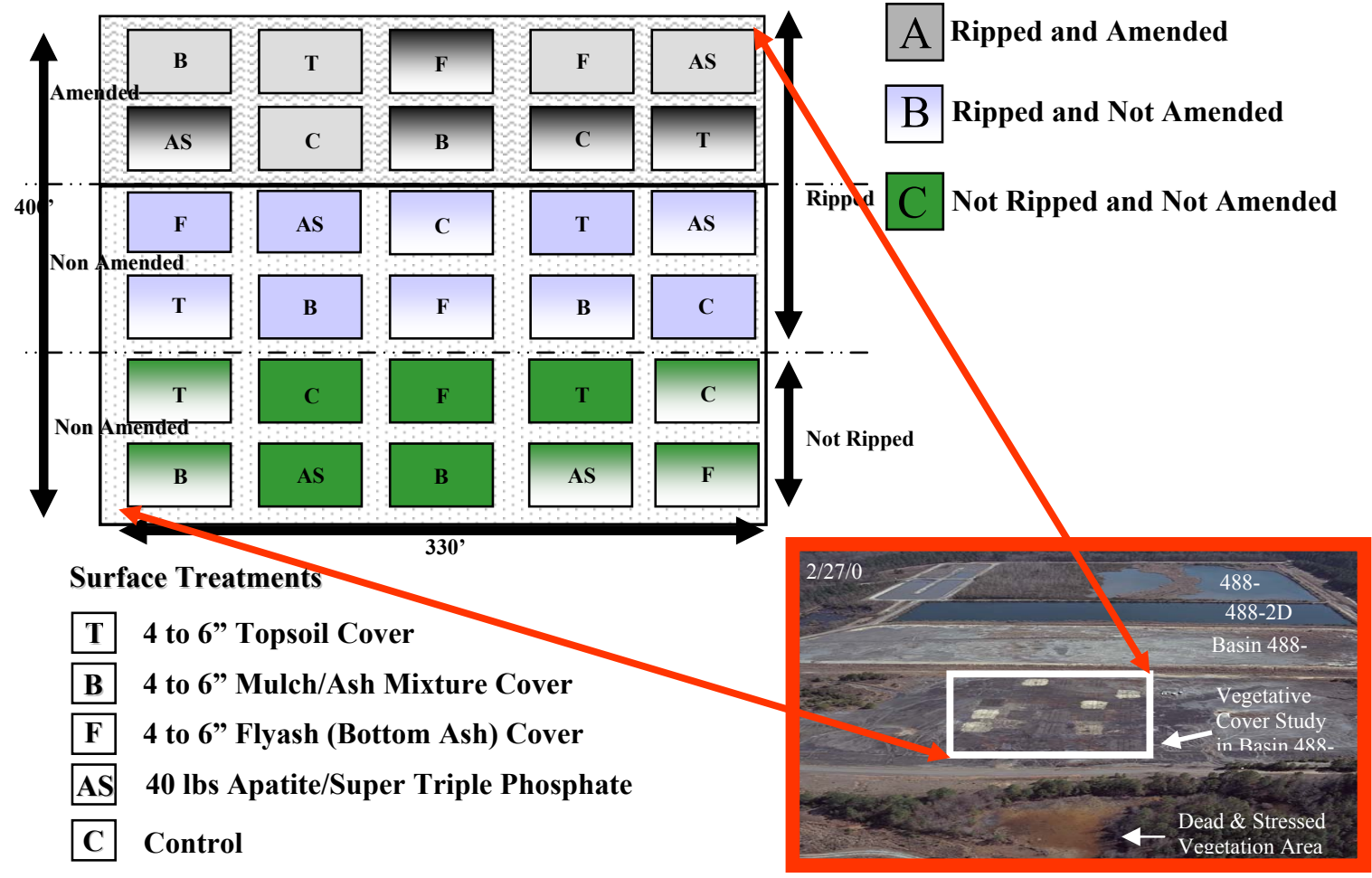

Figure 4. Plot layout on the 488-D basin. 
Site preparation began in December, 1999 with the application of sixty wet tons per acre of Carolina compost to Block A. Subsequently, Blocks A and B were ripped to a depth of nearly one meter, then plowed with a cutting harrow. All tillage implements were pulled with dozers to minimize additional compaction. Soil samples were collected from the surface $(0-15 \mathrm{~cm})$ in triplicate from each treatment plot in April and September of 2000 and analyzed for $\mathrm{pH}(1: 1)$. Results indicated that the ripping and the addition of the compost had an acidifying effect on the surface material (Figure 5). To partially neutralize the high surface acidity, ten tons per acre of agricultural lime $\left(\mathrm{CaCO}_{3}\right)$ was broadcast over the entire study area in October of 2000. Surface amendments were applied from November 2000 thru January 2001. Approximately 40 tons of topsoil, mulch mixture, and ash were dumped on their respective plots, then leveled using a frontend loader. Apatite and super triple phosphate were applied to their respective plots at a rate of 3 pounds of $P$ per acre using an ATV mounted fertilizer spreader.

\section{8-D Basin Surface pH}
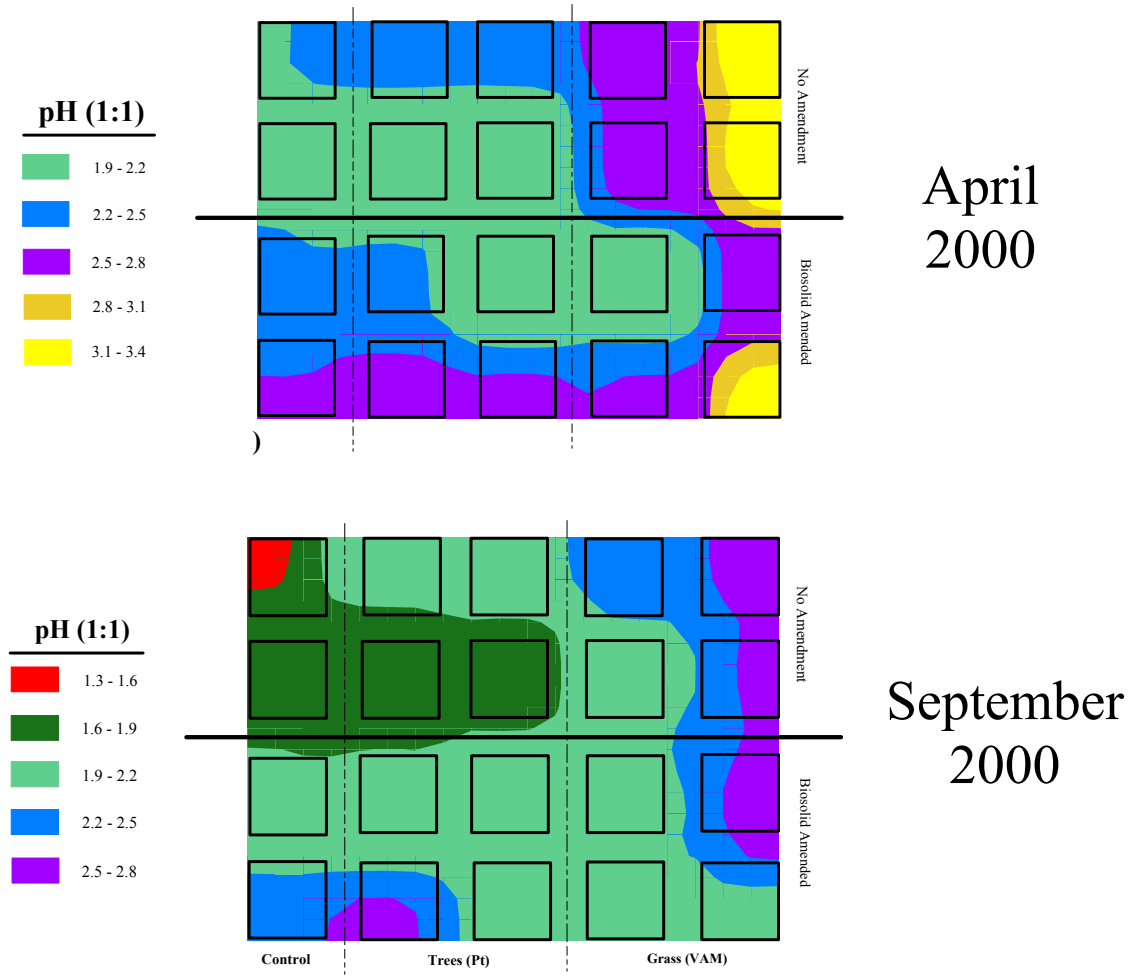

Figure 5. Surface $\mathrm{pH}(1: 1)$ prior to (April) and after (September) tillage.

Prior to the cover application, samples were collected from each of the materials and the basin. The samples were analyzed for $\mathrm{pH}, \mathrm{EC}$, total recoverable metals (USEPA, 1994, Method 200.2); total exchangeable bases and nitrate (NRCS, 1996); and total N, and C following methods outlined in the Methods of Soil Analysis (Sparks, et al., 1996). After 
the amendments had been applied, additional soil samples were collected in triplicate from each plot at depths of $0-10 \mathrm{~cm}$ and $40-50 \mathrm{~cm}$. These samples were analyzed for pH, EC, total recoverable metals (USEPA, 1994, Method 200.2); total N and C using methods outlined in the Methods of Soil Analysis (Sparks, et al., 1996). Samples for metal analysis were digested using the $\mathrm{HCl} / \mathrm{HNO}_{3}$-based microwave digestion method (USEPA, 1996) followed by inductively coupled plasma-mass spectrometry or optical emission spectrometry (ICP-MS, ICP-OES). Quality assurance-quality control protocols were followed for all analytical procedures as outlined in USEPA Method 6020 (USEPA, 1994). Additional soil samples were collected from each plot at depths of $0-10 \mathrm{~cm}$ and $40-50 \mathrm{~cm}$ after one year and analyzed for $\mathrm{pH}$ and $\mathrm{EC}$.

Containerized loblolly and Virginia (Pinus virginiana) pine seedlings inoculated with Pisolithus tinctorius $(\mathrm{Pt})$ and Scleroderma cepa $(\mathrm{Sc})$ were planted at the Creech Nursery (Wedgefiels, SC) in May 2000 as a seedling source for the 488-D basin. An assessment of the seedlings in November 2000 indicated good growth characteristics and ectomycorrihizal development (Table 1). A late season frost, however, injured some of the seedlings and an alternate source of bare root loblolly pine was obtained from a nursery in Tennessee. The seedlings were transplanted on the basin in February 2001. Mechanical tree augers were used to create a hole for tree placement. The hole was dug to a depth where direct contact between the plant roots and the basin material was achieved. Each plot received 100 trees on a 1.5-meter spacing. A planting scheme was developed to evaluate the differing seedling species and stock. All treatment plots received three rows (30 seedlings) of containerized Pt loblolly; five rows ( 50 seedlings) of bare root loblolly with a damaged Pt containerized seedling in the same hole to serve as an inoculant for the bare root tree; and either two rows (20 seedlings) of Pt Virginia pine, or the bare root loblolly mix. A total of 3000 seedlings were planted in the study area. Three additional plots of 100 seedlings, one on each edge of the basin and another on native soil, were established to evaluate seedling survival and growth characteristics outside of the primary study area.

Table 1. Mean ectomycorrhizal index for 488-D containerized seedlings.

\begin{tabular}{llcccc|}
\hline Seedling Type & Pt & Sc* & Other & Total \\
\hline Loblolly pine & $38.5 \pm 9.4$ & $23.0 \pm 9.8$ & $5.0 \pm 0$ & $66.0 \pm 9.4$ \\
Virginia pine & $37.1 \pm 9.5$ & $30.0 \pm 8.2$ & $5.0 \pm 0$ & $72.1 \pm 2.7$ \\
\hline $\begin{array}{l}\text { †isolithus tinctorius } \\
* \text { Scleroderma cepa }\end{array}$
\end{tabular}

Growth and survival characteristics were monitored throughout the study period. Seedling survival was evaluated each month for all trees planted. A subset of seedlings representing each stocking unit were identified, tagged, and were used to evaluate longterm growth characteristics. Seedling height and stem diameters were measured on these selected plants in April 2001, October 2001 and October 2002. Plant root growth (depth and spread), plant biomass and inoculation index were evaluated after one growing season using methods outlined by Grand and Harvey (1982). Plant tissue samples were collected and analyzed for total elemental concentration using the $\mathrm{HCl} / \mathrm{HNO}_{3}$-based microwave digestion method (USEPA, 1996) followed by inductively coupled plasma- 
mass spectrometry or optical emission spectrometry (ICP-MS, ICP-OES). Tissue samples were also analyzed for nutrient content using the wet ash $\mathrm{HNO}_{3}+\mathrm{H}_{2} \mathrm{O}_{2}$ procedure (Ellis et al., 1992).

Pensacola bahiagrass, crown vetch (Coronilla varia), and red clover (Trifolium pratense) were grown in the greenhouse at SREL for use on the 488-D basin. The grass and legume species were seeded in flats that contained either a commercially available potting soil, or a potting soil inoculated with vesicular-arbuscular mycorrhizea (VAM). Six 1 x 1 meter subplots were established on one-half of the treatment plots on the basin, representing each treatment of each block (Figure 6). Each subplot received twenty 5 x $5 \mathrm{~cm}$ plugs of a grass or legume, with and without VAM in May 2001. The transplants were watered immediately after planting, but received no additional irrigation afterwards. Survival and biomass measurements were performed on an annual basis for these species. Additional grass and weed species that were derived from the seed bank of the treatment amendments, or naturally seeded, were evaluated for biomass and species richness during the first growing season. Each plot that contained non-planted herbaceous vegetation was randomly sampled at three locations using 1x1 meter sample plots. All vegetation within the sample plot was identified by species, harvested, dried and weighed to obtain a measure of biomass. By the second growing season, naturally seeded grasses and weeds had become a nuisance and posed a significant threat to the planted seedlings by competing for resources (water and nutrients). As such, all plots were mowed between the seedling rows during the second growing season and measurement of the herbaceous component ceased.

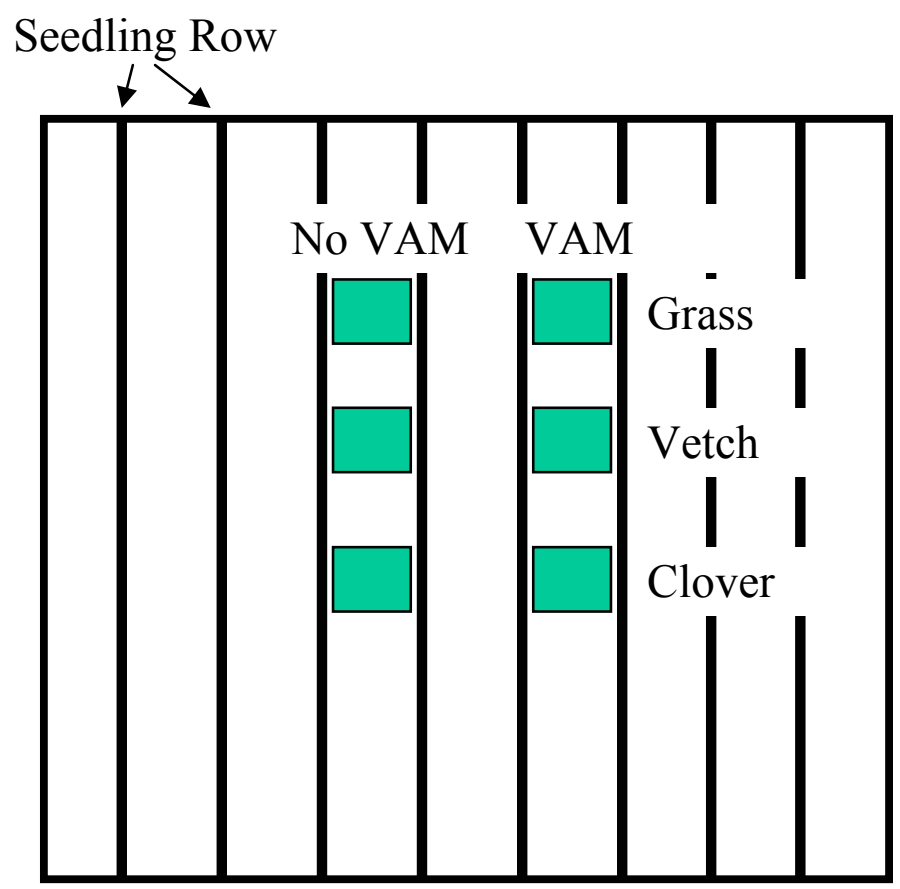

Figure 6. Herbaceous plot layout. 


\section{Hydrology and Soil Moisture Monitoring}

Basin hydrology was monitored each month using a combination of piezometers, lysimeters, and water level gages. Each block contained a sampling nest comprised of a shallow monitoring zero-tension lysimeter at a depth of $200 \mathrm{~cm}$ and three piezometers at 50,100 , and $200 \mathrm{~cm}$ depths (Figure 7). Piezometers were constructed of $2.5 \mathrm{~cm}$ diameter schedule $80 \mathrm{PVC}$ pipe with perforations drilled at the submerged end and covered with geofabric. Borings for the piezometers were drilled by hand using a $8.5 \mathrm{~cm}$ bucket auger. Washed sand was packed from the base of the borings to approximately $25 \mathrm{~cm}$ above the screened area and the remaining annulus was filled to just below the surface with a slurry created from the bore cuttings. A plug of bentonite was placed at the surface to prevent short-circuiting. Shallow zero-tension lysimeters were constructed in a similar fashion using $5.0 \mathrm{~cm}$ diameter schedule $40 \mathrm{PVC}$ pipe that was slotted along its entire length. Water depths within the lysimeter and piezometers were measured using a portable water level indicator. A semi-continuously recording data logger (WL-80 ${ }^{\circledR}$, Remote Data Systems) was installed to record hourly variations in vadose zone saturation. Groundwater depth, and piezometric surface shall be determined from measurements accumulated with the above monitoring devices.

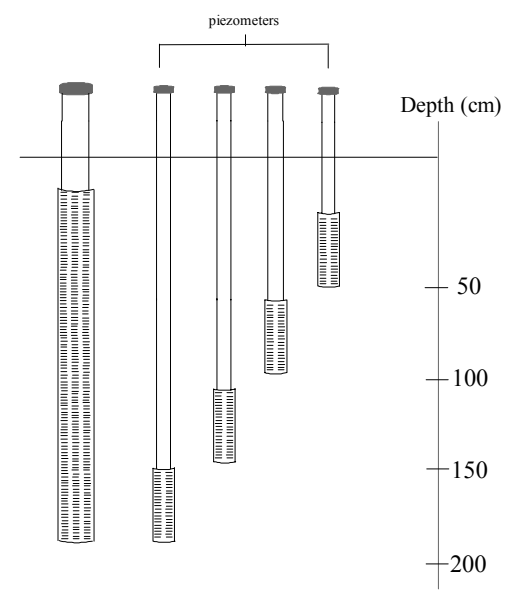

Figure 7. Schematic of well and piezometer cluster. 
Open precipitation and event logging was measured using a $\mathrm{HOBO}^{\circledR}$ data logging rain gauge. Other meteorological variables (net solar radiation, air temperature, humidity, wind speed) were measured at the $\mathrm{N}$-area weather tower. Soil moisture at $25 \mathrm{~cm}$ intervals, to a depth of 2 meters, was determined in Block A on the ash and topsoil treatments; outside the study area in a non vegetated area (control); and in an area that contained naturally established vegetation (reference site, Short Rotation Woody Crop experimental site), using time-domain (TDR) (TRIME-FM ${ }^{\circledR}$, IMKO GmbH) and frequency-domain (FDR) (ADCON ${ }^{\circledR}$ Instruments) reflectometry. Soil compaction was evaluated using a cone penetrometer to assess drainage characteristics (Farnell A2451). Soil temperature was monitored using $\mathrm{HOBO}^{\circledR}$ data logging temperature sensors. Temperature loggers were placed $10 \mathrm{~cm}$ below the surface in plots representing each cover type, control and in the vegetated area on the east corner of the basin.

\section{Water Quality}

Surface water samples were collected bi-weekly from three locations during the period June 1999 to September 2000 and again in June of 2001 and 2002. The sample locations were: ponded area at the west end of the basin, pipe leak at the west berm of basin, and the stressed and dead vegetation area adjacent to the north berm. Subsurface water samples from the basin were collected on a quarterly basis using lysimeters. Suction (tension) lysimeters at 15 , and $30 \mathrm{~cm}$ depths were installed in several treatment groups. An additional sampler at $200-\mathrm{cm}$ was installed in each block near the piezometer clusters. Lysimeter placement involved coring a $5 \mathrm{~cm}$ diameter hole to the desired depth using a bucket auger. A slurry was formed from a portion of the excavated soil, then poured into the hole where the lysimeter rests, such that the porous ceramic cup on the sampler is completely surrounded by the mixture. The remaining area above the slurry was backfilled with the original soil and firmly tamped to prevent short circuiting. A plug of bentonite clay was placed around the lysimeter to further prevent preferential flow of water in the backfilled area. Once installed, a vacuum of 60 centibars was applied to the lysimeter using a hand vacuum pump. A stopper assembly equipped with a neoprene tube and pinch clamp was utilized to contain the applied vacuum. Water samples were extracted from the lysimeters by disconnecting the stopper assembly, installing a handcrank peristaltic pump, and pumping the collected water into polyethylene bottles.

Field measurement of $\mathrm{pH}$ and electrical conductivity was performed using a HYDROLAB ${ }^{\circledR}$. Water samples were packed in ice and transported to laboratory refrigerators where they remained at $4^{0} \mathrm{C}$ until analyzed. Prior to analysis, samples were passed through a $0.45 \mu \mathrm{m}$ filter and preserved as deemed necessary according to procedures in the Standard Method for the Examination of Water and Wastewater (APHA, 1989). Analysis of the water samples was also performed using procedures outlined in the Standard Method for the Examination of Water and Wastewater (APHA, 1989). 


\section{Calculating Evapotranspiration}

Mean daily reference evapotranspiration rates were calculated using a modified version of the Penman-Monteith equation (Monteith, 1965; Allen et al., 1999) with fixed parameters derived from the literature (Walter et al., 2000 and Itenfisu et al., 2000.). The equation used was:

$$
E T_{\text {ref }}=\frac{0.408 \Delta\left(R_{n}-G\right)+\gamma \frac{C_{n}}{T+273} u_{2}\left(e_{s}-e_{a}\right)}{\Delta+\gamma\left(1+C_{d} u_{2}\right)}
$$

where $\mathrm{D}$ is the slope of the saturation vapor pressure at the mean air temperature $\left(\mathrm{kPa}^{\circ} \mathrm{C}^{-}\right.$ $\left.{ }^{1}\right), R_{n}$ and $G$ are the net radiation and soil heat flux density $\left(\mathrm{MJ} \mathrm{m}^{-2} \mathrm{~h}^{-1}\right)$, $\mathrm{g}$ is the psychrometric constant $\left(\mathrm{kPa}^{\circ} \mathrm{C}^{-1}\right), T$ is the hourly mean temperature $\left({ }^{\circ} \mathrm{C}\right), u_{2}$ is the hourly mean wind speed in $\mathrm{m} \mathrm{s}^{-1}$, and $e_{s}-e_{a}$ is the vapor pressure deficit $(\mathrm{kPa})$. The coefficients in the numerator $\left(C_{n}\right)$ and the denominator $\left(C_{d}\right)$ were given specific values depending on the reference crop of concern (Allen et al., 1999). Values for $C_{n}$ vary depending upon the type of crop due to aerodynamic resistance differences and physiological functions in relation to water usage.

Inputs into the equation were obtained from weather data measured at a station located on the 488-D basin. Inputs included were the daily mean solar radiation ( $\left.\mathrm{MJ} \mathrm{m}^{-2} \mathrm{~d}^{-1}\right)$, air temperature $\left({ }^{\circ} \mathrm{C}\right)$, wind speed $\left(\mathrm{m} \mathrm{s}^{-1}\right)$, and humidity $(\%)$. The latitude, longitude and elevation of the basin were utilized to determine constants for the equation as outlined by Allen et al. (1998). The Hargreaves-Samani equation (1985) was also used to determine ET by temperature conditions only.

A modeling exercise was performed to evaluate potential evapotranspiration on the basin under the various growing schemes using climatic data from the weather station located on the basin. For the purposes of this exercise the following terms were utilized to describe both the reference condition and the calculated differences as a result of cropping and site specific constraints on the evapotranspiration demand. Note: for clarity, the terminology listed below varies slightly from that described by the American Society of Civil Engineers (ASCE). However, all Penman-Monteith ET calculations conform to those recommended by the ASCE (Walter et al., 2000).

- $E T_{o}$ - Reference $E T$ for a grass crop with sufficient moisture (wetted) and limited environmental stress with an approximate height of $0.12 \mathrm{~m}$.

- $E T_{\text {ref }}$ - Reference $E T$ for the various crops modeled on the basin with adjustments (cropping coefficients) for light absorption by the canopy, canopy roughness, crop physiology, and surface wetness. In addition, adjustments for soil salinity levels in excess of $2 \mathrm{dS} \mathrm{cm}^{-1}$ were employed. Adjustments for root-zone depletion of available water due to the drought were not applied due to the inaccuracy of data from the Adcon FDR system and subsequent loss of hourly soil moisture conditions. 
- $\operatorname{PnET}_{(\mathrm{N}-\text { area) }}$ - Reference $E T$ for a forested stand with sufficient moisture (wetted) and limited environmental stress. Estimates were calculated using input variables from the $\mathrm{N}$-area weather station.

- ETo (D-area) - Projected reference ET for a "healthy" grass crop on the 488-D basin with an approximate height of $0.12 \mathrm{~m}$ and limited environmental stress. Estimates were calculated using input variables from the D-area weather station.

- ETref $_{\text {(grass) }}$ - Projected reference $E T$ for the current grass and tree crop (i.e. topsoil plot) on the 488-D basin exhibiting approximately $50 \%$ cover and adjusted for high salinity (8\% reduction in ET due to salt) (Allen et al., 1998). Estimates were calculated using input variables from the D-area weather station. Note: independent calculations for the current tree condition alone were not calculated because canopy closure had not occurred and incident light penetration through the canopy was too high (i.e. leaf area index (LAI) calculations were no different than that of bare soil).

- ETref $_{\text {(trees) }}$ - Projected reference $E T$ for a closed-canopy pine forest (tree height $=$ 10 meter) on the 488-D basin exhibiting approximately $70 \%$ surface coverage and an herbaceous understory. Crop coefficients $\left(\mathrm{K}_{\mathrm{c}}\right)$ for this scenario varied from 1.01 to 1.15 depending upon the month of year (Allen et al., 1998; Snyder, personal communication). Estimates were calculated using input variables from the D-area weather station.

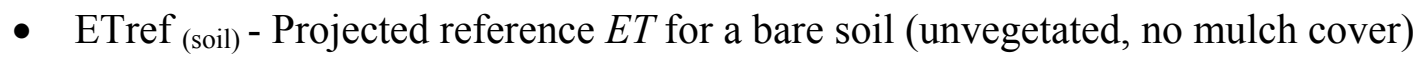
on the 488-D basin (i.e. control plot). Estimates were calculated using input variables from the D-area weather station following the methods of Stroonsnjider (1987). Estimate may be conservative and underestimate actual $E T$ if surface ponding of water occurs on the basin for a significant amount of time due to the low permeability of sediments.

- $\mathrm{ET}_{(\mathrm{HS})}$ - Projected reference $E T$ for a "healthy" grass crop on the 488-D basin with an approximate height of $0.12 \mathrm{~m}$ and limited environmental stress. Estimates were calculated using input variables from the D-area weather station and the Hargreaves-Samani equation.

\section{Gradient Study}

Two gradient amendment plots were established on the 488-D basin in 2001 to isolate the optimal depth needed for vegetation establishment. The plots were 10 meters wide by 60 meters in length and extended 0 to $50 \mathrm{~cm}$ in depth from end to end. The gradient material was primarily composed of the ash/compost mixture that was used on the vegetative cover study. One gradient contained only the ash/compost (B), while the other was mixed with approximately $20 \%$ topsoil (A). Prior to the amendment application, the site was ripped to a depth of $\approx 1$ meter at $\approx 1$ meter centers using a tractor equipped with a parabolic ripper. A portion of the material was dumped on the prepared site then ripped again. Finally, the remaining amendment was dumped and graded to the desired height using a road grader.

Loblolly pine seedlings inoculated with Pisolithus tinctorius and Scleroderma cepa, grown at the Creech Nursery, SC Forestry Commission in Wedgefield, SC, were planted 
in the gradient plots on December 14, 2001. Seedlings were placed 1 meter within and between each of four rows on the gradients. Each row contained 50 seedlings totaling 200 per plot and 400 for the entire study. By this arrangement, each seedling within a row differed by $\approx 1 \mathrm{~cm}$ of cover depth from end to end. Additional (50) seedlings were planted in native soil at the SRWC site for comparison and to monitor seedling health. Soil moisture on the plots was adequate at planting.

\section{Statistical Analysis}

General mean and standard error calculations for the replicate analyses were performed using Microsoft Excel. Analysis of variance (ANOVA), general linear models (PROC GLMs), and PROC Univariate were performed to determine significant differences in elemental composition of the harvested seedlings. Survival data of the seedlings (loblolly only) were analyzed with repeated measures logistic regression models (PROC GENMOD). The models included all main effects and two-way interactions, with survival as the dependent variable and subsurface (Block) and surface treatments (Cover) as the independent variables. Probabilities of seedling survival were calculated by back transformation of the least-squares mean (LSM) from the logistic models $\left(\mathrm{e}^{\mathrm{LSM}} /(1+\right.$ $\mathrm{e}^{\mathrm{LSM}}$ ). Seedling growth was estimated by subtracting the initial height (April, 2001) from the height at the end of the second growing season (October, 2002). Growth measures were analyzed with linear regression models (PROC MIXED). The models included all main effects and two-way interactions, with seedling growth as the dependent variable and subsurface and surface treatments as the independent variables. Due to the high mortality in control and apatite plots, and the loss of replication, statistical evaluation of the surface treatments was performed for the topsoil, ash and mulch treatments only. All statistical models were performed using SAS (SAS Institute Inc., 1999).

\section{RESULTS}

\section{Greenhouse Study}

Within two weeks after transplanting, all vegetation died in the non-amended (control) lysimeters. Grasses in the fly ash and topsoil/compost amended lysimeters, leached with only distilled water, exhibited $100 \%$ survival and showed good growth characteristics over the nine-month period. Not only was the grass capable of growing in the cover material, but root growth into the reject material was clearly exhibited by the end of the study. The ash (A-Area power plant) amendment significantly $(\mathrm{p}<0.05)$ enhanced plant growth over all other treatments (Figure 8). The use of VAM inoculant showed some outward benefits to plant growth with respect to color, however, the inoculum did not significantly enhance plant biomass. The use of inoculum for the tree species, on the other hand, was essential for tree survival in the basin material. During the three-month period, non-inoculated pines exhibited an $83 \%$ mortality rate compared to a $3 \%$ mortality of Pt inoculated seedlings. Based upon these results, a combination of surface amendments and mycorrhizal fungus were identified for the field deployment at the 488D basin. 
The use of $\mathrm{H}_{2} \mathrm{O}_{2} / \mathrm{KH}_{2} \mathrm{PO}_{4} / \mathrm{NaOAc}$ as a pyrite microencapsulator showed some benefit from the standpoint of eluent water quality (Table 2), but was deleterious to plant growth and survival. Nearly all of the grass sprigs died in these pots. Even though the overall pyrite oxidation rate was lowered in the $\mathrm{H}_{2} \mathrm{O}_{2} / \mathrm{KH}_{2} \mathrm{PO} / \mathrm{NaOAc}$ pots, extracts from soil samples collected in the upper $10 \mathrm{~cm}$ showed elevated sulfate and EC concentrations over that of the non treated pots. The $\mathrm{H}_{2} \mathrm{O}_{2}$ may have contributed to heightened oxidation of pyrite at the surface, and oxidation of the naturally occurring passivating agents of OM within the amended layer. As such, maintenance of a lower oxidation potential within the surface layer of pots leached only with distilled water may have resulted in lower plant mortality.

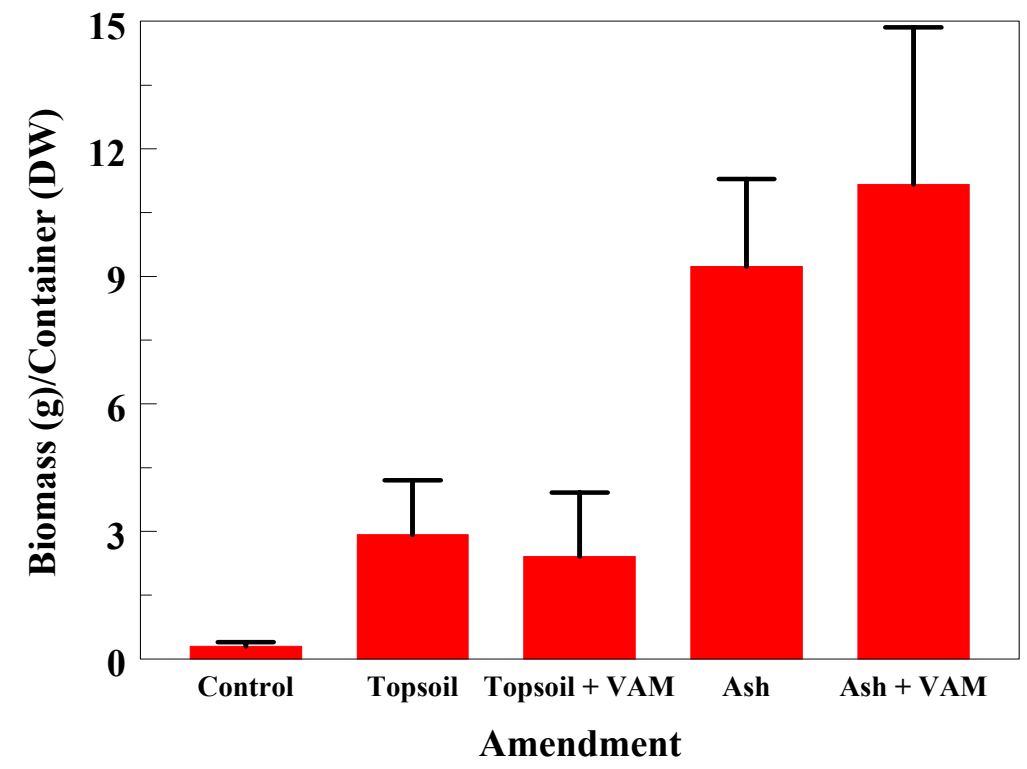

Figure 8. Biomass of bahiagrass per container from greenhouse study ( $\mathrm{n}=4$ pots).

Table 2. Eluent chemistry from microencapsulation study.

\begin{tabular}{|c|c|c|}
\hline Parameter & Conc. with coating & Conc. without coating \\
\hline pH (su) & $2.49(0.12)$ & $2.32(0.2)$ \\
\hline $\mathrm{EC}(\mathrm{mS})$ & $4150(249)$ & 4850 (197) \\
\hline $\mathrm{Fe}\left(\mathrm{mg} \mathrm{L}^{-1}\right)$ & $395(47)$ & $555(62)$ \\
\hline $\mathrm{SO}_{4}\left(\mathrm{mg} \mathrm{L}^{-1}\right)$ & $1580(101)$ & $2140(163)$ \\
\hline $\mathrm{Al}\left(\mathrm{mg} \mathrm{L}^{-1}\right)$ & $131(29)$ & $124(21)$ \\
\hline Acidity $\left(\mathrm{CaCO}_{3}\right.$ eq. $)$ & $1085(97)$ & $1230(144)$ \\
\hline
\end{tabular}




\section{Field Study}

\section{Soils and Sediment Characterization}

Chemical characteristics of the cover materials and the untreated basin material are presented in Table 3. The $\mathrm{pH}$ of the soil, biosolid and ash materials were neutral to slightly acidic, while the basin material was highly acidic and potentially phytotoxic. The coal reject material and the A-area ash were greatly limited with respect to nutrients. Both showed no measurable nitrate or phosphorous concentrations, and exhibited very low potassium content $\left(<10 \mathrm{mg} \mathrm{L}^{-1}\right)$. Both materials were characterized by an elevated iron and aluminum concentration, which was over that of background levels for Coastal Plain soils in South Carolina (Canova, 1999) but not in the critical range for plant growth and survival. Arsenic concentrations for the ash and reject material, however, were within the critical range for plant toxicity $\left(20-50 \mathrm{mg} \mathrm{kg}^{-1}\right)$ (Alloway, 1990). The ash and reject materials also exhibited a relatively high carbon content, which may be attributed to coal particles within the waste material. The topsoil and biosolid substrates were more enriched with basic plant nutrients $(\mathrm{N}, \mathrm{P}, \mathrm{K})$ and did not contain elements that pose plant toxicity concerns.

Table 3. Chemical characteristics of substrate materials prior to application*.

\begin{tabular}{|c|c|c|c|c|}
\hline Parameter & Soil & Biosolid/compost & Ash & $\begin{array}{c}\text { Coal Reject } \\
\text { Material }\end{array}$ \\
\hline $\mathrm{pH}(1: 1)$ & $5.07(0.62)$ & $6.83(1.03)$ & $5.25(0.35)$ & $1.72(0.75)$ \\
\hline $\mathrm{EC}(1: 5)$ & $0.07(0.08)$ & $2.66(0.53)$ & $1.2(0.28)$ & $5.92(1.86)$ \\
\hline $\mathrm{NO}_{3}-\mathrm{N}$ & $10.3(3.0)$ & $31.0(14.7)$ & $\mathrm{BDL}$ & $\mathrm{BDL}$ \\
\hline $\mathrm{P}^{\dagger}$ & $6.8(2.9)$ & $\mathrm{BDL}$ & BDL & BDL \\
\hline $\mathrm{K}^{\dagger}$ & $17.2(10.0)$ & $79.6(19.2)$ & $8.5(0.7)$ & $2.3(1.5)$ \\
\hline $\mathrm{Mg}^{\dagger}$ & $48.7(34.3)$ & $146.0(107.6)$ & $7.5(4.9)$ & $174.3(82.2)$ \\
\hline $\mathrm{Ca}^{\dagger}$ & $208.2(118.3)$ & $766.3(64.5)$ & $272(67.8)$ & $526.0(47.0)$ \\
\hline $\mathrm{Al}^{\dagger}$ & $4193.8(146.3)$ & 430 & 3960 & $1767.9(495)$ \\
\hline $\mathrm{Fe}^{\ddagger}$ & $3510.5(195.5)$ & 351 & 8220 & $20476.4(13827.1)$ \\
\hline $\mathrm{Mn}^{\ddagger}$ & $222.3(8.89)$ & 2.33 & 42.5 & $7.18(12.3)$ \\
\hline $\mathrm{Zn}^{+}$ & $14.3(11.1)$ & 4.95 & 11.5 & $1.96(6.00)$ \\
\hline $\mathrm{Cd}^{+}$ & BDL & 0.13 & BDL & $0.1(0.58)$ \\
\hline $\mathrm{Pb}^{\ddagger}$ & $8.15(1.1)$ & & 18.9 & $28.4(12.4)$ \\
\hline $\mathrm{As}^{\dagger}$ & $9.88(0.72)$ & BDL & 33.4 & $64.7(43.0)$ \\
\hline $\mathrm{Se}^{\ddagger}$ & $\mathrm{BDL}$ & BDL & 7.77 & $8.88(5.80)$ \\
\hline OM $(\%)$ & & 31.9 & & \\
\hline $\mathrm{C}(\%)$ & $1.29(1.22)$ & $13.3(1.0)$ & $26.4(1.2)$ & $11.6(2.25)$ \\
\hline $\mathrm{N}(\%)$ & $0.08(0.05)$ & $0.41(0.6)$ & $0.48(0.8)$ & $0.21(0.04)$ \\
\hline
\end{tabular}

${ }^{*} \mathrm{mg} / \mathrm{Kg}$ except where noted otherwise.

${ }^{\dagger}$ Mehlich-1 method $\left(\mathrm{HNO}_{3}-\mathrm{H}_{2} \mathrm{SO}_{4}\right)$.

U.S. EPA method $200.2\left(\mathrm{HNO}_{3}-\mathrm{HCl}\right)$.

$\mathrm{BDL}=$ below detection 
Soil $\mathrm{pH}$ levels from samples collected after the treatments were established exhibited wide variation ( $\mathrm{pH}$ range $1.19-7.65)$ in the $0-10 \mathrm{~cm}$ depths (Table 4$)$. The average $\mathrm{pH}$ for the three blocks was similar to levels measured prior to their application (Table 3 ). The Block A control treatment showed a slightly higher $\mathrm{pH}$ than that of Blocks B and C $(2.63$ vs. $<1.5)$ and was attributed to the incorporation of Carolina compost in the subsurface. The compost/mulch cover exhibited a $\mathrm{pH}$ that was nearly $2 \mathrm{pH}$ units higher (average 6.82) than the topsoil or flyash. At the $40-50 \mathrm{~cm}$ depth, below the cover layer, $\mathrm{pH}$ values converged ( $\mathrm{pH}$ range $1.58-3.84$ ) and little influence from the amendments was observed. Again, the influence of the compost incorporation in Block A was observed in the control, compost and apatite treatments, but was surprisingly absent in the topsoil and flyash plots.

Table 4. Average $\mathrm{pH}(1: 1)$ of $488-\mathrm{D}$ sediments at $0-10$ and $40-50 \mathrm{~cm}$ depths $(\mathrm{n}=3) \dagger$.

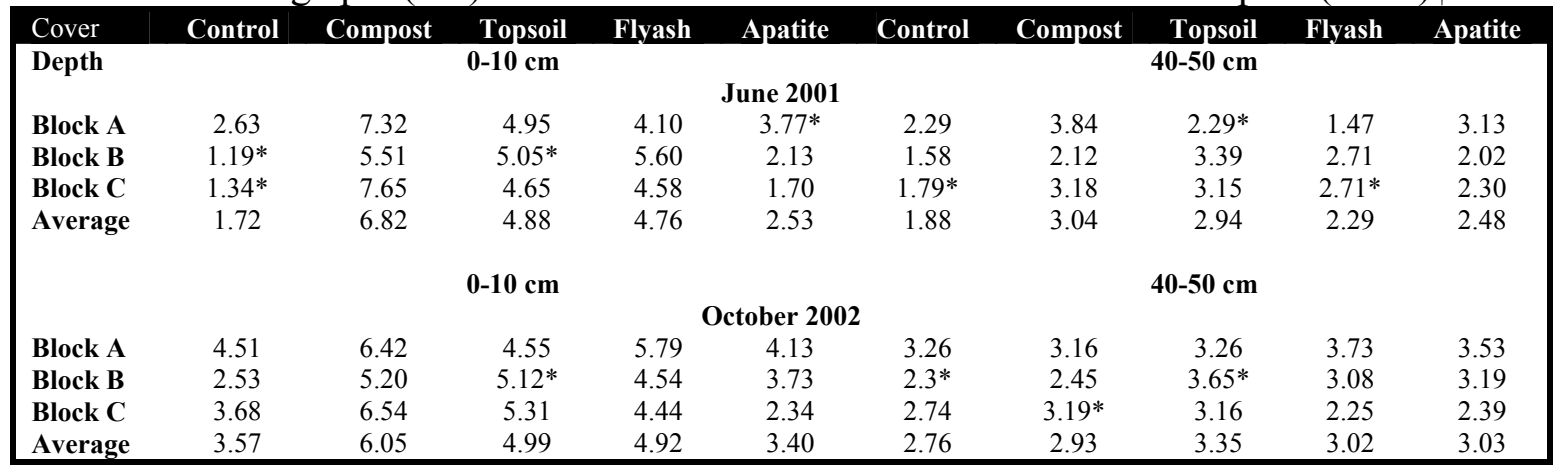

$\dagger$ Standard deviation of the mean $<20 \%$ for all samples except those identified with an *.

After two growing seasons soil $\mathrm{pH}$ exhibited a general increase over that observed during the first sample event. Changes in soil chemistry as influenced by litter layer development and plant establishment may have contributed to this increase. However, $\mathrm{pH}$ increases were noted in plots that exhibited complete mortality. This suggests that a geochemical, rather than biological, process may be responsible for the $\mathrm{pH}$ difference between years. It is likely that the time of sampling and moisture conditions on the basin influenced the results. The first sample event occurred during a prolonged hot and dry period, which was conducive for the formation of evaporative salts on the basins' surface. Efflorescent salts, that were later identified as coquimbite $\left(\mathrm{Fe}_{2}{ }^{\mathrm{III}}\left(\mathrm{SO}_{4}\right)_{3} \cdot 9 \mathrm{H}_{2} \mathrm{O}\right)$ and gypsum $\left(\mathrm{CaSO}_{4} \bullet 2 \mathrm{H}_{2} \mathrm{O}\right)$, were observed during this period. These salts can be highly acidic $(\mathrm{pH} \approx 1.0)$ and are often thought to be the primary source of acidity on waste sites containing appreciable amounts of pyrite (Barton et al, 2003). Samples from October 2002 were collected following a series of rain events and no efflorescent salts were visible on the surface. As such, the highly reactive (and acidic) salts were not present in these samples. In general, however, the range in $\mathrm{pH}$ and distribution between plots and subsurface blocks was similar in 2002 as it was in 2001 (Table 4). 
Electrical conductivity (EC) can be utilized as an indirect measure of ionic strength and salinity in soils (Evangelou, 1999). Sediment EC concentrations from the control plots exhibited a general inverse correlation to that of $\mathrm{pH}$ (Table 5). This relationship supports the hypothesis that salts were present on the surface in 2001, but absent in 2002.

Sediments from the topsoil and ash plots at both depths, on the other hand, exhibited large increases in EC from 2001 to 2002 but did not show an associated change in $\mathrm{pH}$. It is possible that these two cover treatments were enriched with ionic constituents due to evaporation as described earlier. Alternatively, the two treatments were the most successful with respect to plant establishment and the enrichment may be due to enhanced migration of ionic components into the rhizosphere via ectomycorrhizal fungi, or by the presence of plant roots exudates (Koo et al., 2003).

Table 5. Average EC (1:3) of 488-D sediments at 0-10 and 40-50 $\mathrm{cm}$ depths $(\mathrm{n}=3) \dagger$.

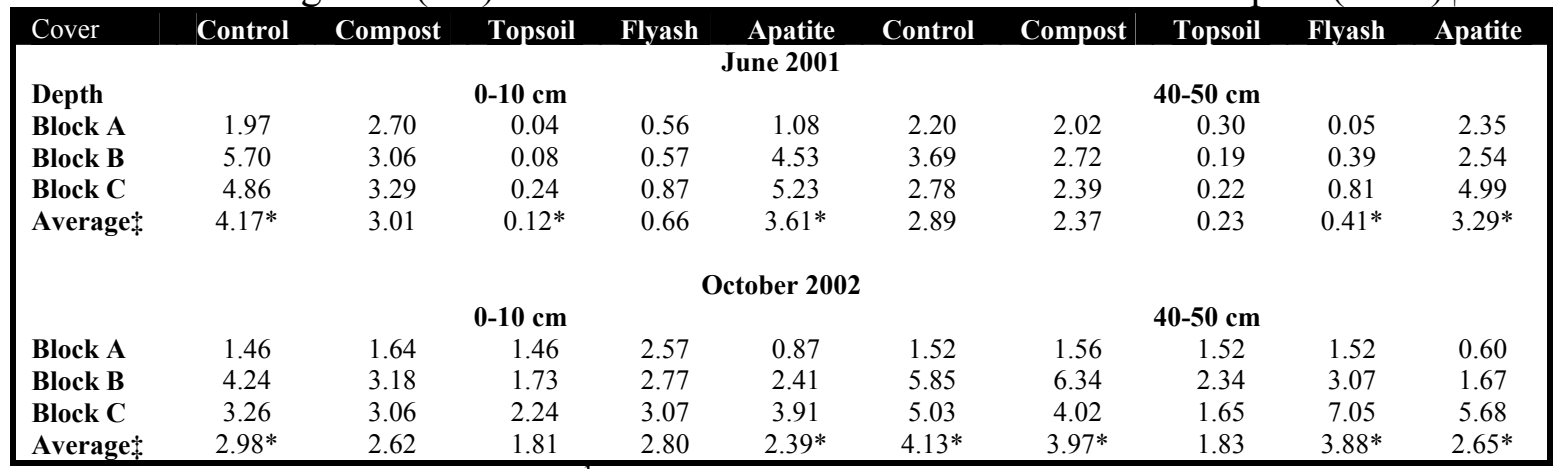

†units of measurement $=\mathrm{mS} \mathrm{cm} \mathrm{cm}^{-1}$.

tstandard deviation of the mean between blocks $>50 \%$ for those indicated with an *.

Average total elemental composition for samples collected July 2001 at the 0-10 and 40$50 \mathrm{~cm}$ depths are presented in Table 6 . Results represent an average of one sample from each block for every surface treatment $(n=3)$. In general, the surface sediments contained lower elemental concentrations than the lower depths. The $0-10 \mathrm{~cm}$ compost/mulch treatment was characterized by a much higher calcium concentration than the other treatments. This was likely the result of lime addition to the material during the composting process, which is reflective by a high $\mathrm{pH}$ (Table 4). As indicated earlier, iron concentrations were much higher than background levels for South Carolina soils, particularly at the lower depth. In addition, arsenic concentrations were within or above the critical toxic range for all samples. Total $\mathrm{C}(13$ to $24 \%)$ and $\mathrm{N}(0.25$ to $0.55 \%)$ content was similar for all treatments and blocks regardless of depth (Table 7). 
Table 6. Average total elemental composition of 488-D sediments at $0-10$ and $40-50 \mathrm{~cm}$ depths $(\mathrm{n}=3) \dagger$.

\begin{tabular}{|c|c|c|c|c|c|c|c|c|c|c|}
\hline Cover & Control & Compost & Topsoil & Flyash & Apatite & Control & Compost & Topsoil & Flyash & Apatite \\
\hline Depth & \multicolumn{5}{|c|}{$0-10 \mathrm{~cm}(\mathrm{mg} / \mathrm{kg})$} & \multicolumn{5}{|c|}{$40-50 \mathrm{~cm}(\mathrm{mg} / \mathrm{kg})$} \\
\hline Al & 1005.7 & 8365.1 & 3718.0 & 5951.5 & 3250.5 & 3988.5 & 6743.2 & 4559.8 & 5355.2 & 6600.6 \\
\hline As & 50.4 & 85.0 & 45.2 & 53.23 & 110.2 & 108.2 & 119.9 & 29.6 & 120.6 & 69.6 \\
\hline $\mathbf{C a}$ & 7092.0 & 76913.4 & 250.9 & 5973.2 & 3820.0 & 5513.9 & 6880.8 & 1884.2 & 4565.3 & 4736.8 \\
\hline Cd & BDL & BDL & BDL & BDL & BDL & BDL & BDL & BDL & 0.1 & BDL \\
\hline $\mathrm{Cr}$ & 3.8 & 27.9 & 7.3 & 9.94 & 13.4 & 10.5 & 21.2 & 14.4 & 17.4 & 13.2 \\
\hline $\mathbf{C u}$ & 14.6 & 52.5 & 7.6 & 35.3 & 29.2 & 24.5 & 43.2 & 28.7 & 34.3 & 27.3 \\
\hline $\mathbf{F e}$ & 22936.5 & 7169.1 & 4329.5 & 11954.5 & 58816.6 & 30850.0 & 53979.3 & 27044.3 & 38627.2 & 46628.5 \\
\hline $\mathbf{K}$ & 700.0 & 1079.4 & BDL & 304.1 & 1177.1 & 749.7 & 978.2 & 460.3 & 1005.9 & 1316.7 \\
\hline Mg & 292.2 & 2028.8 & 98.0 & 1550.6 & 400.4 & 423.6 & 575.9 & 371.7 & 844.7 & 245.2 \\
\hline Mn & 23.9 & 198.4 & 62.9 & 48.7 & 87.6 & 64.1 & 206.1 & 124.4 & 134.6 & 100.4 \\
\hline $\mathbf{N a}$ & 226.0 & 1045.2 & 103.1 & 186.7 & 527.5 & 319.0 & 348.9 & 248.1 & 432.6 & 349.4 \\
\hline $\mathbf{N i}$ & 8.8 & 19.2 & 7.3 & 29.7 & 23.1 & 9.6 & 14.9 & 9.2 & 22.2 & 10.4 \\
\hline $\mathbf{P b}$ & BDL & BDL & BDL & BDL & BDL & BDL & BDL & BDL & 4.0 & 6.1 \\
\hline Se & BDL & 20.4 & 20.2 & BDL & 32.8 & 35.9 & 57.9 & 24.3 & 38.3 & 2.4 \\
\hline Zn & 62.6 & 104.6 & 60.6 & 65.7 & 43.8 & 64.4 & 74.9 & 86.0 & 81.3 & 67.4 \\
\hline
\end{tabular}

†USEPA Method $200.2\left(\mathrm{HNO}_{3}-\mathrm{HCl}\right.$ digestion).

Table 7. Carbon and nitrogen content of 488-D sediments at 0-10 and 40-50 cm depths $(\mathrm{n}=3)$.

\begin{tabular}{|c|c|c|c|c|c|c|c|c|c|c|}
\hline Cover & Control & Compost & Topsoil & Flyash & Apatite & Control & Compost & Topsoil & Flyash & Apatite \\
\hline & \multicolumn{10}{|c|}{ Carbon (\%) } \\
\hline Depth & \multicolumn{5}{|c|}{$0-10 \mathrm{~cm}$} & \multicolumn{5}{|c|}{$40-50 \mathrm{~cm}$} \\
\hline Block A & 19.3 & 19.4 & 16.4 & 24.4 & 18.5 & 22.2 & 14.7 & 16.1 & 12.6 & 12.6 \\
\hline Block B & 17.8 & 18.4 & 13.5 & 19.1 & 21.4 & 17.4 & 17.9 & 18.5 & 15.8 & 17.4 \\
\hline \multirow[t]{3}{*}{ Block C } & 19.2 & 19.5 & 15.5 & 21.2 & 22.3 & 19.4 & 22.2 & 19.8 & 19.3 & 21.3 \\
\hline & \multicolumn{10}{|c|}{ Nitrogen (\%) } \\
\hline & & & $0-10 \mathrm{~cm}$ & & & & & $40-50 \mathrm{~cm}$ & & \\
\hline Block A & 0.49 & 0.45 & 0.37 & 0.42 & 0.43 & 0.48 & 0.30 & 0.34 & 0.25 & 0.26 \\
\hline Block B & 0.41 & 0.48 & 0.31 & 0.40 & 0.45 & 0.36 & 0.37 & 0.40 & 0.32 & 0.36 \\
\hline Block C & 0.37 & 0.55 & 0.31 & 0.47 & 0.52 & 0.39 & 0.46 & 0.40 & 0.40 & 0.45 \\
\hline
\end{tabular}

Average soil temperature was higher in the experimental plots and in the control over that observed in a naturally vegetated area on the basin (Figure 9). Given the dark color of the basin material and relative lack of shade, a potential temperature effect on seedling survival was anticipated. During the first year there were no significant differences in surface temperature between the plots. Some shade was provided during the summer of 2002 as the vegetation grew and litter began to accumulate on the plots. However, the degree of protection over that of the control was limited and still significantly higher than that observed in the vegetated area. As the trees grow and canopy cover is achieved, we anticipate that the temperature on the plots will begin to move toward that of the vegetated area. However, the high temperatures exhibited (particularly the daily maximum) serve as another stress in this environment and will likely contribute to enhanced mortality, especially in dry years. 


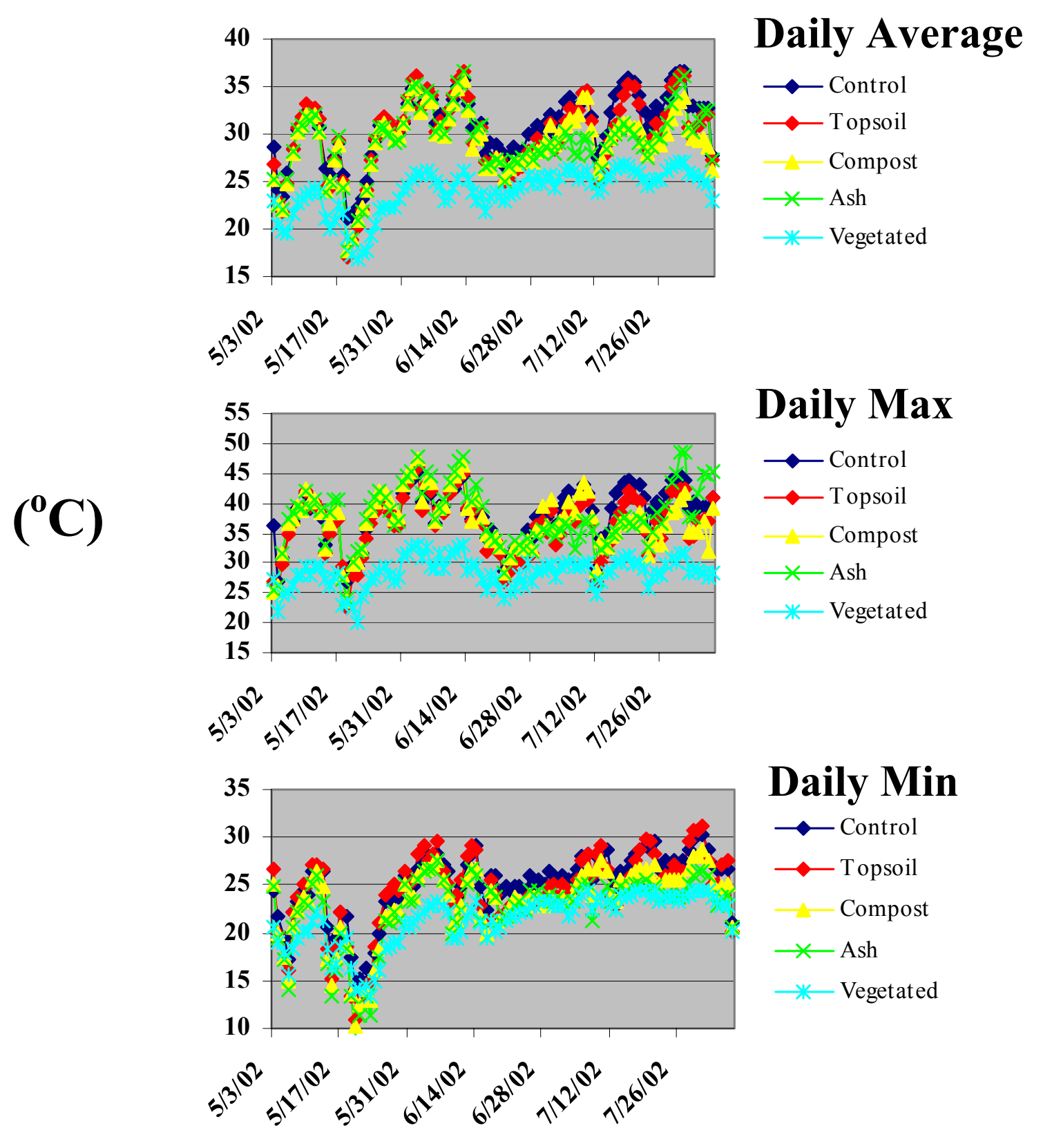

Figure 9. Soil temperature at $10-\mathrm{cm}$ below surface on plots at the 488-D basin.

\section{Vegetation Characterization}

For the discussion of vegetation survival, data obtained during comprehensive surveys performed in October 2001 and 2002 were utilized. At these points in time, the seedlings had been in the field for one and two growing seasons, respectively. Examination of the blocking effect on seedling survival after one year revealed that block A exhibited the highest survival (70\%) followed by blocks B (52\%) and C (37\%) (Figure 10). After two growing seasons Block A still exhibited the highest survival (62\%) followed by blocks B $(33 \%)$ and $C(21 \%)$. For 2002, survival in Block A was significantly greater than that in 
both Blocks B and C. This response is likely the result of enhanced physicochemical characteristics of the plots due to ripping and compost incorporation. Not only does Block A exhibit a higher surface $\mathrm{pH}$ (especially in the control and apatite covers), but it also exhibited lower compaction which aids the system by allowing for root penetration, gas exchange and water infiltration (Table 8) (Bledsoe et al., 1992). A high standard deviation of the mean suggested that wide variation amongst the surface treatment existed. Growth curves of the loblolly seedlings within each block revealed a similar relationship, where plants from Block A exhibited elevated heights over that of the other Blocks (Figure 11). The height of the loblolly seedlings in Block A was also elevated over those in a non-contaminated site with native soil, particularly in the plots that received a surface amendment. Whole tree harvesting from the site, after one growing season, also indicated an elevated biomass and root volume in Block A over Blocks B, C and the native soil (Table 9). The inoculation index of plants growing on all plots was high. Ectomycorhizal $P t$ fruiting bodies were observed outside of the plot boundaries during the 2002 growing season, which indicated that the root was capable of growing out of the cover material and into the 488-D medium.

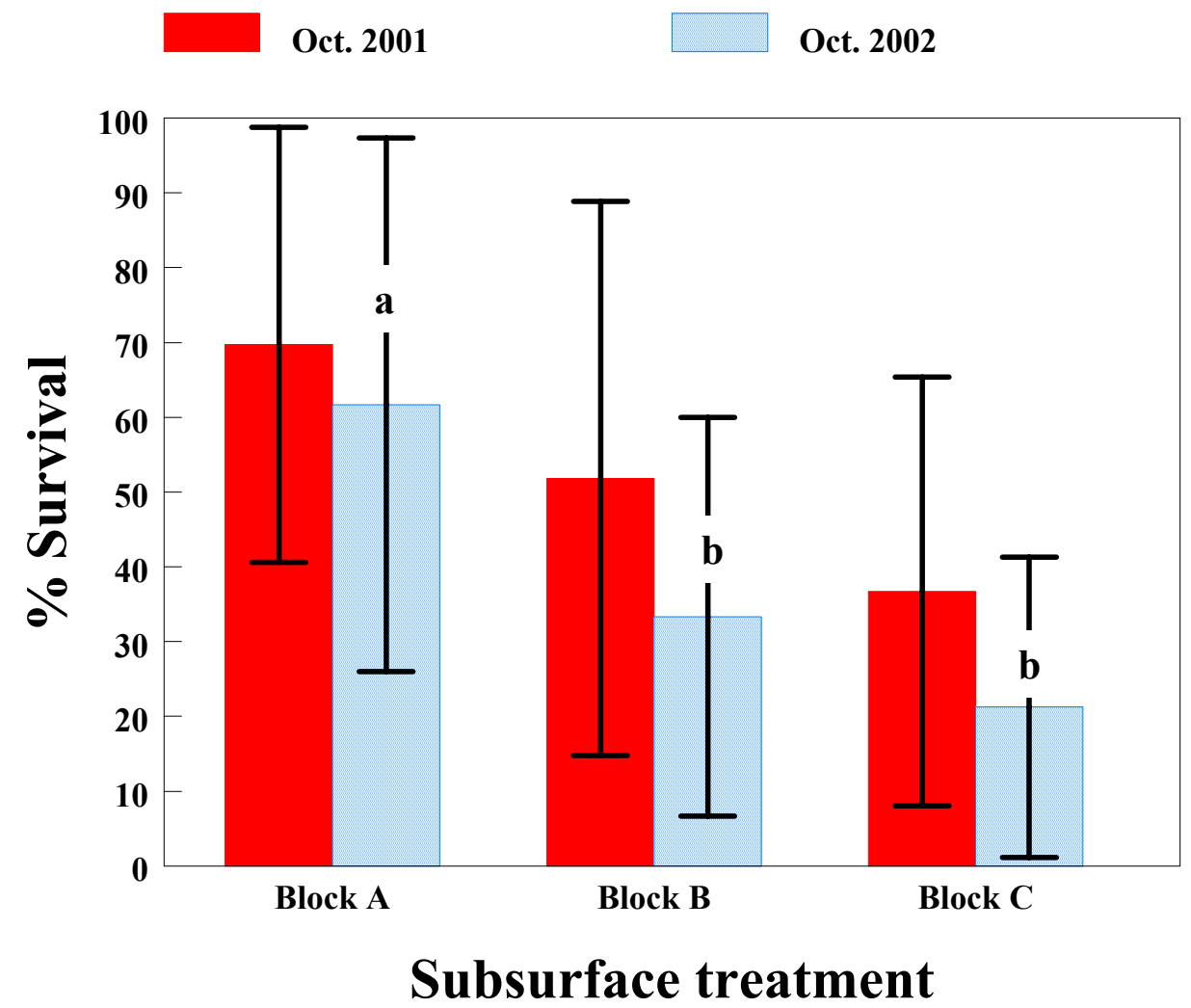

Figure 10. Vegetation survival by block on the 488-D basin. 
Table 8. Penetrometer resistance (psi) at the 488-D basin.

\begin{tabular}{|l|ccc|c|}
\hline Depth $(\mathrm{cm})$ & \multicolumn{2}{c|}{ Block A } & Block B & Block C \\
\hline $\mathbf{0 - 1 0}$ & 39 & December 2001 & \\
$\mathbf{1 0 - 2 0}$ & 116 & 106 & 176 \\
$\mathbf{2 0 - 3 0}$ & 116 & 141 & 243 \\
$\mathbf{3 0 - 4 0}$ & 174 & 193 & $>300$ \\
& & November 2002 & $>300$ \\
$\mathbf{0 - 1 0}$ & 92 & & \\
$\mathbf{1 0 - 2 0}$ & 150 & 195 & 273 \\
$\mathbf{2 0 - 3 0}$ & 190 & 210 & $>300$ \\
$\mathbf{3 0 - 4 0}$ & 217 & 280 & $>300$ \\
\hline
\end{tabular}

Table 9. Mean growth characteristics from seedlings harvested after one year $(n=4)$.

\begin{tabular}{|lccccc|}
\hline Site & Biomass $(\mathrm{g})$ & Root Volume $\left(\mathrm{ft}^{3}\right)$ & \multicolumn{3}{c|}{ Inoculation Index $(\%) \dagger$} \\
Block A & 85.9 & 2.69 & $\frac{\boldsymbol{P t}}{63}$ & $\frac{\boldsymbol{S c}}{7}$ & $\frac{\boldsymbol{T t}}{7}$ \\
Block B & 38.0 & 0.50 & 63 & 12 & 3 \\
Block C & 33.1 & 0.67 & 41 & 4 & 0 \\
Native Soil* & 18.7 & 1.27 & 3 & 8 & 0 \\
\hline
\end{tabular}

$\dagger P t=$ Pisolithus tinctorius; $S c=$ Scleroderma cepa; $T t=$ Thelephora terrestris

* Planted in an uncontaminated area $(\mathrm{n}=2)$.

Seedling surveys by surface treatment groups indicated that the ash and topsoil amendments greatly improved survivability on the basin (Figure 12). Mortality of less than $25 \%$ was exhibited in those treatments on Block A. The apatite treatment was impressive in one plot on Block A that exhibited 97\% survival; however, survival in blocks B and $\mathrm{C}$ did not differ significantly from that observed in the control. The Block A topsoil treatment exhibited a significantly higher survival than those with the same cover in Blocks B and C. The ash treatment in Blocks A and B was significantly higher than that observed in Block $\mathrm{C}$. The mulch treatment exhibited the most consistent survival characteristics across the blocking units, varying less than $20 \%$ between blocks. The only significant difference in survival with respect to the interaction across surface treatments was observed between Block A-topsoil and Block A-mulch. Although statistical analyses were not possible for the apatite and control treatments due to complete mortality in some plots, the importance of the amendments on plant survival and growth is clearly evident (Figure 13). 


\section{\begin{tabular}{l|l|l|} 
April 01 & October 01 & October 02
\end{tabular}}

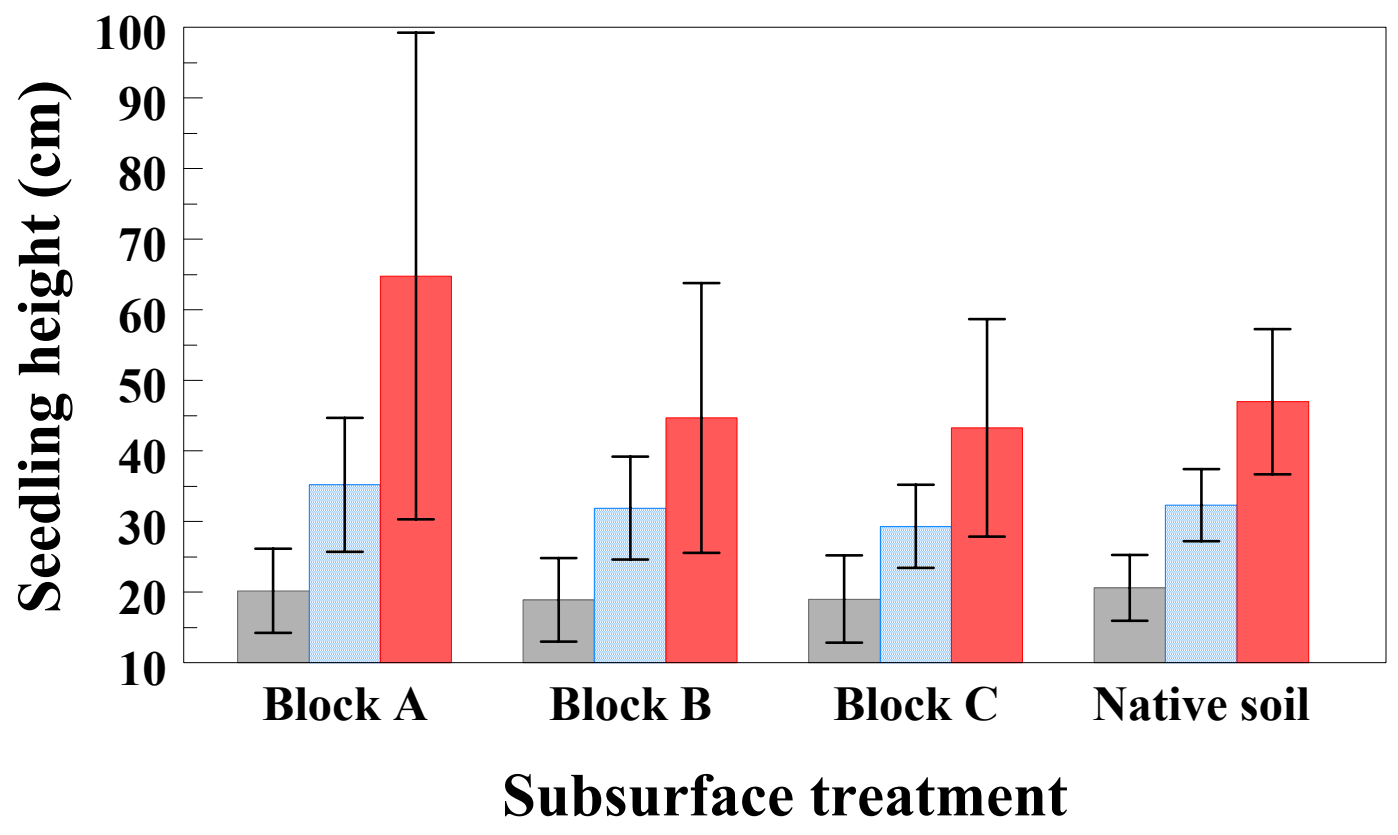

Figure 11. Loblolly seedling growth by block for two growing seasons on the 488-D basin. Native soil was located on an uncontaminated plantation (SRWC) site at the Savannah River Site. Seedlings planted at the Native site were obtained from the same planting source as those on the basin. 

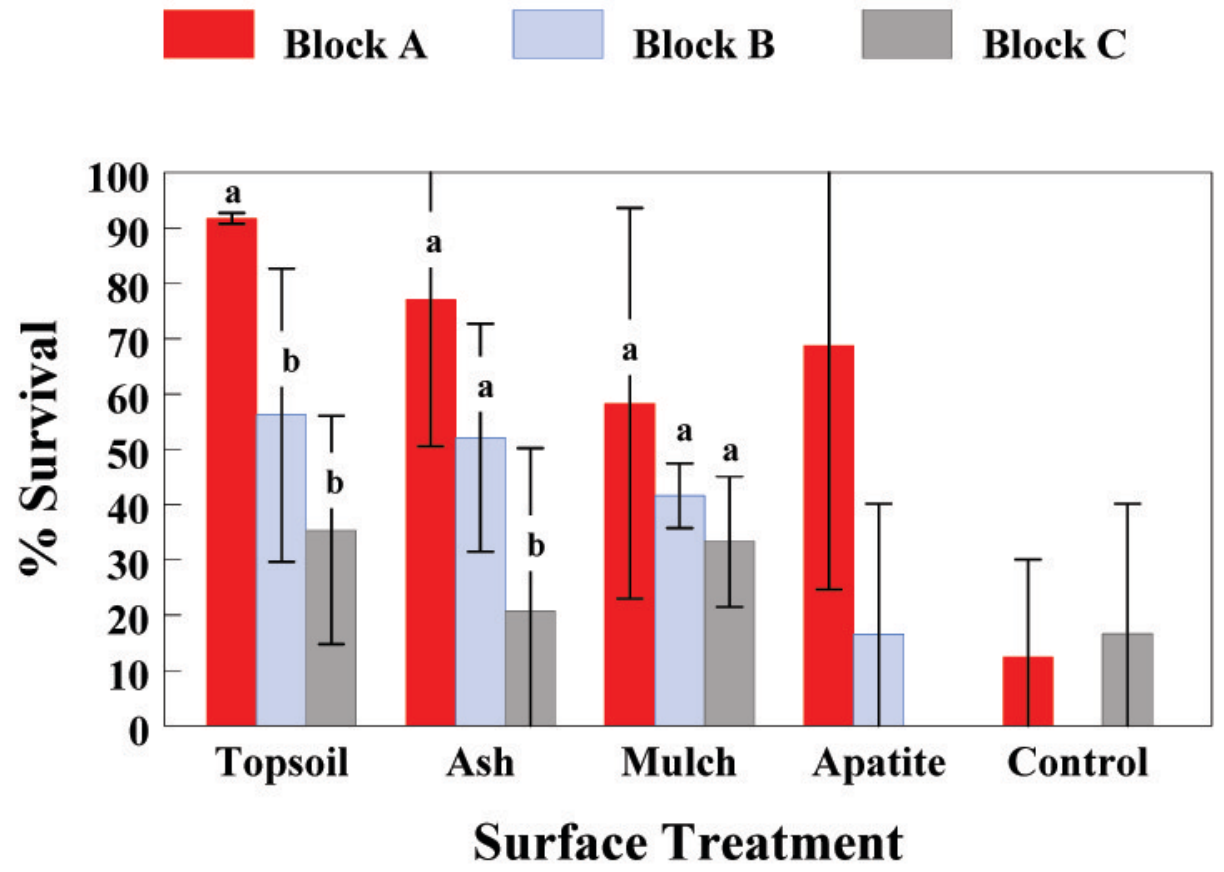

Figure 12. Vegetation survival by surface treatment and block on the 488-D basin.

\section{8-D Vegetation Cover August 2002}

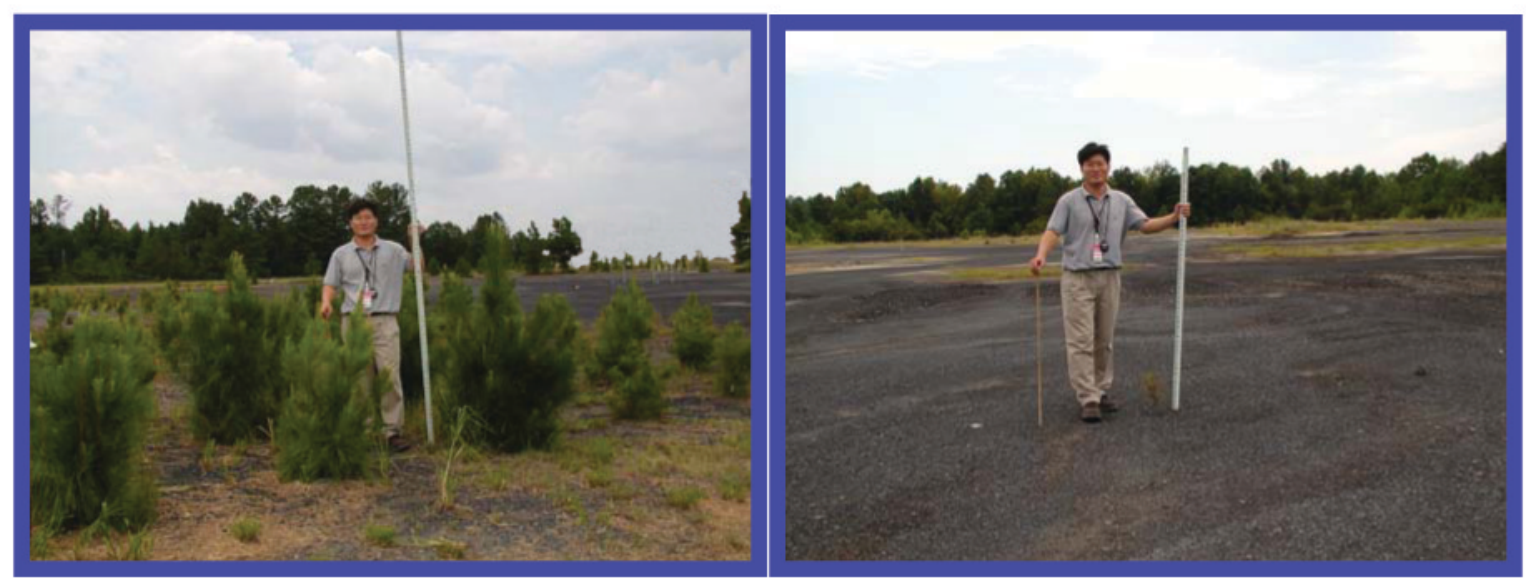

Block A/Apatite

Block B /Control

Figure 13. Pictures of seedlings in Block A - Apatite and Block B - Control treatments during second growing season. 
Comparison of the treatment groups to surface $\mathrm{pH}$ revealed that the ash and topsoil plots were being maintained at levels consistent with those of the native soils on the Savannah River Site $(1: 1 \mathrm{pH} \approx 5.0)$. The apatite and control groups exhibited $\mathrm{pH}$ values in the 2 to 3 range, which was deleterious to plant growth and survival. The apatite plots responded positively in Block A, which coincidently exhibited a surface $\mathrm{pH}$ near 4.0 for both years sampled. The mulching treatment, on the other hand, maintained a $\mathrm{pH}$ above 6.0 for most plots. Although this $\mathrm{pH}$ level appears ideal given the preexisting conditions of the basin, some pines show developmental problems under alkaline soil conditions. By examining the different pine species and stock under the varying treatments, the influence of the higher $\mathrm{pH}$ on survival of Virginia pine is revealed (Figure 14). Loblolly pine in the mulch treatment showed moderate survival rates $(\approx 50 \%)$, while the Virginia pine exhibited high mortality (95\%). The Virginia pines actually outperformed the loblolly in the topsoil, apatite and control groups; thus, mortality of the Virginia pine is likely attributed to a chemical characteristic within the mulch that was not present in the other amendments. This may be directly related to the alkaline conditions of the material, or due to a synergistic effect from heightened bioavailability of a potentially harmful chemical under the higher $\mathrm{pH}$ conditions. Examination of the plant tissue analyses indicated that the nutrient sufficiency levels listed for loblolly pine (Campbell, 2001) (ie. N- 1.1\%, P-0.1\%, $\mathrm{K}-0.35 \%, \mathrm{Ca}-0.12 \%$ and $\mathrm{Mg}-0.07 \%$ ) were exceeded in all plots (Table 10). Phosphorous levels were below detection levels in the basin material and all of the cover amendments with the exception of the topsoil (Table 3 ). The presence of adequate P levels in plant tissue is possibly attributed to the potting soil and residual fertilizers from the containers where the seedlings were germinated. Careful observation of the seedling color and additional tissue analysis will need to be performed to ensure that $\mathrm{P}$ deficiency problems do not arise in the future.

Total elemental composition of the loblolly seedlings did reveal significantly higher tissue concentrations of selenium and boron in the ash and compost plots over that of the other surface treatments (Table 11). Phytotoxicity of boron in Pinus is species specific but has been documented at levels ranging from 75 to $500 \mathrm{mg} \mathrm{kg}^{-1}$ (Adriano, 2001). Yellowing of needles, which is a sign of boron toxicity, was noted on ash plots throughout the study. Although tissue analysis was not performed on the VA pine, the potential for boron toxicity in these plots is evident and an increased mortality due to heightened sensitivity over that of the loblolly is possible. Arsenic concentrations were not "significantly" different between treatments, but levels on the basin seedlings were much greater than those observed at the native soil site. Because the native soil As levels were below detection, computation of a statistical difference between the plots on the basin was not possible. 


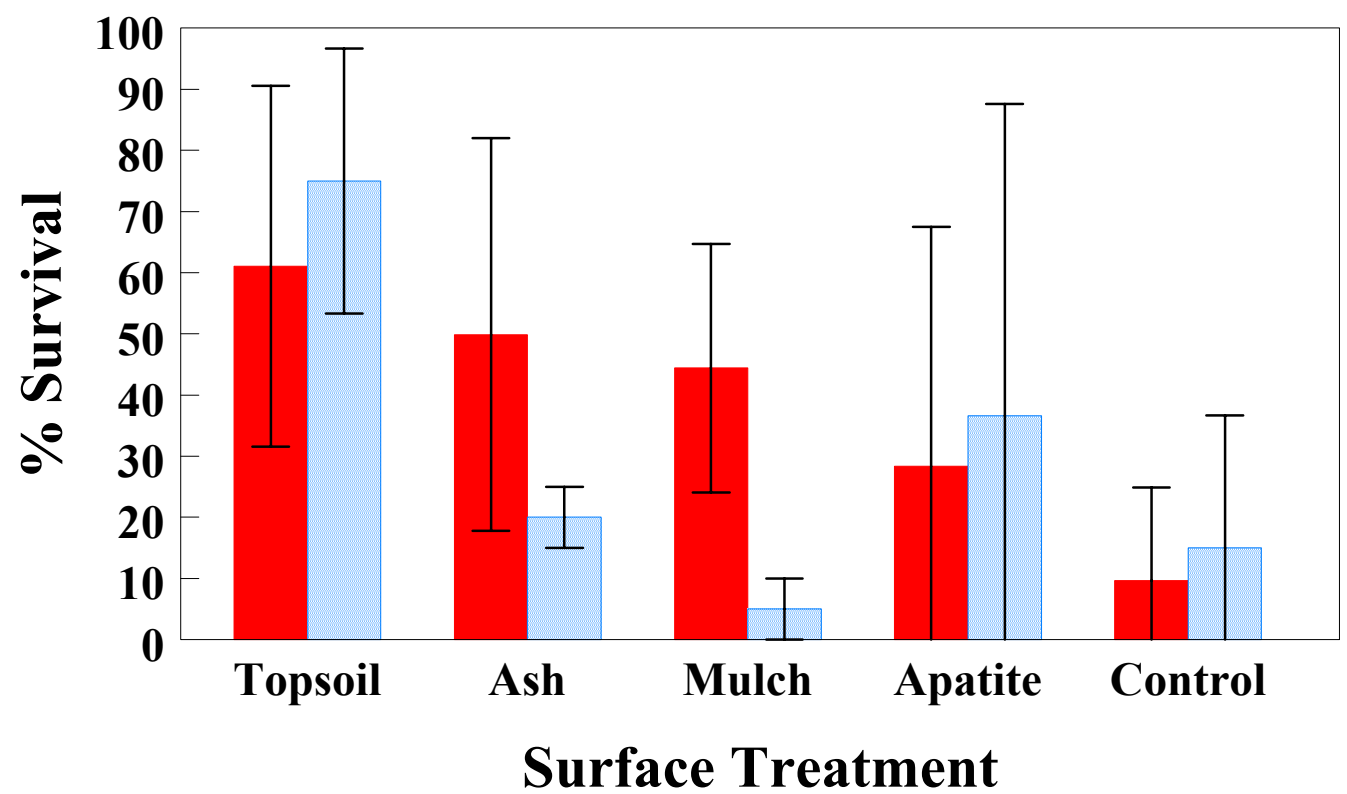

Figure 14. Effect of surface treatment on survival of differing species on the 488-D basin.

Table 10. Plant tissue nutrient composition after two growing seasons $(\mathrm{n}=2) \dagger$.

\begin{tabular}{|c|c|c|c|c|c|c|c|c|c|c|}
\hline Cover & Control & Compost & Topsoil & Flyash & Apatite & Control & Compost & Topsoil & Flyash & Apatite \\
\hline Parameter & & & N (\%) & & & & & P(\%) & & \\
\hline Block A & 1.66 & 1.83 & 1.64 & 1.55 & 1.74 & 0.13 & 0.15 & 0.15 & 0.14 & 0.14 \\
\hline Block B & $\mathrm{n} / \mathrm{a}^{*}$ & 1.45 & 1.67 & 1.34 & 1.83 & $\mathrm{n} / \mathrm{a}$ & 0.12 & 0.15 & 0.15 & 0.13 \\
\hline Block C & 1.71 & 1.60 & 1.62 & 1.70 & $\mathrm{n} / \mathrm{a}$ & 0.12 & 0.12 & 0.14 & 0.17 & $\mathrm{n} / \mathrm{a}$ \\
\hline Parameter & & & K (\%) & & & & & Ca (\%) & & \\
\hline Block A & 0.49 & 6.42 & 0.93 & 0.73 & 0.50 & 0.20 & 0.29 & 0.29 & 0.30 & 0.21 \\
\hline Block B & $\mathrm{n} / \mathrm{a}$ & 5.20 & 0.82 & 0.83 & 0.49 & $\mathrm{n} / \mathrm{a}$ & 0.33 & 0.20 & 0.32 & 0.17 \\
\hline Block C & 0.71 & 6.54 & 0.75 & 0.72 & $\mathrm{n} / \mathrm{a}$ & 0.31 & 0.32 & 0.30 & 0.26 & $\mathrm{n} / \mathrm{a}$ \\
\hline Parameter & & & Mg (\%) & & & & & $\left(\mathrm{mg} \mathrm{kg}^{-1}\right)$ & & \\
\hline Block A & 0.26 & 0.14 & 0.19 & 0.19 & 0.23 & 79 & 305 & 89 & 303 & 114 \\
\hline Block B & $\mathrm{n} / \mathrm{a}$ & 0.25 & 0.17 & 0.24 & 0.26 & $\mathrm{n} / \mathrm{a}$ & 306 & 77 & 383 & 71 \\
\hline Block C & 0.17 & 0.26 & 0.23 & 0.27 & $\mathrm{n} / \mathrm{a}$ & 83 & 386 & 88 & 215 & $\mathrm{n} / \mathrm{a}$ \\
\hline
\end{tabular}

$\dagger$ Wet ash $\mathrm{HNO}_{3}+\mathrm{H}_{2} \mathrm{O}_{2}$ digestion (Ellis et al., 1992).

*Unable to collect sample due to high plant mortality.

Survival of the grass sprigs between blocks was almost identical to that displayed by the seedlings during the first growing season (Figure 15). The vetch and clover species, however, did not survive past the first month. It is likely that those species were not suited for the high temperature, salinity and acidity of the basin's surface. The effect of 
the surface treatments on grass survival were also very similar to that described for the seedlings. The one notable exception was the topsoil treatment where $100 \%$ survival was exhibited for all plots and blocks. In addition, vigorous growth of non-planted grass and weed species was observed on the topsoil plots (Table 12). Because the grasses and weeds may compete with the trees for water and nutrients, and even out compete them in some instances (Vogel, 1980), a decision was made to control the growth of these species during the second growing season. As such, the grass plots and weeds were mowed and additional monitoring of the growth and survival was not performed.

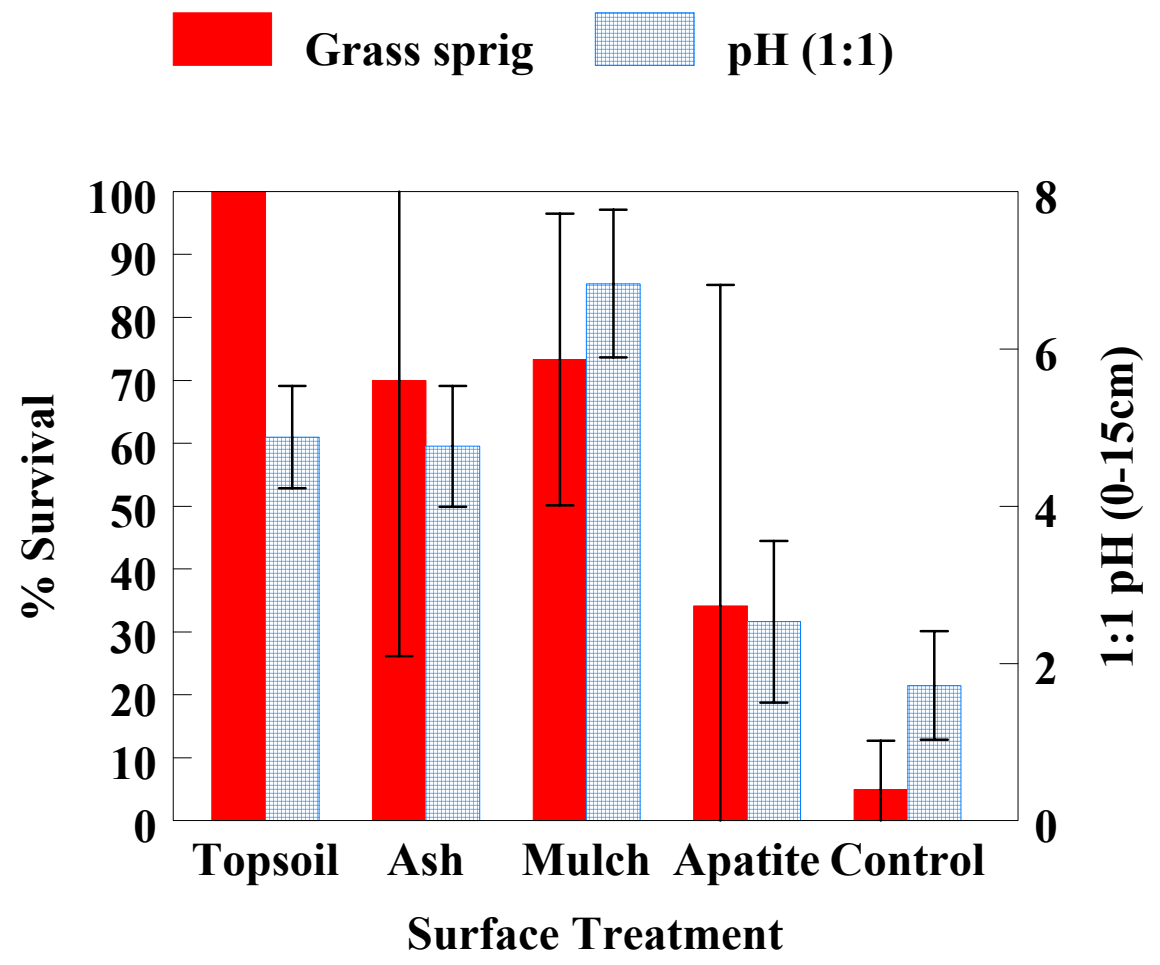

Figure 15. Average survival of planted grass sprigs and associated sediment $\mathrm{pH}$ on the 488-D Ash Basin per surface treatment (2001 growing season). 
Table 11. Average total elemental composition $\left(\mathrm{mg} \mathrm{kg}^{-1}\right)$ of loblolly pine seedlings after one year growth $(\mathrm{n}=2) \dagger$.

\begin{tabular}{|c|c|c|c|c|c|c|c|c|c|c|c|c|c|}
\hline \multicolumn{2}{|c|}{ Cover } & \multicolumn{2}{|c|}{ Control } & \multicolumn{2}{|c|}{ Compost } & \multicolumn{2}{|c|}{ Topsoil } & \multicolumn{2}{|c|}{ Flyash } & \multicolumn{2}{|c|}{ Apatite* } & \multicolumn{2}{|c|}{ Native** } \\
\hline & & $\underline{\mathrm{AVG}}$ & STDEV & $\underline{\mathrm{AVG}}$ & STDEV & $\underline{\mathrm{AVG}}$ & STDEV & $\underline{\mathrm{AVG}}$ & STDEV & $\underline{\mathrm{AVG}}$ & STDEV & AVG & STDEV \\
\hline Al & $\mathbf{s}$ & $\overline{1110}$ & 124 & 792 & 29 & 631 & 250 & 505 & 66 & 788 & & 1224 & 56 \\
\hline$t$ & & 1298 & 337 & 1587 & 19 & 1942 & 2097 & 1147 & 122 & 2238 & & 2692 & 319 \\
\hline As & $\mathbf{s}$ & 7.28 & 1.10 & 4.42 & 2.15 & 0.95 & 0.82 & 7.48 & 0.92 & 8.73 & & $\mathrm{BDL}$ & BDL \\
\hline & $\mathbf{t}$ & 7.95 & 2.04 & 8.57 & 3.11 & 2.45 & 1.09 & 9.95 & 0.61 & 21.3 & & BDL & BDL \\
\hline $\mathrm{Cr}$ & $\mathbf{s}$ & 7.21 & 1.09 & 5.44 & 1.24 & 8.30 & 5.34 & 5.62 & 0.92 & 3.96 & & 6.93 & 0.8 \\
\hline & $\mathbf{t}$ & 17.5 & 6.98 & 10.2 & 1.31 & 15.0 & 6.03 & 14.2 & 5.63 & 12.8 & & 13.6 & 1.54 \\
\hline $\mathrm{Cu}$ & $\mathbf{s}$ & 9.86 & 2.91 & 13.0 & 1.01 & 8.51 & 2.67 & 12.5 & 1.51 & 13.8 & & 6.2 & 0.36 \\
\hline & $\mathbf{t}$ & 24.7 & 10.3 & 30.6 & 3.39 & 17.8 & 6.05 & 38.0 & 24.2 & 37.7 & & 15.3 & 0.21 \\
\hline $\mathrm{Fe}$ & $\mathbf{s}$ & 2704 & 668 & 603 & 117 & 416 & 185 & 501 & 51 & 517 & & 350 & 62 \\
\hline & $\mathbf{t}$ & 3961 & 1263 & 1785 & 9 & 1468 & 124 & 985 & 108 & 4585 & & 1002 & 184 \\
\hline Mn & $\mathbf{s}$ & 419 & 111 & 101 & 31 & 485 & 76 & 54.7 & 12.8 & 144 & & 915 & 51 \\
\hline & $\mathbf{t}$ & 602 & 133 & 147 & 44 & 621 & 138 & 84.0 & 15.7 & 178 & & 1237 & 121 \\
\hline Мо & $\mathbf{s}$ & 0.84 & 0.45 & 3.86 & 2.63 & 0.95 & 0.66 & 4.93 & 1.45 & 0.72 & & 0.72 & 0.41 \\
\hline & $\mathbf{t}$ & 1.41 & 0.27 & 26.8 & 13.4 & 1.81 & 0.98 & 49.0 & 34.0 & 4.16 & & 1.26 & 0.48 \\
\hline $\mathbf{N i}$ & $\mathbf{s}$ & 9.39 & 0.73 & 4.98 & 0.32 & 6.48 & 1.81 & 13.4 & 6.59 & 11.6 & & 7.74 & 3.78 \\
\hline & $\mathbf{t}$ & 20.7 & 1.87 & 11.4 & 2.88 & 11.7 & 1.39 & 25.7 & 5.62 & 20.5 & & 16.4 & 33.7 \\
\hline $\mathbf{P b}$ & $\mathbf{s}$ & 8.5 & 1.83 & 3.67 & 1.0 & 3.88 & 3.73 & 4.38 & 1.61 & 2.34 & & 4.17 & 0.83 \\
\hline & $\mathbf{t}$ & 13.8 & 3.19 & 6.24 & 0.94 & 8.19 & 7.52 & 8.24 & 3.14 & 5.92 & & 17.4 & 12.2 \\
\hline Se & $\mathbf{s}$ & 1.14 & 1.61 & 7.90 & 3.30 & 4.77 & 1.30 & 8.91 & 1.41 & 6.45 & & 3.46 & 2.93 \\
\hline & $\mathbf{t}$ & $1.14^{\mathrm{b}}$ & 1.61 & $17.1^{\mathrm{a}}$ & 5.34 & $5.43^{b}$ & 1.97 & $21.4^{\mathrm{a}}$ & 2.55 & 10.8 & & $4.86^{\mathrm{b}}$ & 5.33 \\
\hline Zn & $\mathbf{S}$ & 32.5 & 11.0 & 42.4 & 15.7 & 74.8 & 2.69 & 61.5 & 12.0 & 56.3 & & 71.0 & 19.3 \\
\hline & $\mathbf{t}$ & 50.1 & 18.3 & 78.4 & 23.0 & 109 & 7.89 & 93.4 & 14.5 & 89.0 & & 126 & 21.1 \\
\hline B & $\mathbf{s}$ & 60.2 & 33.8 & 254 & 32 & 69.3 & 40.8 & 484 & 128 & 8.68 & & 13.2 & 3.36 \\
\hline & $\mathbf{t}$ & $67.1^{b}$ & 32.5 & $309^{\mathrm{a}}$ & 35 & $81.8^{b}$ & 43.8 & $561^{\mathrm{a}}$ & 147 & 44.1 & & $21.8^{b}$ & 2.92 \\
\hline
\end{tabular}

$\dagger$ USEPA Method $200.2\left(\mathrm{HNO}_{3}-\mathrm{HCl}\right.$ digestion $)$.

$\mathrm{t}=$ shoot concentration; $\mathrm{t}=$ total concentration $($ shoot + root $)$.

* Only one loblolly pine harvested from this plot.

${ }^{\mathrm{a}, \mathrm{b}}$ Significant differences for $\mathrm{B}(\mathrm{P}=0.0002, \mathrm{~F} 19.04)$ and for $\mathrm{Se}(\mathrm{P}=0.0022, \mathrm{~F}=9.82)$

** Planted in an uncontaminated area $(\mathrm{n}=2)$.

Table 12. Biomass and species richness of naturally seeded grasses and weeds on the 488-D basin.

\begin{tabular}{|lcccc|} 
Surface Treatment & Block & Biomass $\left(\mathbf{g} / \mathbf{~ m}^{\mathbf{2}}\right)^{*}$ & Standard Deviation & Number of Species \\
\hline Topsoil & A & 123.1 & 43.5 & 11 \\
Topsoil & A & 139.7 & 55.8 & 10 \\
Ash & A & 2.9 & 4.3 & 1 \\
Apatite & A & 0.3 & 0.4 & 2 \\
Apatite & A & 7.7 & 13.4 & 14 \\
Topsoil & B & 86 & 62.4 & 10 \\
Topsoil & B & 179.9 & 16.2 & 1 \\
Ash & B & 0.2 & 0.3 & 1 \\
Mulch & B & 0.8 & 1.5 & 10 \\
Topsoil & C & 119.8 & 22.9 & 1 \\
Topsoil & C & 173.6 & 59.3 & 1 \\
Ash & C & 1.7 & 2.7 & 11 \\
Mulch & C & 11.9 & 20.6 & \\
Native Soil & & & 9.7 & \\
\hline
\end{tabular}

$†$ Sampled August 2001.

$*(\mathrm{n}=3) 1 \mathrm{~m}^{2}$ sampling plots within a treatment plot.

\section{Hydrology and Soil Moisture}

A tipping bucket on the 488-D ash basin recorded rainfall quantity for the site (Table 13). Throughout the study period, the Central Savannah River Region was under the influence 
of a prolonged drought. As such, monthly rainfall quantities that were greater than the 50year average for SRS were observed only twice (March and June 2001) (Figure 16).

Potential evapotranspiration from the study site was estimated using the Penman equation (Penman, 1956) with data from the SRS N-area weather tower. The equation indicated an evaporative demand of $2797.4 \mathrm{~mm}$ for the 20-month period, which would suggest a substantial deficit of water to the basin (Figure 17). In fact, the calculated ET is almost double that of the input water. Piezometers and monitoring wells in the upper two meters of the basin material reflected this condition as they remained dry throughout the twoyear study period. Unfortunately, the influence of ripping on hydraulic conductivity could not be ascertained because the medium was in an unsaturated state throughout the study period and ponding (or perched water) from rain events was not detectable using these instruments. In addition, the drought may have contributed to seedling mortality directly (aestivation), or indirectly through the formation of evaporative salts as described earlier.

Table 13. Monthly rainfall at the 488-DAB during study period.

\begin{tabular}{|lcccccccccc|ccc|} 
& Jan & Feb & Mar & Apr & May & Jun & Jul & Aug & Sep & Oct & Nov & Dec \\
Month & & & & & & & & & & & \\
\hline & $\mathrm{mm}$ & $\mathrm{mm}$ & $\mathrm{mm}$ & $\mathrm{mm}$ & $\mathrm{mm}$ & $\mathrm{mm}$ & $\mathrm{mm}$ & $\mathrm{mm}$ & $\mathrm{mm}$ & $\mathrm{mm}$ & $\mathrm{mm}$ & $\mathrm{mm}$ \\
2001 & & 53.8 & 233.5 & 32.4 & 91.7 & 166.1 & 55.6 & 79.7 & 84.0 & 4.5 & 28.4 & 14.4 \\
2002 & 60.9 & 10.9 & 35.5 & 40.3 & 41.4 & 39.6 & 117.9 & 112.5 & 87.9 & & & \\
$1952-$ & 106.6 & 109.2 & 127.0 & 82.6 & 93.7 & 115.8 & 130.8 & 123.7 & 103.6 & 73.9 & 66.3 & 88.1 \\
2001 .* $^{*}$ & & & & & & & & & & & & &
\end{tabular}

*Long-term rainfall data obtained from SRS A-Area.

(mm)

Rainfall Deviation from SRS Average

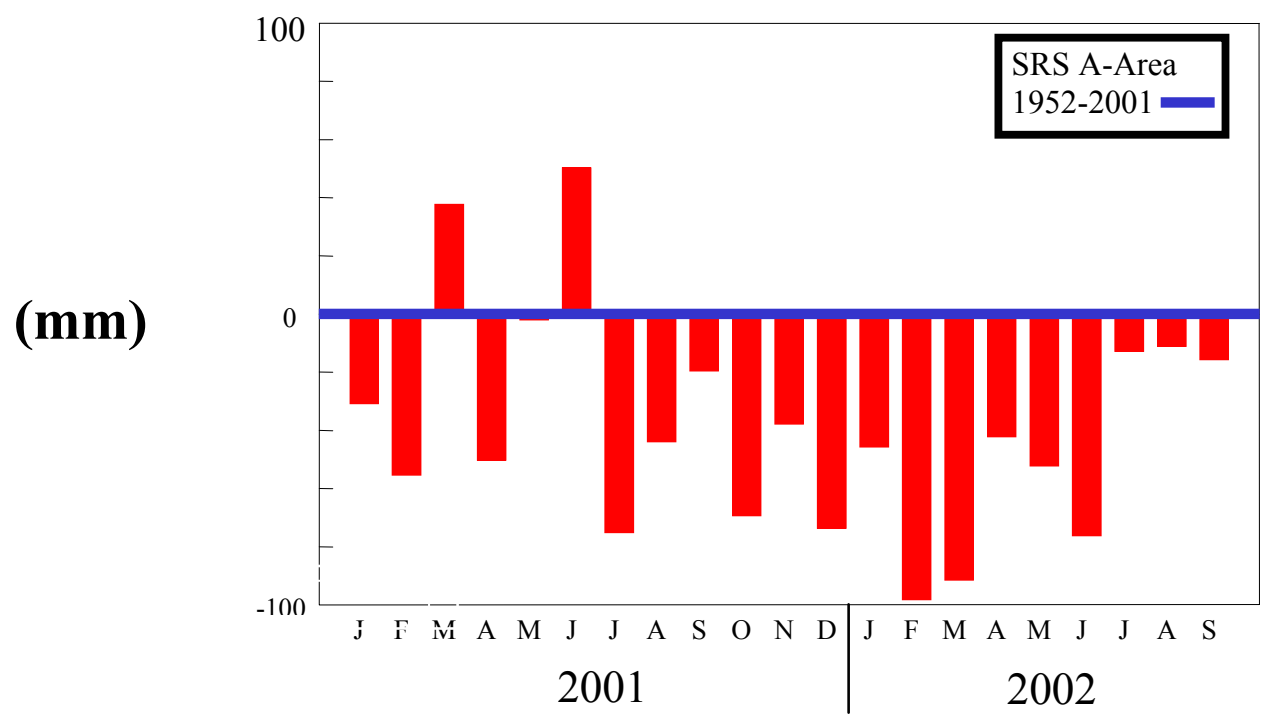

Figure 16. Deviation of monthly rainfall from January 2001 through September 2002 as compared to the 50 year average. 


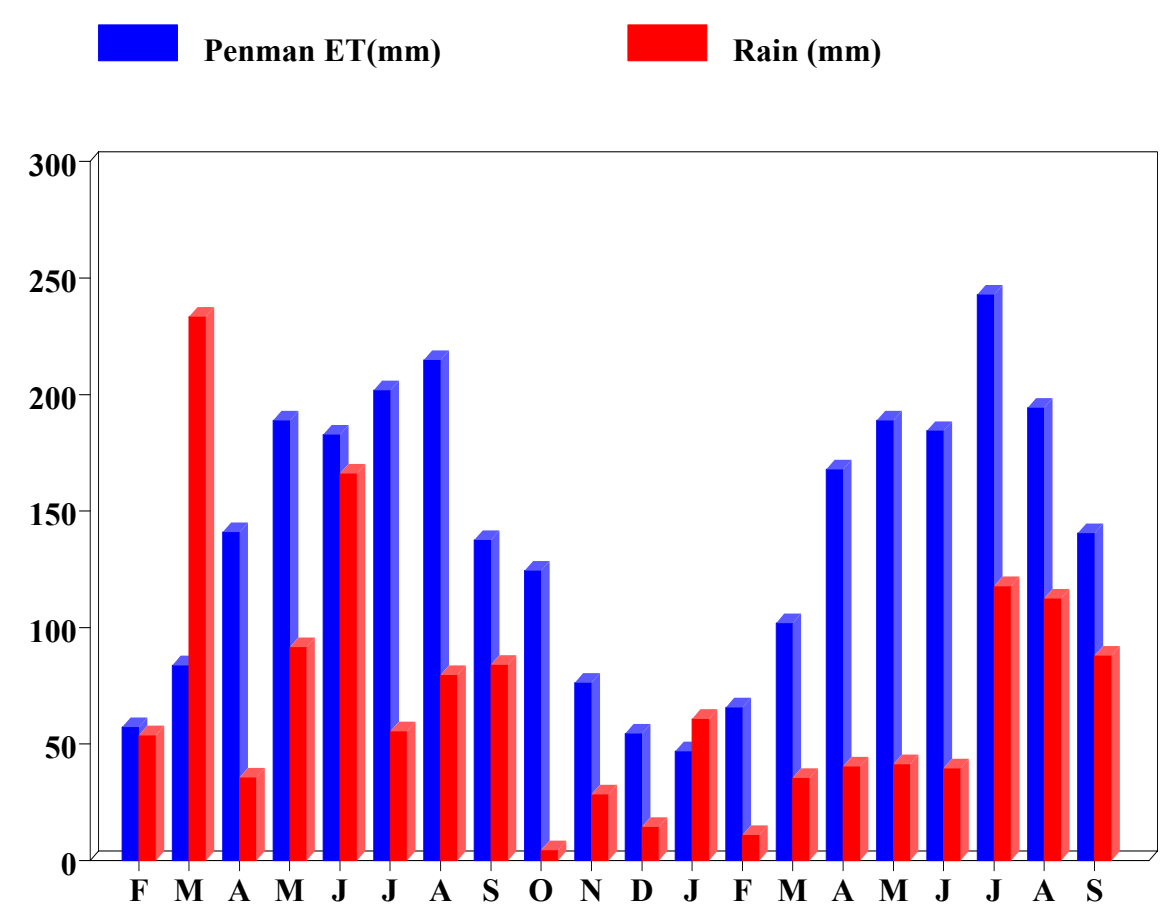

Figure 17. SRS monthly rainfall versus evapotranspiration fromFebruary 2001 through September 2002.

Monthly ET as calculated by the Hargreaves-Samani equation was generally greater than that obtained by any other scenario. Given that this equation uses temperature as the only input variable, an overestimation of actual ET is probable. The reference ET (N-area) generally had the highest summer ET for those calculated with the modified PenmanMonteith (Figure 18). In January and February, however, the two scenarios that contained conifers for the vegetation species of concern were slightly higher. Given that the crop coefficient for Pinus remains relatively high during the winter, as compared to the grass system, this outcome was not surprising. In all cases, incorporation of a vegetative species (grass or pine) resulted in a higher utilization of water over that of the bare soil, which supports the concept of establishing a vegetative cover to minimize recharge and runoff on the 488-D basin. It is also noteworthy that the forested scenario results in an enhanced utilization of water over that of the grass cover (1231 vs. $887 \mathrm{~mm}$ ET during the nine month period). 


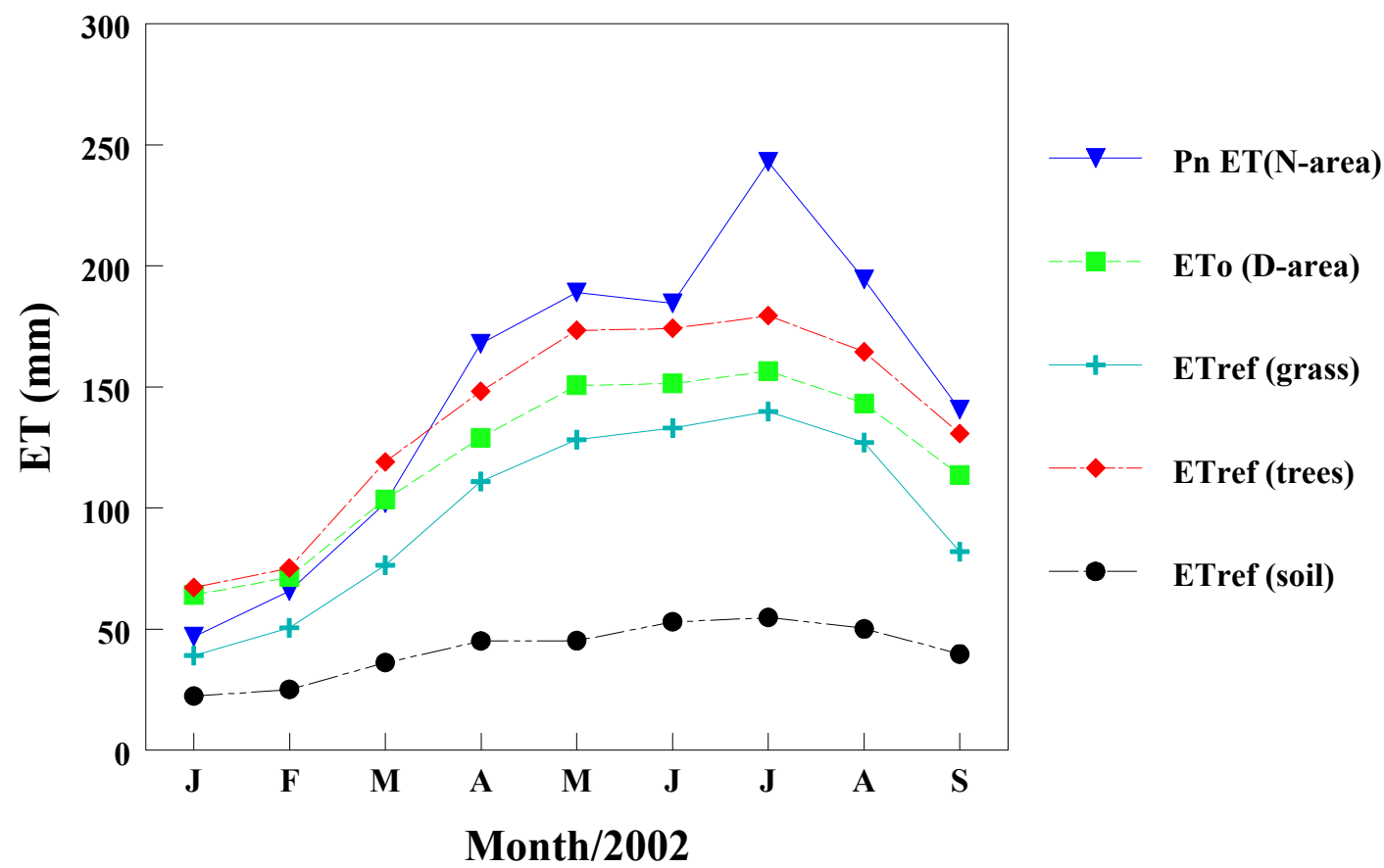

Figure 18. A graphical comparison of projected evapotranspiration rates on the 488-D ash basin for the period January - September, 2002.

An examination of data from the soil moisture sensors initially revealed some interesting trends with respect to water percolation in the basin, and response to rain events. Soil moisture content determined by the TRIME TDR sensor was evaluated on a monthly basis, whereas the ADCON system provided measurements at 15 min intervals. As such, the TRIME provided an overall pattern with respect to the degree of saturation with depth, while the ADCON provided an opportunity to observe dynamic change in response to climatic events. A TRIME sensor located at a reference site (recently harvested bare soil) provided an initial background moisture curve typical for a native soil on the SRS (Figure 19). For the period of March - September 2001, the reference site's surface soil exhibited soil moisture contents of approximately $15 \%$. This level was fairly consistent at the 25 and $55 \mathrm{~cm}$ depths throughout the studied period. Soil moisture increased on this site by approximately $10 \%$ in the deeper profiles $(135$ and $175 \mathrm{~cm})$. 


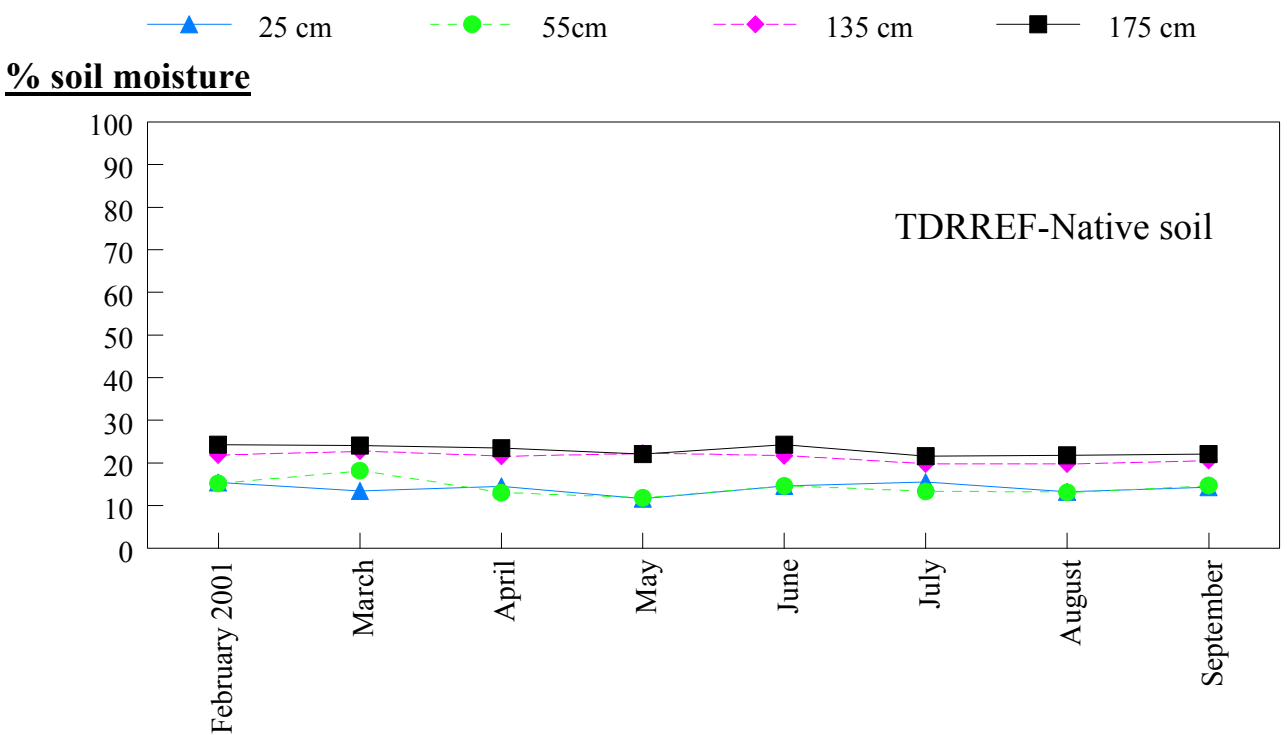

Figure 19. Soil moisture content from the TRIME sensor at various soil depths in a noncontaminated reference soil in 2001.

Soil moisture patterns from the ash basin differed greatly with respect to the reference soil. Surface moisture contents obtained from the TRIME were greater than that observed in the native soil. In addition, the instrument showed incongruent saturation curves with depth, which suggested the presence of perched water tables. The compacted nature of the basin material was conducive for the formation of such zones. The control TRIME sensor located in an undisturbed and un-vegetated area on the basin exhibited surface moisture contents near 30\% (Figure 20). The moisture content then decreased with depth $(50$ and $100 \mathrm{~cm}$ ) by approximately $10 \%$. At $200 \mathrm{~cm}$, however, soil moisture content was near saturation. Based upon this information, the presence of a restrictive layer just below the surface may be likely. 


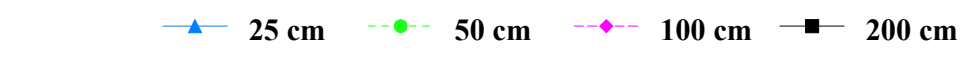

\section{\% soil moisture}

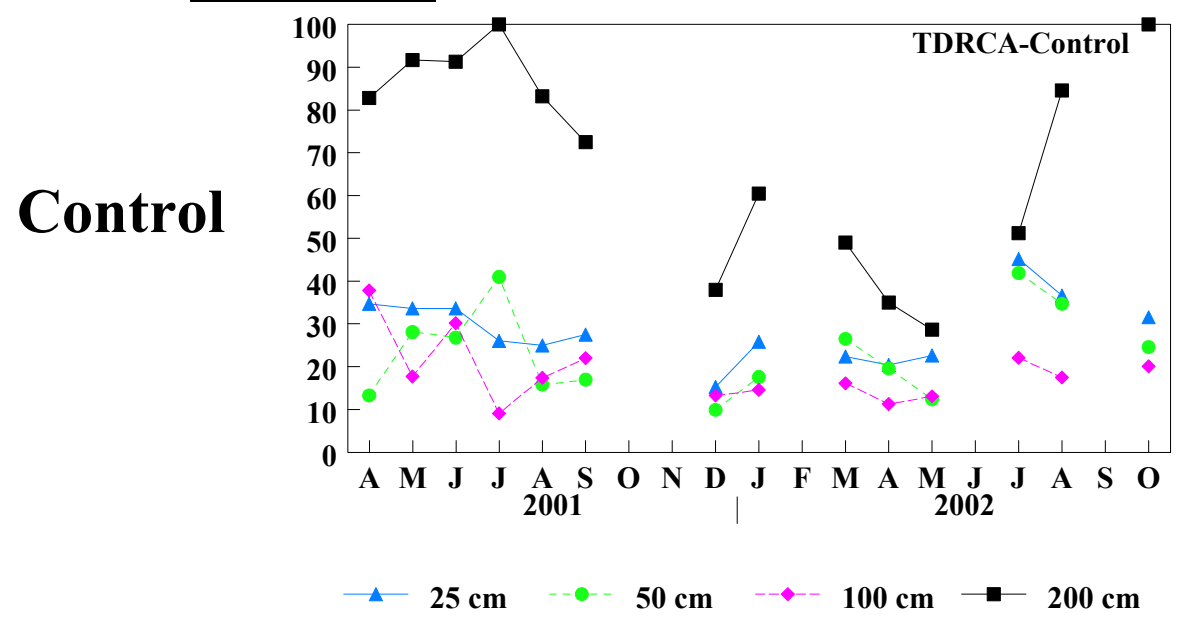

\section{Topsoil}
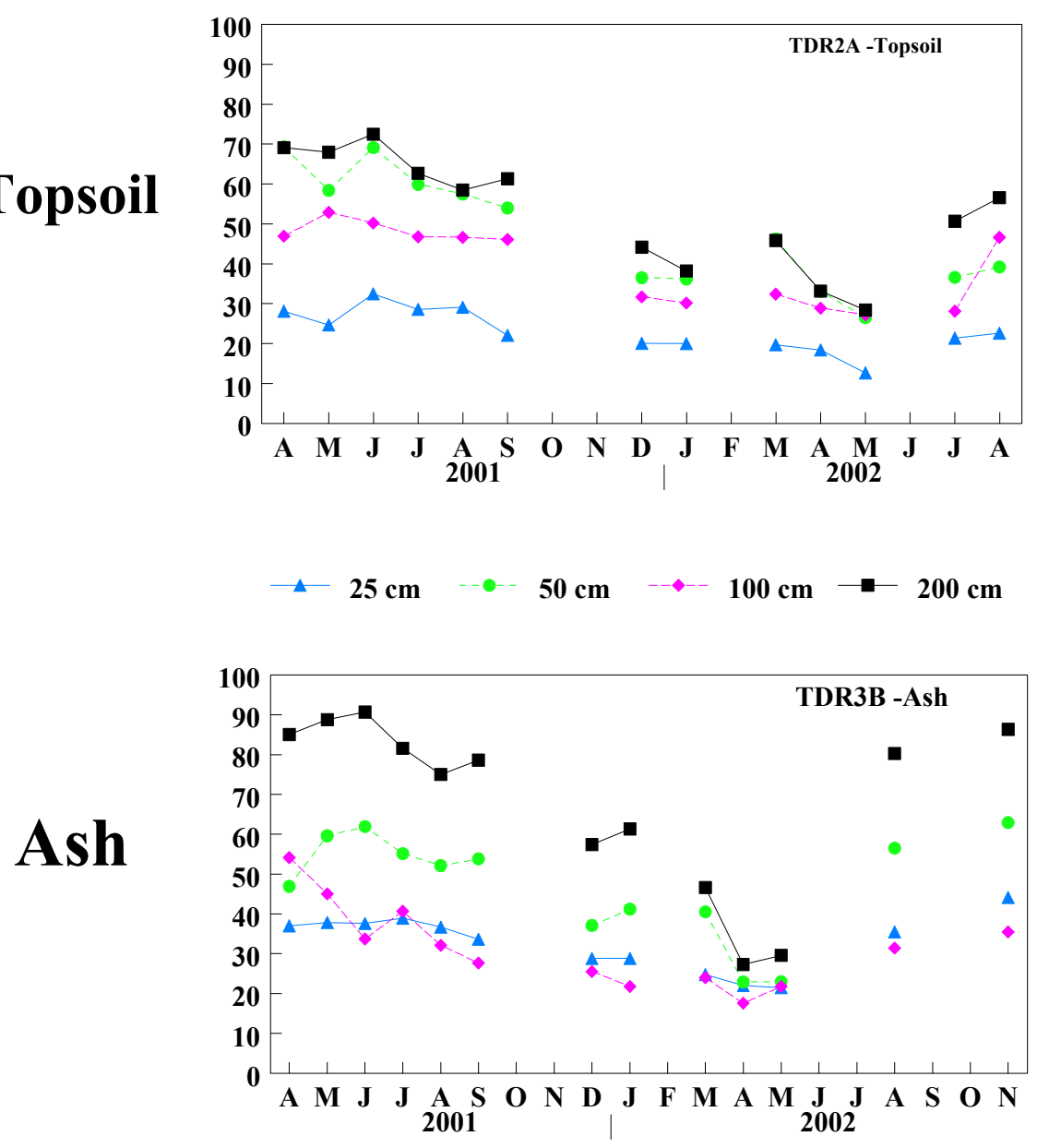

Figure 20. Soil moisture content at 25, 50, 100, and $200 \mathrm{~cm}$ depths as detected by the TRIME TDR sensors in the Ash, Topsoil and Control plots on the 488-D basin. 
The TRIME moisture sensors located within the planted area (Ash and Topsoil plots in block A) displayed lowest moisture readings than the control at the surface level (Figure 20). The topsoil cover exhibited the lowest moisture contents, which is likely attributable to water utilization via the weeds and planted species, particularly in 2002. Oddly, moisture content was higher in the $50 \mathrm{~cm}$ zone than that observed in the $100 \mathrm{~cm}$ zone in both plots. It is possible that a restrictive layer similar to a plow-pan was developed during the ripping process at the one-meter level. The ripping activity was performed to break compaction and promote infiltration, but the extent of the tillage was restricted to the upper part of the profile. Thus, water may move freely through the plowed zone and stop (or slow) at the plowed/unplowed interface. Similar instances have been reported elsewhere by Barton and Karathanasis (2002).

A moisture distribution curve for the topsoil and control sites was developed using average TRIME values for the period January through August 2002 (Figure 21). Average surface $(0-5-\mathrm{cm})$ moisture contents were obtained gravimetrically in the laboratory using core samples from the basin. The moisture content at the $300-\mathrm{cm}$ depth was determined gravimetrically from a soil sample collected in June 2002. The saturation zone was determined using well data provided by WSRC. The moisture distribution curve for the sites clearly shows the presence of a perched zone as described above (Figure 21). In addition, the impact of the vegetation is notable in the upper part of the profile. The whole tree harvesting indicated that the rooting zone was most prominent in the upper 50 $\mathrm{cm}$ of the basin (Table 9). As such, the impact of the vegetation on soil moisture content, at this point in time, would likely occur in that zone. The difference in average soil moisture between the control and topsoil plots during the eight-month period of 2002 was $16.59 \%$. By utilizing a porosity of $\approx 50 \%$ for the basin material (calculated average using cores of $55.95 \pm 16.59)$, the total volume of the basin to $25 \mathrm{~cm}\left(9112.5 \mathrm{~m}^{3}\right)$, and the $16.59 \%$ difference in soil moisture content, the potential loss/utilization of water by the vegetation cover (topsoil plot) was calculated to be more than 9.1 million liters (2.4 million gallons) over that of an unvegetated site (control). Additional modeling work will be performed in the future to further define the influence of the vegetation on the basins hydrology. 


\section{Soil Moisture Distribution Curve}

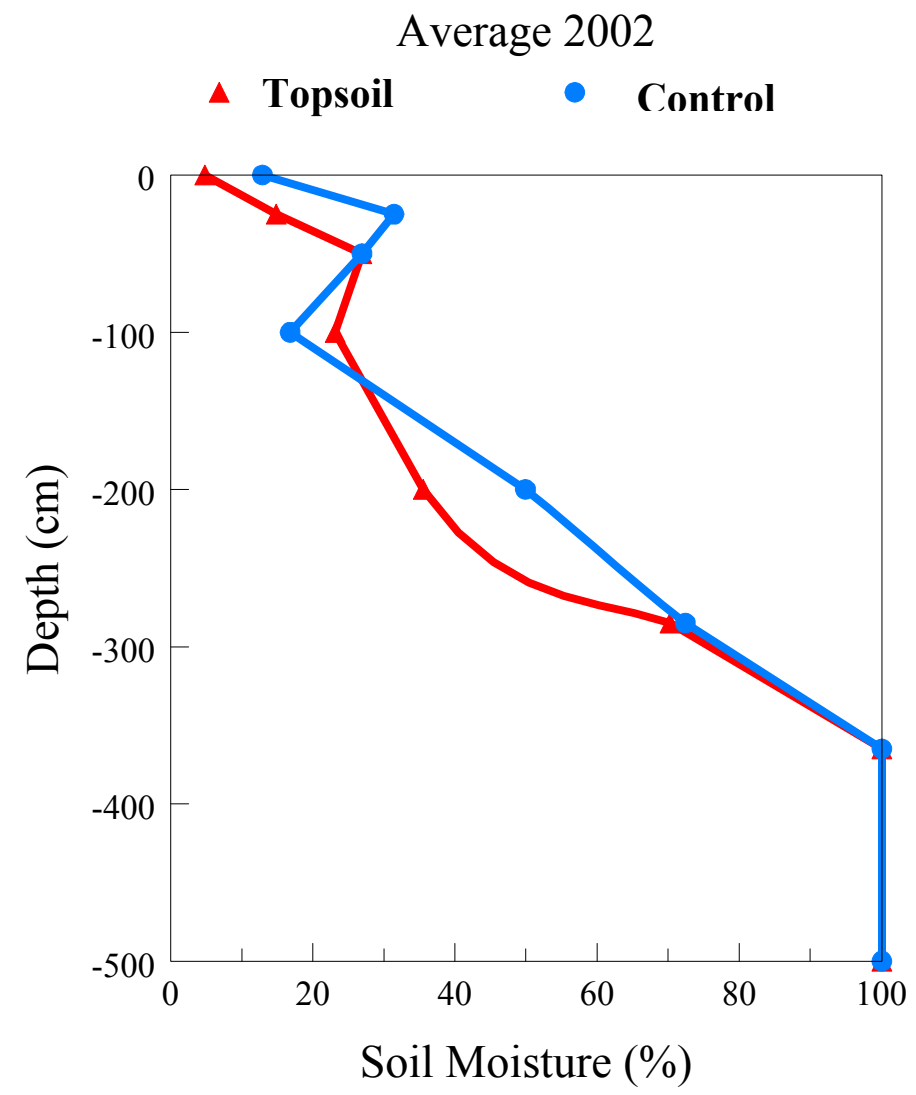

Figure 21. Soil moisture distribution at various depths in the Block A-Topsoil and Control treatments on the 488-D basin.

The response of the ADCON sensors to changes in soil moisture was inconsistent during the study period. The ADCON units appear to have malfunctioned in response to a snow event during the first week of January 2002 (Figure 22). Interestingly, both instruments showed the same pattern and increase in soil moisture content at the $20 \mathrm{~cm}$ depth on the control plot during this event, but gravimetric calculations do not support the high moisture levels recorded. It is possible that the sensors cracked due to the freezing conditions. Sensors on the topsoil and ash plots at $20-\mathrm{cm}$ were not impacted by the freezing conditions, but their reliability is questionable given that soil moisture conditions showed a gradual increase while the soil moisture deficit was increasing in response to the drought (Figures 16 and 23). High salinity and electrical conductivity (EC) have been shown to result in erroneously high readings with TDR and FDR instruments (Dasberg and Dalton, 1985; Nadler et al., 1999). It is likely that the soil moisture increase recorded by the ADCON sensors was actually an increase in EC caused by the formation of evaporative salts. The TRIME units, on the other hand, responded accordingly to the drought conditions and also agreed considerable well $\left(r^{2}=0.73\right)$ with samples collected periodically over the eight-month period and determined gravimetrically (Figure 24). 

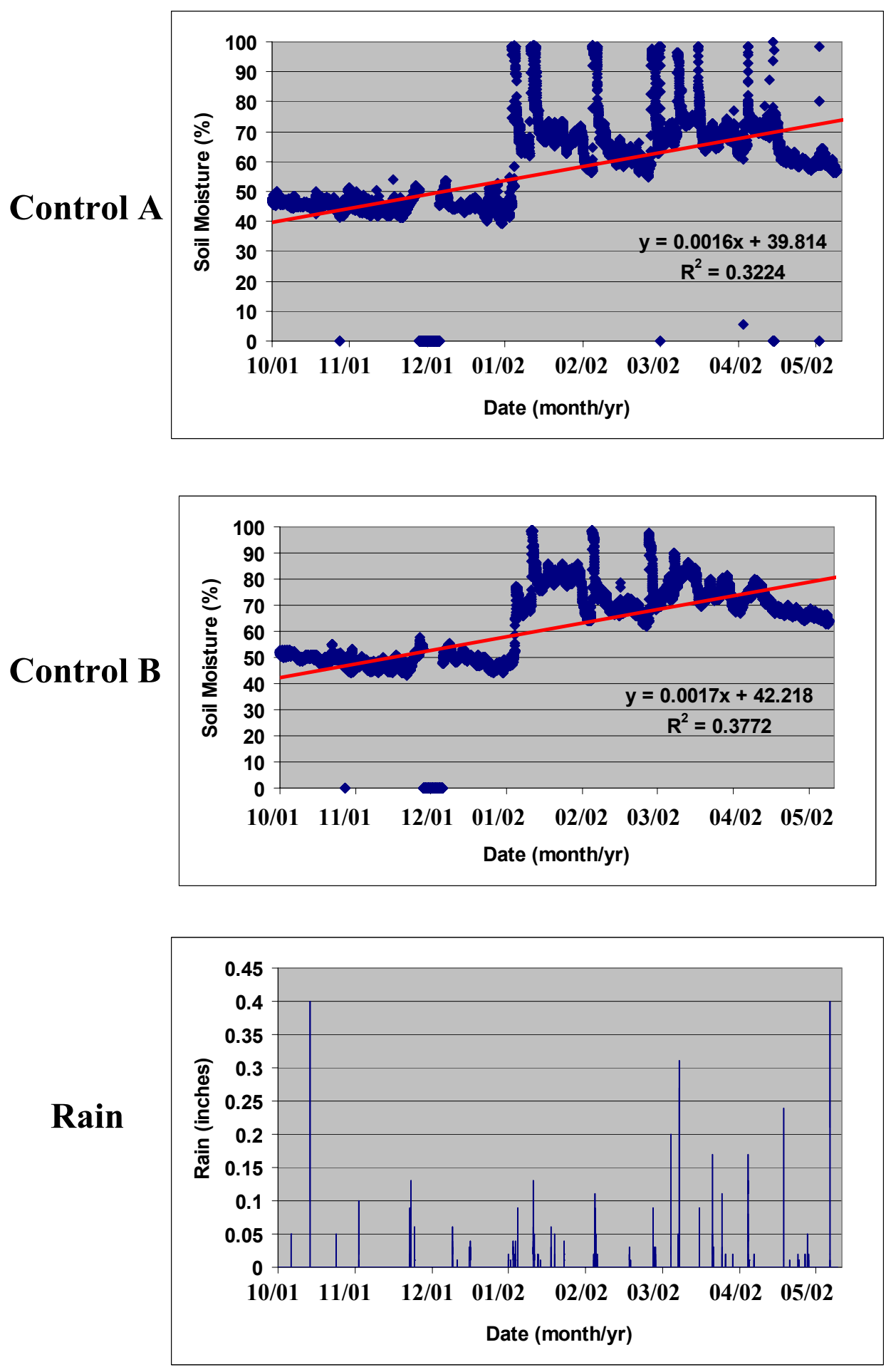

Figure 22. Soil moisture in the control plots as measured by the ADCON sensors. 

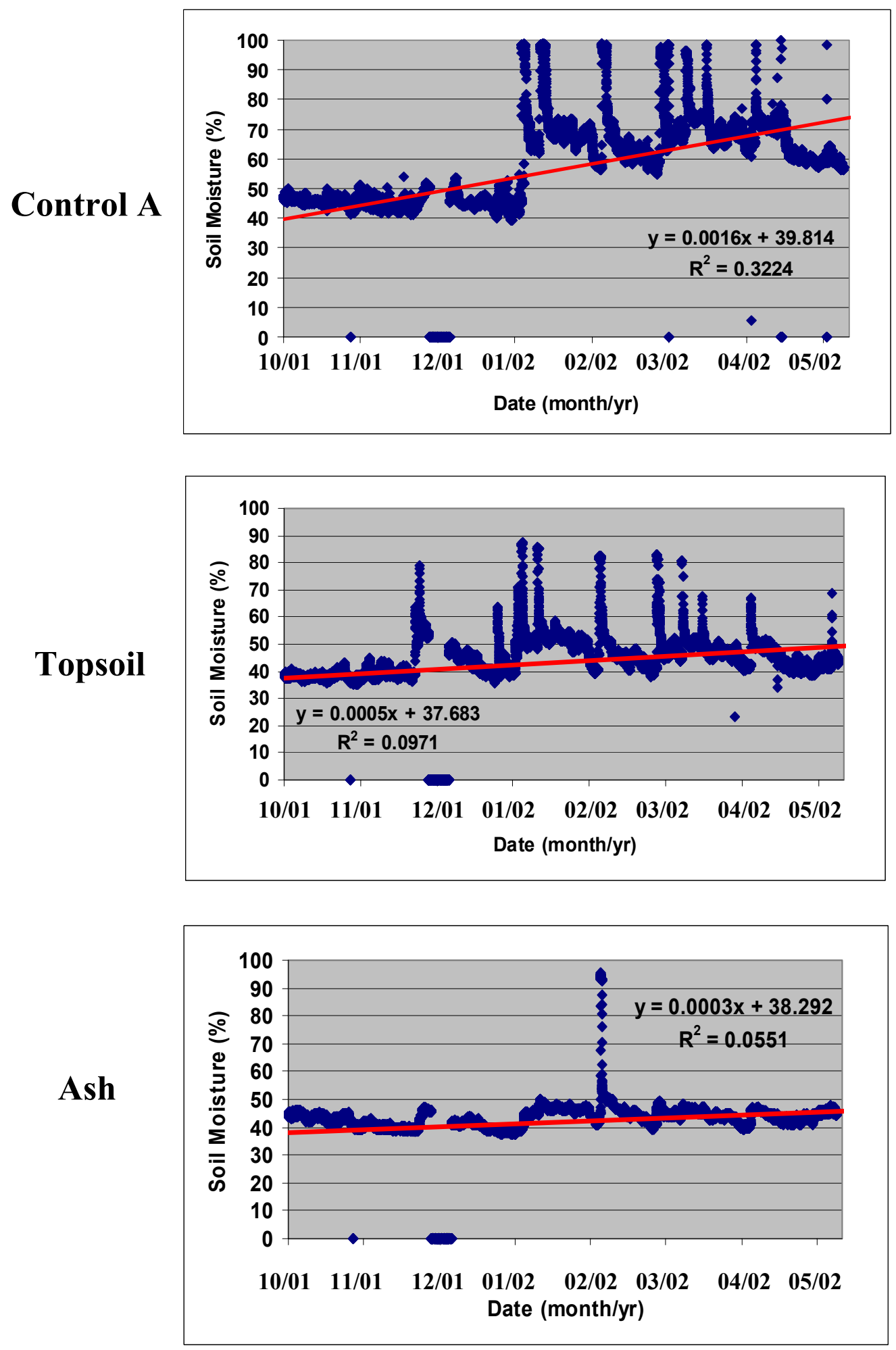

Figure 23. Soil moisture in the Ash, Topsoil and Control plots as measured by the ADCON sensors. 


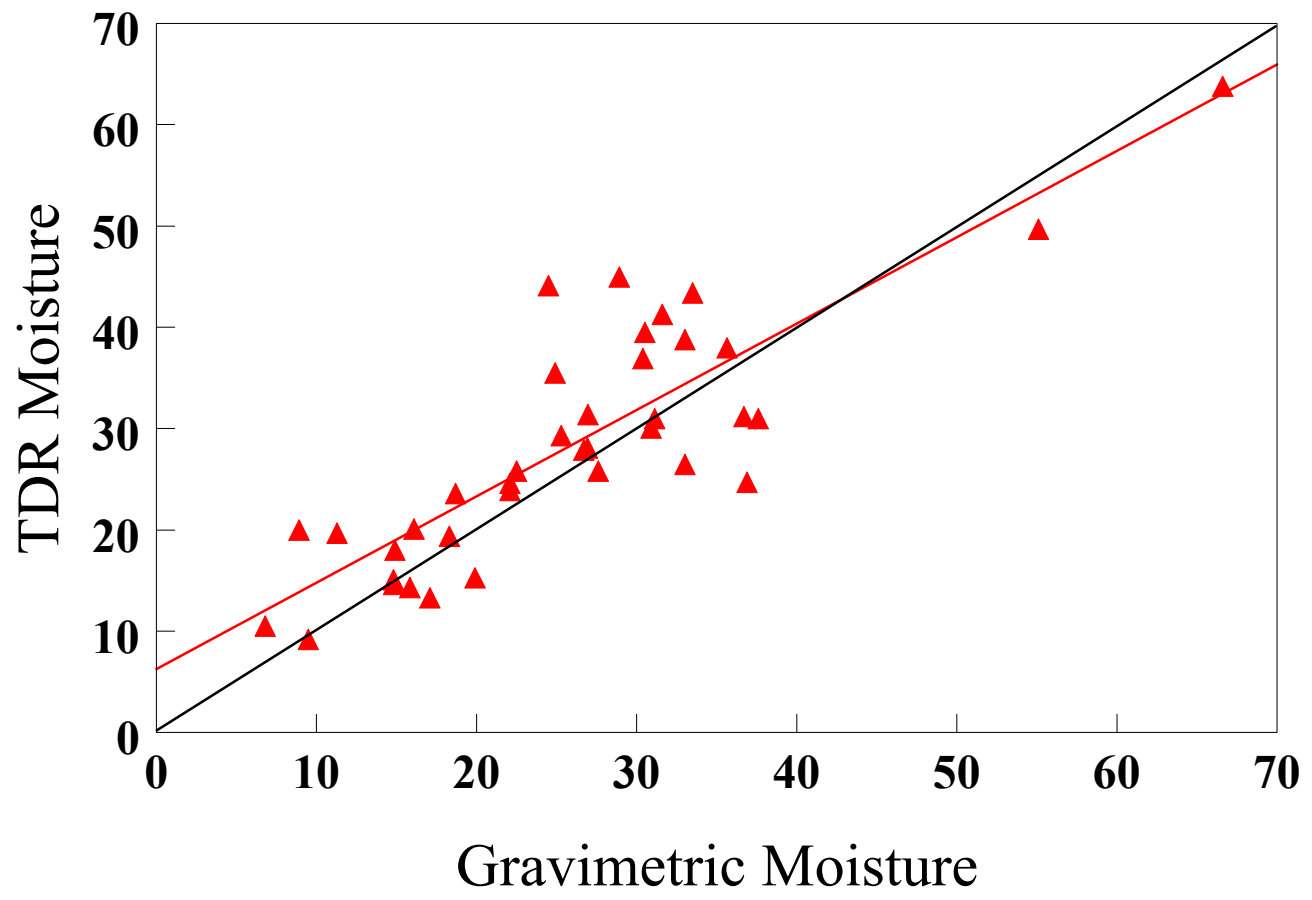

Figure 24. Comparison of the TRIME TDR measurement and gravimetric water content for sediments taken during several sampling events and at various depths on the 488-D basin .

It should also be noted, however, that the ADCON sensors near the surface were useful in determining potential runoff from rain events. An event that occurred on April 10, 2002 resulted in a $\approx 30 \%$ increase in moisture content at the 20 -cm depth in the topsoil plot, followed by a gradual decrease over the next two days (Figure 25). Soil moisture at the 20 -cm depth in the control plot showed little response to the event, which indicated that the precipitation did not infiltrate into the basin material and is either perched on the surface or was transported to the ponded area on the west end of the basin via surface flow. 


\section{Moisture Response to Rain Event}

\section{Control}

Topsoil

Rain

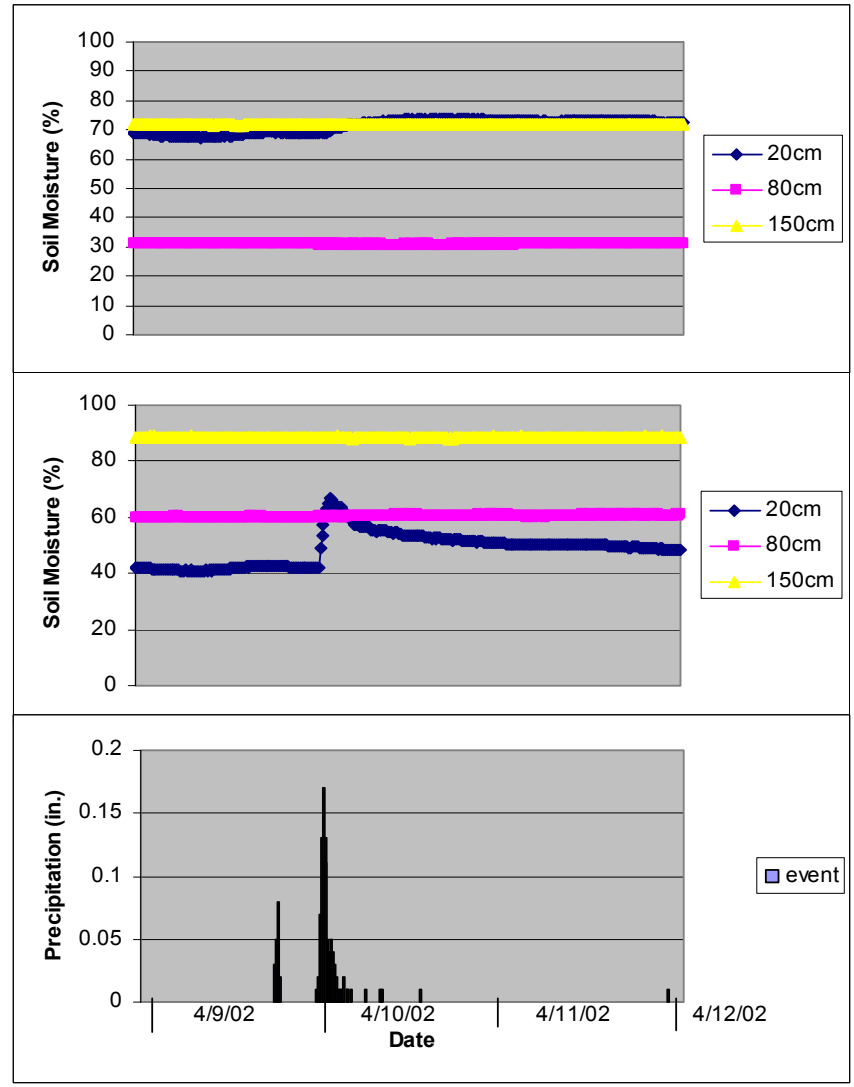

Figure 25. Soil moisture content and response to a rain event as detected by the ADCON sensor at various soil depths on topsoil and control plots at the 488-D basin.

\section{Water Quality}

Bi-weekly water samples were collected from three locations on and adjacent to the 488D ash basin from June 1999 to September 2000 and again in June of 2001 and 2002 (Table 15). Average $\mathrm{pH}$ values from the three locations were consistently in the 2.5 to 3.5 range. Samples from the surface pond and seepage from the ponded area (pipe leak) contained high concentrations of $\mathrm{Al}, \mathrm{Fe}$, and sulfate, which is characteristic of acidic drainage from mining sites and coal combustion waste areas (Evangelou, 1995). Samples collected from the kill zone (area adjacent to the northern berm) also exhibited these constituents, but at a slightly lower concentration. An outfall from the D-area powerhouse contributes uncontaminated water to the kill zone area and has likely produced a dilution effect. Iron in the surface pond was primarily in the ferric $\left(\mathrm{Fe}^{3+}\right)$ oxidation state, while ferrous iron $\left(\mathrm{Fe}^{2+}\right)$ dominated samples from the pipe leak. The iron oxidation provides information on the origin of the water. Drainage in the pond likely originates from surface oxidation of pyrite and subsequent runoff across the gently sloping surface of the basin. High compaction of the basin sediments (Table 8 ) likely promotes these actions by limiting infiltration and maximizing contact of the basin material with oxygenated 
precipitation. The lowest point in the surface topography of the basin is the ponded area at the west end. Once drainage was collected in that location seepage/leakage occurs through the sediment and ultimately through the berm. As the water slowly perked through the basin sediments, oxygen diffusion was likely reduced and microbial consumption of oxygen increased. Consequently, $\mathrm{Fe}^{3+}$ was reduced to $\mathrm{Fe}^{2+}$ and a slight rise in $\mathrm{pH}$ occurred.

Table 14. Average surface and vadose water quality characteristics from the 488-D Ash Basin $\uparrow$.

\begin{tabular}{|c|c|c|c|c|}
\hline Parameter & Surface Pond & Pipe Leak & Kill Zone: & AVG $200 \mathrm{~cm}$ Lysimeter * \\
\hline $\mathbf{n}=$ & 42 & 52 & 56 & 17 \\
\hline pH (su) & $2.71(0.23)$ & $3.16(0.29)$ & $2.84(0.23)$ & $2.49(0.64)$ \\
\hline $\mathrm{Al}\left(\mathrm{mg} \mathrm{L}^{-1}\right)$ & $82.9(112.7)$ & $153.3(93.5)$ & $29.7(66.3)$ & $831.5(740.2)$ \\
\hline $\operatorname{As}\left(\mathrm{mg} \mathrm{L}^{-1}\right)$ & $0.22(0.65)$ & BDL & BDL & $2.80(5.65)$ \\
\hline $\mathrm{Ca}\left(\mathrm{mg} \mathrm{L}^{-1}\right)$ & $100.4(42.8)$ & $123.6(30.1)$ & $53.6(60.7)$ & $350.7(133.8)$ \\
\hline $\mathrm{Cd}\left(\mathrm{mg} \mathrm{L}^{-1}\right)$ & BDL & BDL & BDL & $0.92(0.58)$ \\
\hline $\operatorname{Cr}\left(\mathrm{mg} \mathrm{L}^{-1}\right)$ & $0.04(0.04)$ & $0.02(0.03)$ & BDL & $0.48(0.79)$ \\
\hline $\mathrm{Cu}\left(\mathrm{mg} \mathrm{L}^{-1}\right)$ & $0.15(0.15)$ & $0.07(0.04)$ & $\mathrm{BDL}$ & $7.49(14.3)$ \\
\hline $\mathrm{Fe}\left(\mathrm{mg} \mathrm{L}^{-1}\right)$ & $181.3(245.1)$ & $213.8(72.3)$ & $57.0(58.1)$ & $7460.1(3971.1)$ \\
\hline $\mathbf{K}\left(\mathbf{m g ~ L}^{-1}\right)$ & $2.64(2.38)$ & $12.8(4.6)$ & $6.28(4.21)$ & BDL \\
\hline $\operatorname{Mg}\left(\mathrm{mg} \mathrm{L}^{-1}\right)$ & $33.4(72.5)$ & $43.7(26.8)$ & $23.9(39.8)$ & $431.1(195.2)$ \\
\hline $\operatorname{Mn}\left(m g L^{-1}\right)$ & $1.56(2.83)$ & $2.14(0.66)$ & $1.95(2.25)$ & $41.3(16.1)$ \\
\hline $\mathrm{Na}\left(\mathrm{mg} \mathrm{L}^{-1}\right)$ & $5.83(9.22)$ & $9.21(4.69)$ & $25.1(17.8)$ & $31.2(16.6)$ \\
\hline $\mathrm{Ni}\left(\mathrm{mg} \mathrm{L}^{-1}\right)$ & $0.15(0.26)$ & $0.31(0.09)$ & $0.05(0.06)$ & BDL \\
\hline $\operatorname{Se}\left(\mathrm{mg} \mathrm{L}^{-1}\right)$ & BDL & $0.01(0.01)$ & BDL & BDL \\
\hline $\mathrm{Zn}\left(\mathrm{mg} \mathrm{L}^{-1}\right)$ & $0.29(0.29)$ & $0.48(0.18)$ & $0.18(0.13)$ & $13.5(14.7)$ \\
\hline $\mathrm{SO}_{4}\left(\mathrm{~g} \mathrm{~L}^{-1}\right)$ & $1.41(1.43)$ & $1.62(0.43)$ & $0.57(0.51)$ & $4.80(1.98)$ \\
\hline $\mathrm{Ba}\left(\mathrm{mg} \mathrm{L}^{-1}\right)$ & $0.04(0.04)$ & $0.04(0.03)$ & $0.05(0.05)$ & \\
\hline$B\left(\mathrm{mg} \mathrm{L}^{-1}\right)$ & $0.27(0.13)$ & $0.47(0.34)$ & $0.31(0.05)$ & \\
\hline Fe II (\%) & $11.7(15.3)$ & $83.5(16.4)$ & $40.0(20.5)$ & \\
\hline
\end{tabular}

$\dagger$ Standard deviation in parenthesis.

†Surface water samples collected bi-weekly from July 1999 - September 2000 and in June 2001 and 2002.

* Vadose samples collected quarterly from three lysimeters at 200-cm depth during the period April 2001 - October 2002.

Water samples collected from three lysimeters at a depth of $200 \mathrm{~cm}$ exhibited a lower $\mathrm{pH}$ and higher elemental composition than the surface waters (Table 15). Not only were the concentrations higher in the lysimeters, but levels were generally an order of magnitude greater for most parameters analyzed. Given the low permeability of the substrate material and high pyrite content of the substrate, the high concentrations were not unexpected. Water likely stayed in close contact with the reactive material for an extended period of time, which allowed for maximum oxidation of the sulfide materials and dissolution of evaporative salts (see Barton et al., 2003 for more detail). As the pore water slowly moved through the sediments, oxygen consumption increased, $\mathrm{pH}$ rose and metals precipitated as discrete minerals within the substrate (Barton et al., 2003). Thus, a significant amount of filtering occurred within the basin prior to release through the berm or below grade.

The influence of the cover on water quality is not clearly evident at this time. Due to the prolonged drought, collection of shallow pore water was difficult to achieve. Fifteen lysimeters at various depths were pumped on a monthly basis for the duration of the study. Of those, only seven samplers yielded water more than twice. The average water 
quality characteristics from those samplers are outlined in Table 16. Samples collected from Block A - topsoil at the 15 and $30 \mathrm{~cm}$ depths were relatively clean as compared to the surface water or $200 \mathrm{~cm}$ lysimeter samples. Both sample depths in the Block Atopsoil plots exhibited neutral pHs, low Fe and $\mathrm{Al}$ content, and negligible trace element concentrations. Samples collected from Block C - topsoil at the 15 and $30 \mathrm{~cm}$ depths, however, exhibited a chemistry that was more similar to that of the surface waters. Both samplers from Block $\mathrm{C}$ yielded sample that would exceed discharge water quality standards for Fe and Mn from active mine sites (Code of Federal Regulations, 1996). The $30 \mathrm{~cm}$ lysimeter from this Block is also out of compliance for sulfate and $\mathrm{pH}$. As described for the $200 \mathrm{~cm}$ lysimeters above, the lack of ripping and subsurface amendment in Block $\mathrm{C}$ did not allow for the infiltration of water or penetration of roots. As such, contact of rainwater to the basin material was maximized and water quality deterioration ensued. As a consequence, plant roots were subjected to the adverse conditions and high seedling mortality resulted. The water chemistry in Block A, in the near-surface rooting zone, was not deteriorated and resulted in low seedling mortality and high growth characteristics.

Table 16. Average water quality characteristics from lysimeters on the 488-D Ash Basin between April 2001 and October 2002†.

\begin{tabular}{|c|c|c|c|c|c|c|c|}
\hline Parameter & $\mathrm{T}-15-\mathrm{A}+$ & T-30-A & $\mathrm{T}-15-\mathrm{C}$ & T-30-C & $200 \mathrm{~cm}-\mathrm{A}$ & $200 \mathrm{~cm}-\mathrm{B}$ & $200 \mathrm{~cm}-\mathrm{C}$ \\
\hline $\mathbf{n}=$ & 4 & 4 & 4 & 4 & 5 & 6 & 6 \\
\hline pH (su) & $6.27(0.20)$ & $6.01(0.26)$ & $5.37(2.71)$ & $2.13(0.13)$ & $2.94(0.70)$ & $2.52(0.16)$ & $2.07(0.70)$ \\
\hline $\mathrm{EC}(\mathrm{mS})$ & $3.11(3.11)$ & $3.50(4.13)$ & $5.04(5.87)$ & $7.39(2.45)$ & 35.7 (25.9) & $21.8(6.5)$ & $52.2(20.0)$ \\
\hline $\mathrm{Al}\left(\mathrm{mg} \mathrm{L^{-1 }}\right)$ & $0.50(0.01)$ & $0.59(0.02)$ & $86.1(120.6)$ & $111.5(59.9)$ & $298.1(218.0)$ & $1205.4(932.2)$ & $959.2(715.1)$ \\
\hline $\operatorname{As}\left(\mathrm{mg} \mathrm{L} \mathrm{L}^{-1}\right)$ & $0.02(0.01)$ & $0.03(0.06)$ & $0.13(0.24)$ & $0.08(0.08)$ & BDL & $4.55(9.57)$ & $3.79(3.74)$ \\
\hline $\mathrm{Ca}\left(\mathrm{mg} \mathrm{L}^{-1}\right)$ & $243.1(83.8)$ & $284.9(321.9)$ & $257.4(278.2)$ & $1493.6(2050.5)$ & $191.6(40.2)$ & $377.7(83.8)$ & $456.4(85.3)$ \\
\hline $\mathrm{Cd}\left(\mathrm{mg} \mathrm{L}^{-1}\right)$ & $\mathrm{BDL}$ & BDL & $0.01(0.02)$ & $0.10(0.06)$ & $0.53(0.42)$ & $0.78(0.21)$ & $1.34(0.67)$ \\
\hline $\mathrm{Cr}\left(\mathrm{mg} \mathrm{L}^{-1}\right)$ & $0.01(0.01)$ & BDL & $0.04(0.06)$ & $0.11(0.15)$ & $\mathrm{BDL}$ & $1.04(1.19)$ & $0.44(0.50)$ \\
\hline $\mathrm{Cu}\left(\mathrm{mg} \mathrm{L}^{-1}\right)$ & $0.02(0.00)$ & $\mathrm{BDL}$ & $0.80(0.73)$ & $8.42(7.26)$ & $1.73(1.82)$ & $16.3(24.7)$ & $4.98(6.2)$ \\
\hline $\mathrm{Fe}\left(\mathrm{mg} \mathrm{L}^{-1}\right)$ & $1.30(0.80)$ & $1.29(1.44)$ & $27.0(28.6)$ & $882.3(653.2)$ & $4697.2(3833.6)$ & $6039.7(2862.2)$ & $10806.9(2547.8)$ \\
\hline $\mathrm{K}\left(\mathrm{mg} \mathrm{L}^{-1}\right)$ & $186.7(81.6)$ & $85.5(67.3)$ & $251.8(207.7)$ & $22.8(36.2)$ & BDL & $1.64(4.12)$ & $3.56(10.0)$ \\
\hline $\operatorname{Mg}\left(\mathrm{mg} \mathrm{L}^{-1}\right)$ & $91.3(97.9)$ & $157.0(211.2)$ & $76.2(85.6)$ & $182.1(90.9)$ & $323.2(75.9)$ & $325.0(53.8)$ & $603.1(124.7)$ \\
\hline $\operatorname{Mn}\left(\mathrm{mg} \mathrm{L}^{-1}\right)$ & $1.38(1.28)$ & $1.12(1.31)$ & $20.9(29.5)$ & $10.3(7.5)$ & $37.4(10.7)$ & $39.2(13.9)$ & $46.0(22.4)$ \\
\hline $\mathrm{Na}\left(\mathrm{mg} \mathrm{L}^{-1}\right)$ & $37.6(27.8)$ & $39.9(44.1)$ & $60.9(64.7)$ & $9.10(6.29)$ & $28.4(11.0)$ & $36.2(23.1)$ & $29.5(17.3)$ \\
\hline $\mathrm{Ni}\left(\mathrm{mg} \mathrm{L}^{-1}\right)$ & $\mathrm{BDL}$ & $\mathrm{BDL}$ & BDL & $\mathrm{BDL}$ & $\mathrm{BDL}$ & $\mathrm{BDL}$ & $\mathrm{BDL}$ \\
\hline $\mathrm{Pb}\left(\mathrm{mg} \mathrm{L^{-1 }}\right)$ & BDL & BDL & $0.04(0.06)$ & $0.06(0.13)$ & $0.07(0.11)$ & $0.35(0.46)$ & $0.29(0.12)$ \\
\hline $\mathrm{Se}\left(\mathrm{mg} \mathrm{L}^{-1}\right)$ & BDL & BDL & $\mathrm{BDL}$ & $\mathrm{BDL}$ & $\mathrm{BDL}$ & $\mathrm{BDL}$ & $\mathrm{BDL}$ \\
\hline $\mathrm{Zn}\left(\mathrm{mg} \mathrm{L}^{-1}\right)$ & $0.23(0.17)$ & $0.18(0.12)$ & $4.25(5.40)$ & $12.8(13.3)$ & $6.94(0.34)$ & $19.2(24.3)$ & $14.3(11.6)$ \\
\hline $\mathrm{SO}_{4}\left(\mathrm{~g} \mathrm{~L}^{-1}\right)$ & * & $*$ & $*$ & $5.37(3.71)$ & $61.0(15.5)$ & $62.0(21.0)$ & $28.0(2.8)$ \\
\hline
\end{tabular}

$\dagger$ Standard deviation in parenthesis.

$\ddagger \mathrm{T}=$ topsoil cover; \# = depth $(\mathrm{cm}) ; \mathrm{A}, \mathrm{B}, \mathrm{C}$ refer to the planting Block on the basin.

* Insufficient sample volume for analysis.

\section{Gradient Study}

By February 2002 all of the plants on the gradients exhibited yellowing of the needles and signs of severe stress. Subsequently, soil samples were collected from the plots and analyzed at the Clemson Analytical Services laboratory to determine whether or not the plants were suffering any nutrient deficiencies. Soil analysis revealed that the sites were limited with respect to nitrate and phosphorous (Table 17). In addition, the $\mathrm{pH}$ of the material was high for loblolly pine. In an effort to compensate for these deficiencies the seedlings (and rooting zone) were watered with a liquid fertilizer. Initially, the seedlings responded positively to the treatment with some greening and noticeable bud growth, but 
the effects were short term. By April, yellowing of the needles had returned and mortality was evident regardless of the amendment depth in which the seedlings were planted. An examination of the seedlings planted in the native soil plots also showed signs of stress and mortality. Based upon this survey it was determined that the plants were suffering from lack of water due to the regional drought. The rebound exhibited by the seedlings to the fertilizer application was likely a response to the water, not the nutrient. The plots received only $10.9 \mathrm{~mm}$ of rain in February (10\% of the normal rainfall amount) and less than $30 \mathrm{~mm}$ in March (Table 2A). An attempt was made to water the plots again in late April and early May, but the effort was undertaken too late and the damage was too severe. All but a few of the seedlings were dead by June 2002 and the study was discontinued.

Table 17. Soil analysis of the gradient amendments collected 02/20/02.

\begin{tabular}{|lllll|llll|}
\hline Gradient & Cover type & $\mathbf{p H}$ & $\mathbf{N O}_{\mathbf{3}^{-}}$ & $\mathbf{P}^{*}$ & $\mathbf{K}^{*}$ & $\mathbf{M g}^{*}$ & $\mathbf{C a}^{*}$ & $\begin{array}{l}\mathbf{E C} \\
(\mathbf{m S})\end{array}$ \\
\hline A & ash/compost/topsoil & 6.8 & 5 & BDL & 212 & 74 & 599 & 3.4 \\
B & ash/compost & 6.9 & 6 & BDL & 299 & 84 & 615 & 4.2 \\
\hline
\end{tabular}

${ }^{*} \mathrm{mg} / \mathrm{Kg}$

$\mathrm{BDL}=$ below detection

\section{CONCLUSION}

Physical, biological and chemical treatments were applied to an extremely acidic reject coal basin on the Savannah River Site in an attempt to demonstrate the potential use of a vegetative cover as a means for enhanced utilization of rainwater and subsequent nonpoint source water pollution control. Deep ripping, subsurface amendments and surface covers were shown to be essential for the successful establishment of vegetation on the basin. Loblolly and Virginia pine seedlings inoculated with the ectomycorrhizal fungi Pisolithus tinctorius $(\mathrm{Pt})$ and Scleroderma cepa $(\mathrm{Sc})$ withstood the harsh environment of the 488-D basin and grew to levels that exceeded those on an uncontaminated site during the two- year evaluation period. Seedlings located on Block A (ripped and deep amended) in the topsoil plots developed a root system that grew into the basin media without significant adverse effects to the plant. These trees showed no significant nutrient deficiency problems. Trees growing in the flyash and mulch plots of Block A achieved a survival rate greater than $50 \%$, but tissue analysis indicated a potential problem due to boron toxicity. Seedlings on Blocks B and C, regardless of the surface treatment, were likely influenced by lack of subsurface amendments and ripping, respectively, which resulted in poor rooting conditions, high acidity and high mortality. A prolonged regional drought may have contributed to these results by a higher than expected mortality rate in all Blocks due to aestivation and changes to the chemistry of the basin by evaporative salt formation and subsequent acid generation. Water samples from lysimeters in Block $\mathrm{C}$ and in the deeper profile reflected this phenomenon with high acidity, Fe, Mn, Al, sulfate and trace element concentrations. Water quality characteristics of the topsoil plots in Block A were acceptable as was demonstrated by the good growth and survival rates on these plots. The overall influence of the vegetation on 
water quality and quantity is difficult to ascertain at this time because the system is still immature. The full potential of the trees influence on subsurface hydrology will likely not be realized until canopy cover is achieved (approximately 5-7 years). A general decrease in soil moisture content, however, was measured in the rooting zone of plots that were successfully vegetated (Block A - topsoil), which suggests that the potential exists for considerable utilization of water by a vegetative cover.

The establishment of a vegetative cover on the basin will greatly decrease surface runoff of water during precipitation events, which may be a major source of contamination on the site. In addition, the development of a litter layer will likely aid the system over time through the lessening of surface redox, temperature and light conditions, all of which contribute to the oxidation of pyrite. Initially, the quickest way to achieve this type of scenario would involve the planting of both herbaceous and forested species. The herbaceous species may be utilized as a nurse crop to help with the runoff control and as a soil conditioner (i.e. quick development of a litter layer). Ultimately, however, the herbaceous crop will not have as significant an impact on the basin's hydrology as the forested species will through evapotranspiration. Also, long-term cost associated with maintaining a herbaceous cover will also be much higher than that of a forested crop. Given these circumstances, deployment of a vegetative cover on the 488-D basin should be considered as an interim action measure to facilitate the remediation process and to further examine this technique as an alternative to traditional landfill caps.

\section{ACKNOWLEDGEMENTS}

The authors would like to express gratitude to the following for their efforts and contributions to the project: Mark Coleman, USFS; Lee Newman, SREL; Selina Marx, PHC Reclamation; Ed Cordell, PHC Reclamation; Felicia Seay, South Carolina State University; Heather Barkley, University of South Carolina; Julian Singer, SREL; Bob Blundy, WSRC-ER; Cassie Bayer, WSRC-ER and Tim Smail, SRTC. This work was funded by the U.S. Department of Energy-Savannah River Operations Office through the U.S. Forest Service Savannah River (Financial Assistance Award DE-IA09-00SR22188) and to the Savannah River Ecology Laboratory through the University of Georgia Research Foundation, Inc (Financial Assistance Award DE-FC09-96SR18546).

\section{REFERENCES}

Adriano, D.C. 2001. Trace Elements in Terrestrial Environments: Biogeochemistry, Bioavailability and Risks of Metals. Springer, New York. 867 pp.

Allen, R.G., Pereira, L.S., Raes, D., and Smith, M. 1998. Crop evapotranspiration Guidelines for computing crop water requirements. FAO Irrig. and Drain. Paper 56. Food and Agriculture Organization of the United Nations, Rome. pp. 300.

Allen, R.G., L.S. Pereira, D. Raes, and M. Smith. 1999. Crop evapotranspiration: Guidelines for computing crop water requirements. FAO Irrigation and Drainage Paper 56, FAO, Rome. 
Alloway, B.J. 1990. Heavy Metals in Soils. J. Wiley and Sons. New York. 339 pp.

American Public Health Association. 1989. Standard Methods for the Examination of Water and Wastewater, $17^{\text {th }}$ Ed. APHA, Washington, D.C.

Barton, C.D. and A.D. Karathanasis. 2002. A novel method for measurement and characterization of soil macroporosity. Communications in Soil Science and Plant Analysis. 33:1305-1322.

Barton, C.D., L. Paddock, C. Romanek and J. Seaman. 2003. Geochemistry of an abandoned landfill containing coal combustion wastes: Implications for remediation. In K.S. Sajwan et al (eds) Chemistry of Trace Elements in Coal Ash. Kluwer Academic/Plenum Press. New York. (Accepted for Publication).

Belzile, N., S. Maki, Y, Chen, and D. Goldsack. 1997. Inhibition of pyrite oxidation by surface treatment. Sci. of the Total Environ. 196: 177-186.

Bledsoe, L., E.C. Varsa, S.K. Chong, F.J. Olsen, B.P. Klubek, and D.J. Stucky. 1992. The effects of deep tillage on reclaimed mine spoils. pp. 51-58. In R.E. Dunker et al (eds.) Prime Farmland Reclamation. Department of Agronomy-University of Illinois at Urbana-Champaign.

Bouwer, H. 1989. The Bouwer and Rice slug test- an update. Ground Water. 27: 15-20.

Campbell, R. 2001. Reference sufficiency ranges for plant analysis in the southern region of the U.S. Southern Cooperative Series Bulletin, SCSB \# 392. North Carolina, Department of Agriculture. Raleigh, NC.

Cnova, J.L. 1999. Elements in South Carolina inferred background soil and sediment samples. South Carolina Geology. 41:11-25.

Code of Federal Regulations. 1996. Part 434, Coal mining point source category BPT, BAT, BCT limitations and new source performance standards. Office of Federal Register, Washington, DC.

Dasberg, S., and F.D. Dalton. 1985. Time-domain reflectometry field measurements of soil water content and electrical conductivity. SSSAJ. 49: 293-297.

Dobson, M.C., and A.J. Moffat. 1993. The Potential for Woodland Establishment on Landfill Sites. HSMO Press.

Ellis, R.J., J.J. Hanway, G. Holmgren, D.R. Keeny, and O.W. Bidwell. 1992. Sampling and Analysis of Soils, Plants, Wastewaters, and Sludge-Suggested Standardization and Methodology. Agricultural Exp. Station, Kansas State Unversity, Manhattan, Res. Pub. 170 North Central Regional Pub. 230. 
Evangelou, V.P. 1995. Pyrite oxidation and its control. CRC Press. Boca Raton. 293 pp.

Evangelou, V.P. 1999. Environmental Soil and Water Chemistry. J. Wiley and Sons. New York. 567 pp.

Grand, L.F., and A.E. Harvey. 1982. Quantitative measurement of ectomycorrhizae on plant roots. 157-164. In N.C.Schenck (ed). Methods and Principles of Mycorrhizal Research. The Am. Phytopathol. Soc. St. Paul, MN.

Hargreaves, G.H., and Samani, Z.A. (1982) Reference crop evapotranspiration from temperature. Appl. Engrg. in Agric., 1(2):96-99.

Hillel, D. 1998. Environmental Soil Physics. Academic Press: San Diego. 771pp.

Itenfisu, D., R.L. Elliot, R.G. Allen and I.A. Walter. 2000. Comparison of Reference Evapotranspiration Calculations across a Range of Climates. Proc. of the National Irrigation Symposium, November 2000, Phoenix, AZ, American Society of Civil Engineers, Environmental and Water Resources Institute, New York, NY.

Kleinmann, R.L.P. 1989. Acid mine drainage: US Bureau of Mines researches and develops control methods for both coal and metal mines. Engineering and Mining Journal. July 1989.

Koo, B.J., D.C. Adriano and C.D. Barton. 2003. Effects of organic acids on metal bioavailability in coal combustion wastes. J. Environ. Qual. (In Review).

Lalvani, S.B., B.A. DeNeve, and A. Weston. 1990. Passivation of pyrite due to surface treatment. Fuel. 69: 1567-1569.

Monteith, J.L. 1965. Evaporation and the environment. 205-234. In the movement of water in living organisms, XIXth Symposium. Soc. of Exp. Biol., Swansea, Cambridge University Press.

Nadler, A., A. Gamliel and I. Peretz. 1999. Practical aspects of salinity effect on TDRmeasured water content: A field study. SSSAJ. 63:1070-1076.

Natural Resources Conservation Service. 1996. Soil Survey Laboratory Methods Manual. Soil Survey Investigations. Report No. 42 USDA, Washington, DC.

Nordstrom, D.K., Aqueous pyrite oxidation and the consequent formation of secondary iron minerals. In: J.A. Kittrick et al. (ed.) Acid sulfate weathering. SSSA Spec. Pub. No. 17, SSSA, Madison, WI, 1986, 223.

Penman, H.L. 1956. Evaporation: An Introductory Survey. Neth. J. Agr. Sci. 4: 9-29. 
Pierce, W.G., B. Belzile, M.E. Wiseman and K. Winterhalder. 1994. Proceedings of the International Land Reclamation and Mine Drainage Conference. US Dept. of the Interior. SP06B-94, 1994, Vol. 2. pp148-157.

SAS. 1999. SAS/STAT User's Guide, Version 8. SAS Institute Inc. Cary, NC. 3884 pp.

Sparks, D.L., A.L. Page, P.A. Helmke, R.H. Loeppert, P.N. Soltanpour, M.A. Tabatabai, C.T. Johnson, and M.N. Sumner. 1996. Methods of Soil Analysis: Chemical Methods. SSSA Publications, Milwaukee, WI.

Stroosnijder, L. 1987. Soil evaporation: test of a practical approach under semi-arid conditions. Netherlands Journal of Agricultural Science, 35: 417-426.

USEPA. 1994. Methods for the determination of metals in environmental samples. Method 200.2 EPA/600/R-94/111. Washington, DC.

USEPA. 1994. Inductively coupled plasma-mass spectrometry. Method 6020, Rev 0. In SW-846: Test Methods for Evaluating Solid Waste, Physical/Chemical Methods. Office of Solid Waste, Washington, DC.

USEPA. 1996. Microwave assisted acid digestion of siliceous and organically based matrices. Method 3052, Rev 0. In SW-846: Test Methods for Evaluating Solid Waste, Physical/Chemical Methods. Office of Solid Waste, Washington, DC.

Vogel, W.G. 1980. Revegetating surface mined lands with herbaceous and woody species together. In. Trees for Reclamation. USDA Forest Service and Interstate Mining Compact Commission Technical Report.

Walter, I.A., R.G. Allen, R. Elliott, M.E. Jensen, D. Itenfisu, B. Mecham, T.A. Howell, R. Snyder, P. Brown, S. Echings, T. Spofford, M. Hattendorf, R.H. Cuenca, J.L. Wright, D. Martin. 2000. ASCE's Standardized Reference Evapotranspiration Equation. Proc. of the Watershed Management 2000 Conference, June 2000, Ft. Collins, CO, American Society of Civil Engineers, St. Joseph, MI.

\section{APPENDIX}

The following pages contain photographs taken throughout the course of the study. Though not comprehensive, the pictures capture general themes described in the above text and reflect some of the general obstacles and successes of this project. 

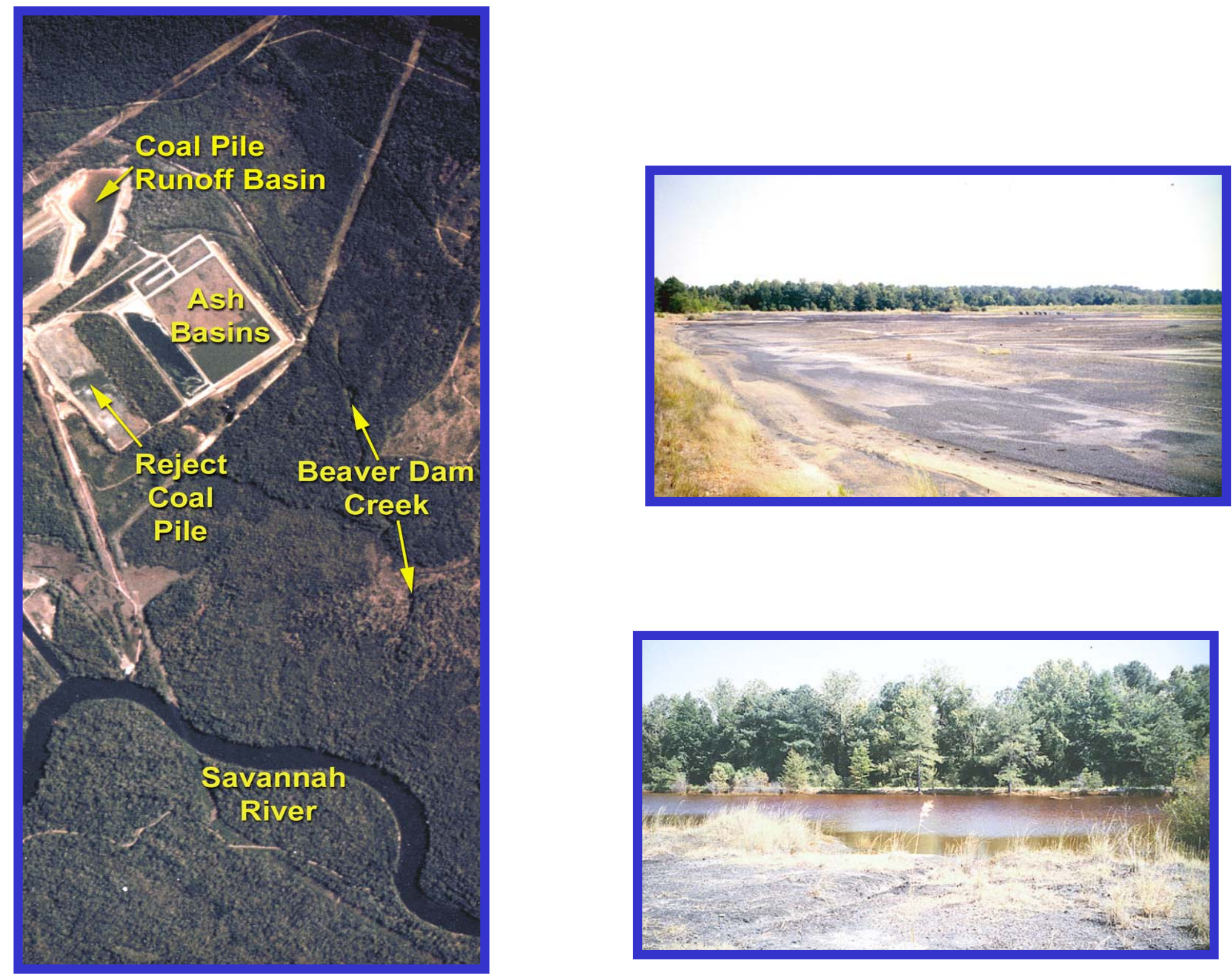

\section{8-D Ash Basin, 1999}

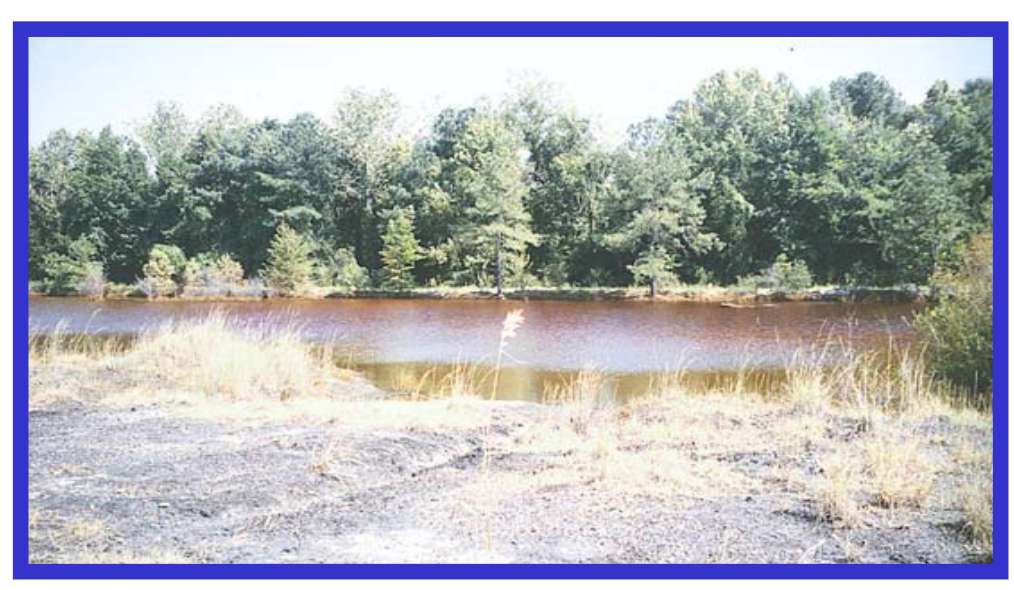




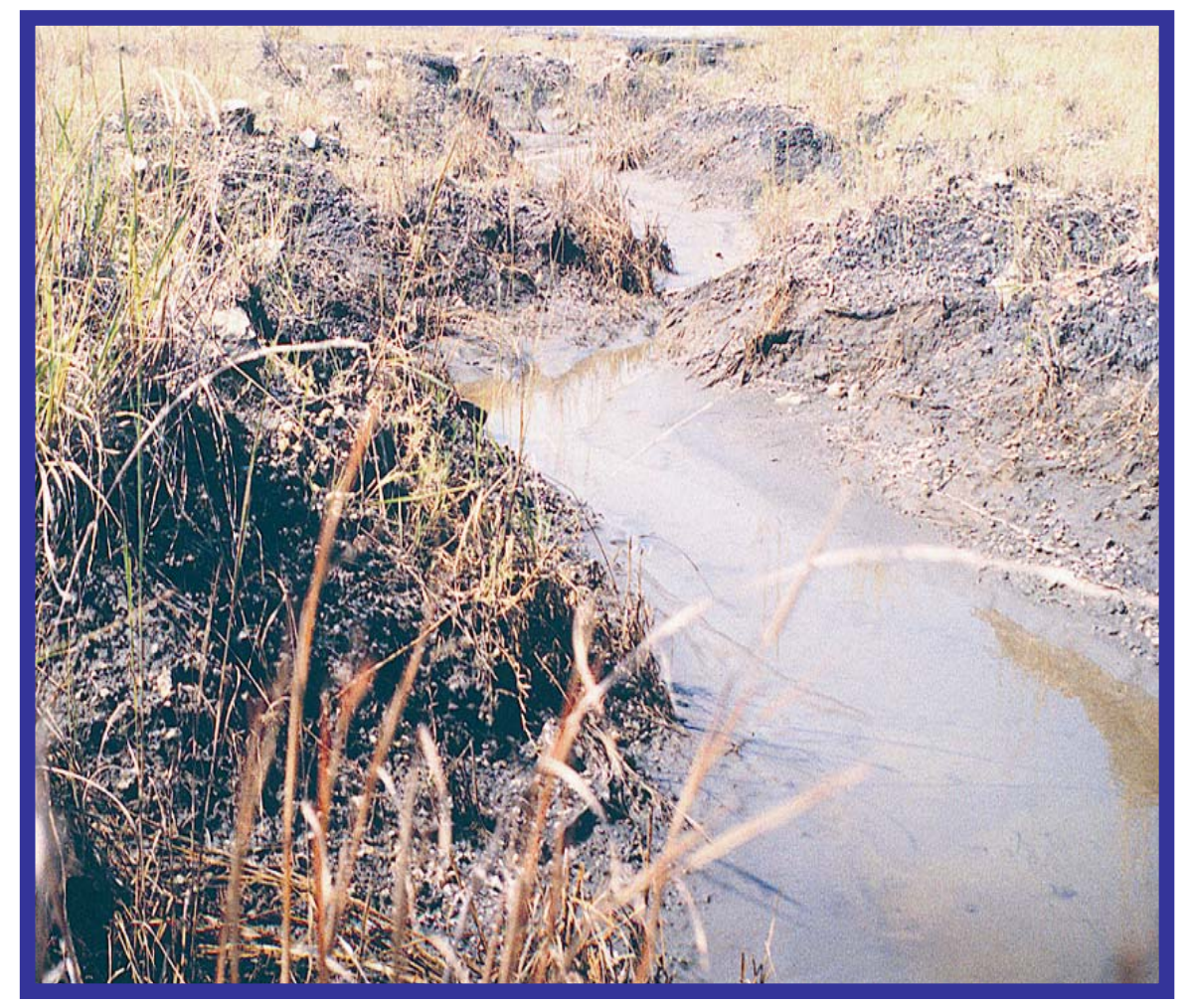

Erosion/Runoff Ditch, 1999 


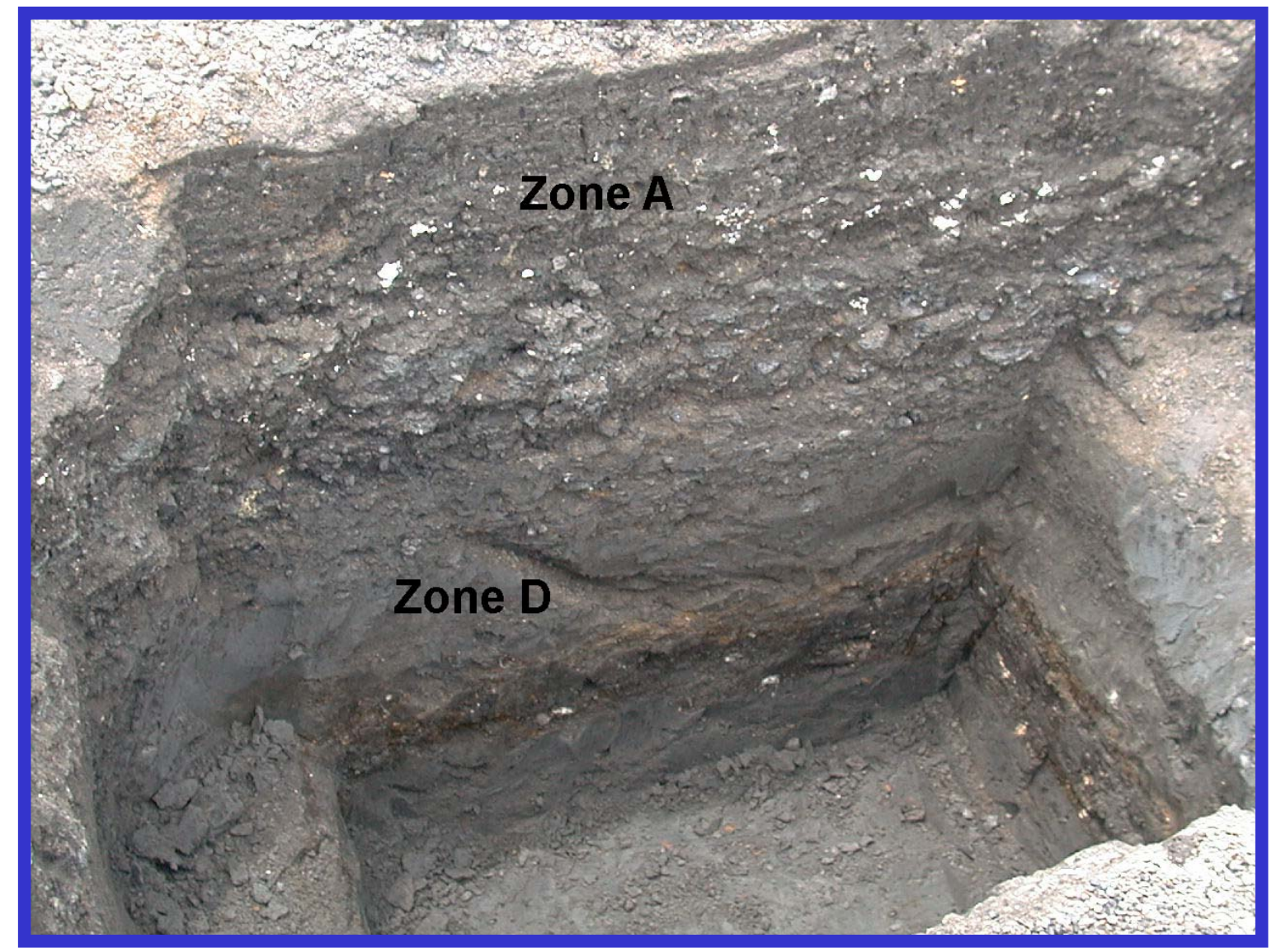

\section{Profile Pit (1.5 meters deep)}




\section{Basin Material Thin Sections}
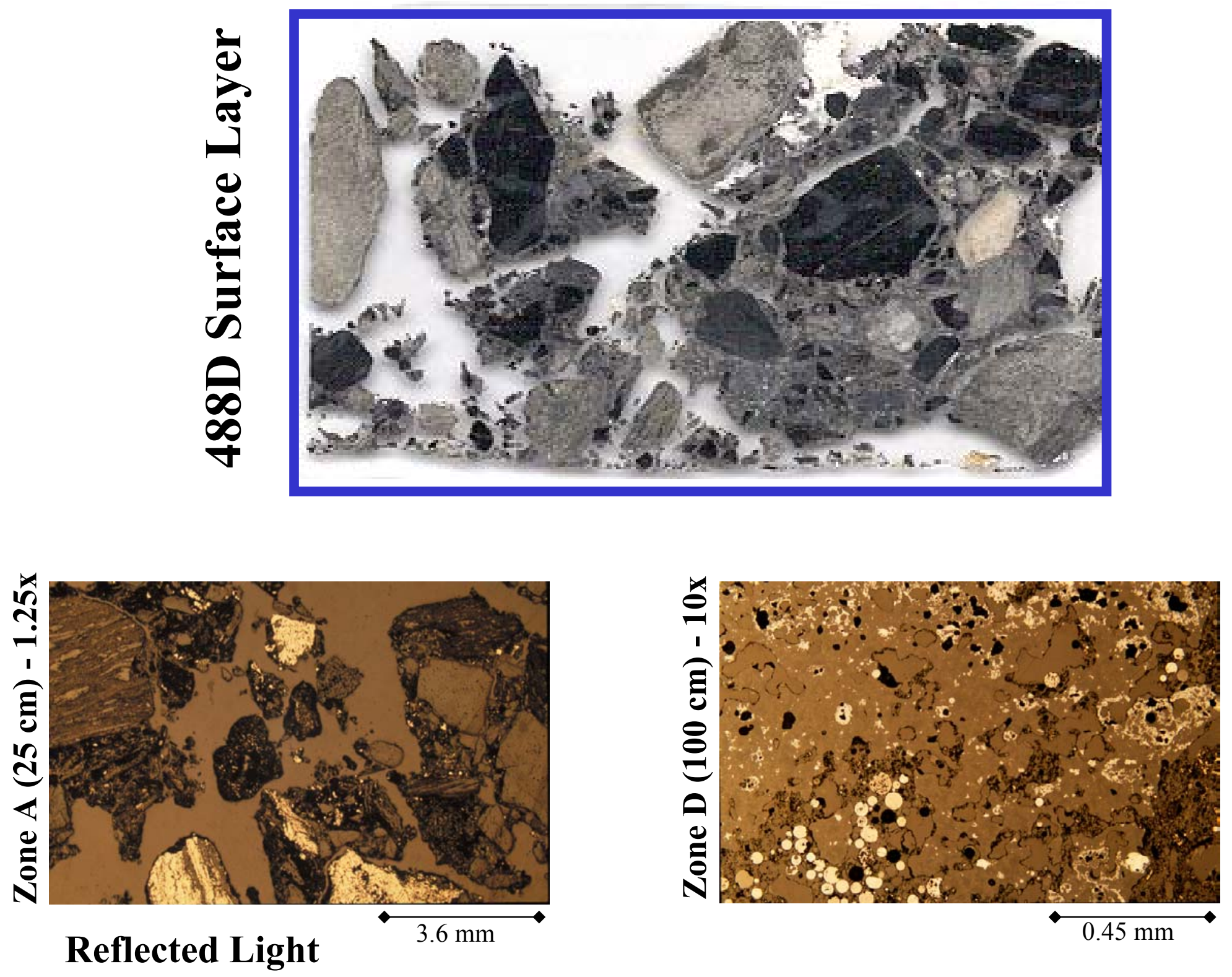


\section{Greenhouse Studies}
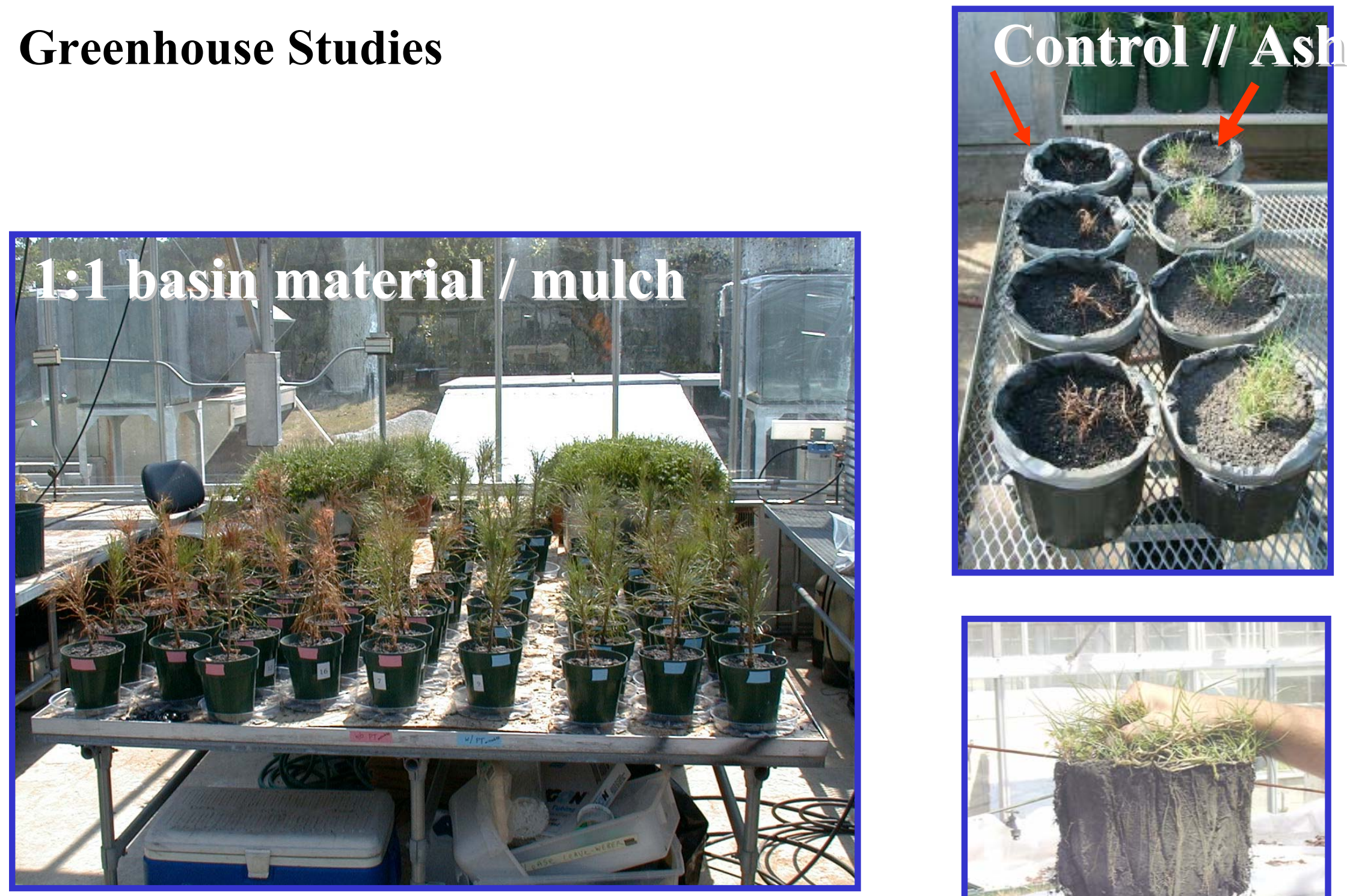

No Pt (red)

With Pt (blue)

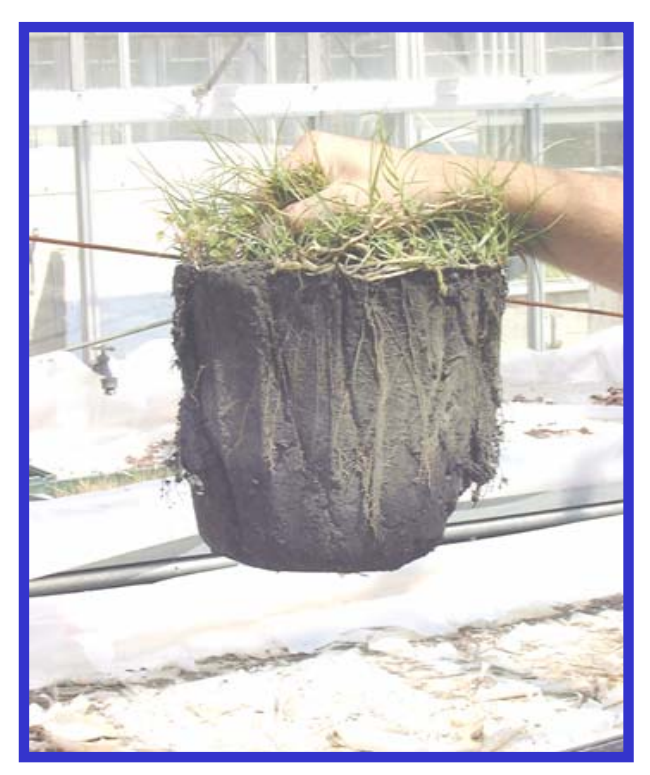



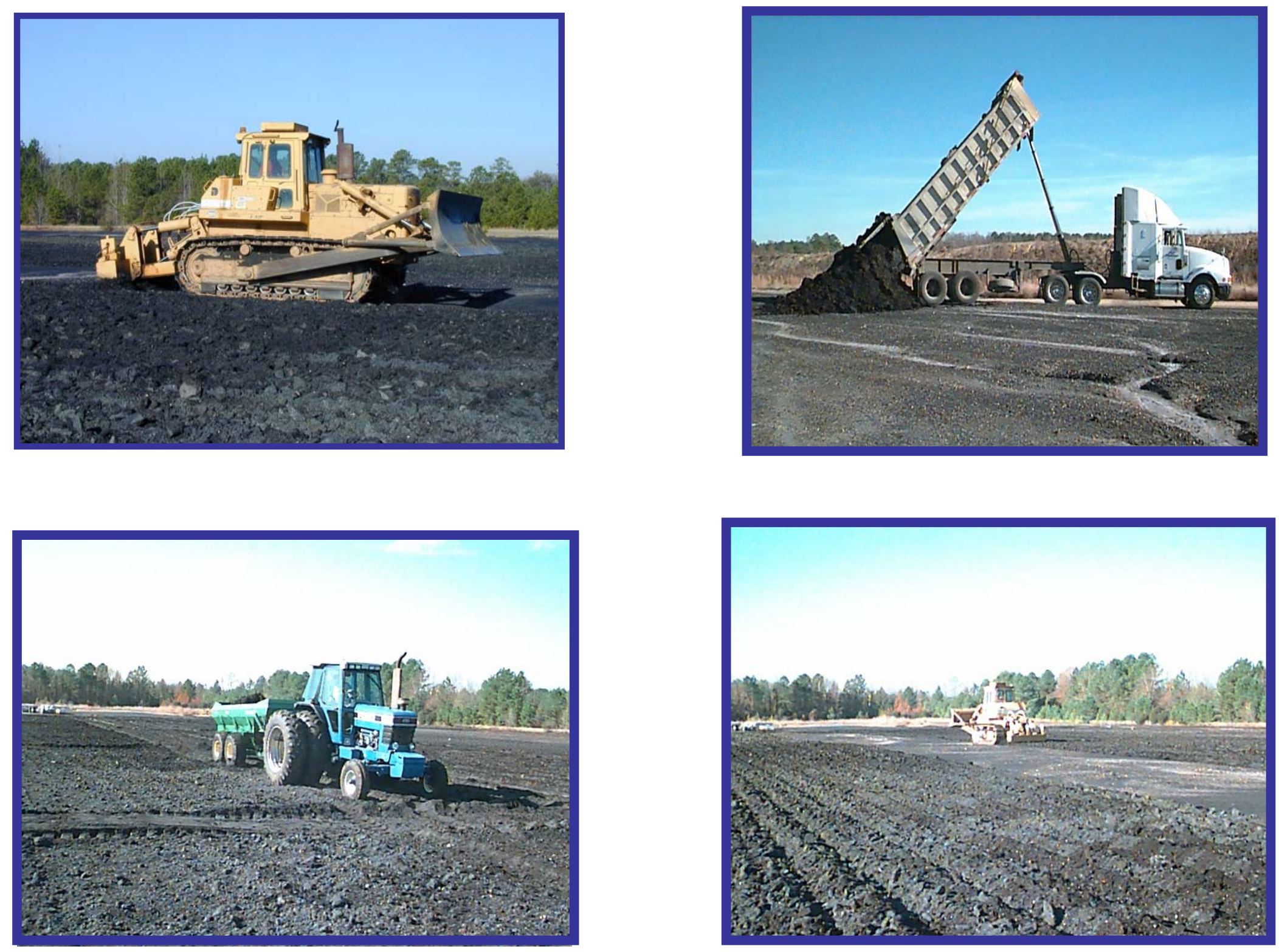

Site Prep, 1999 

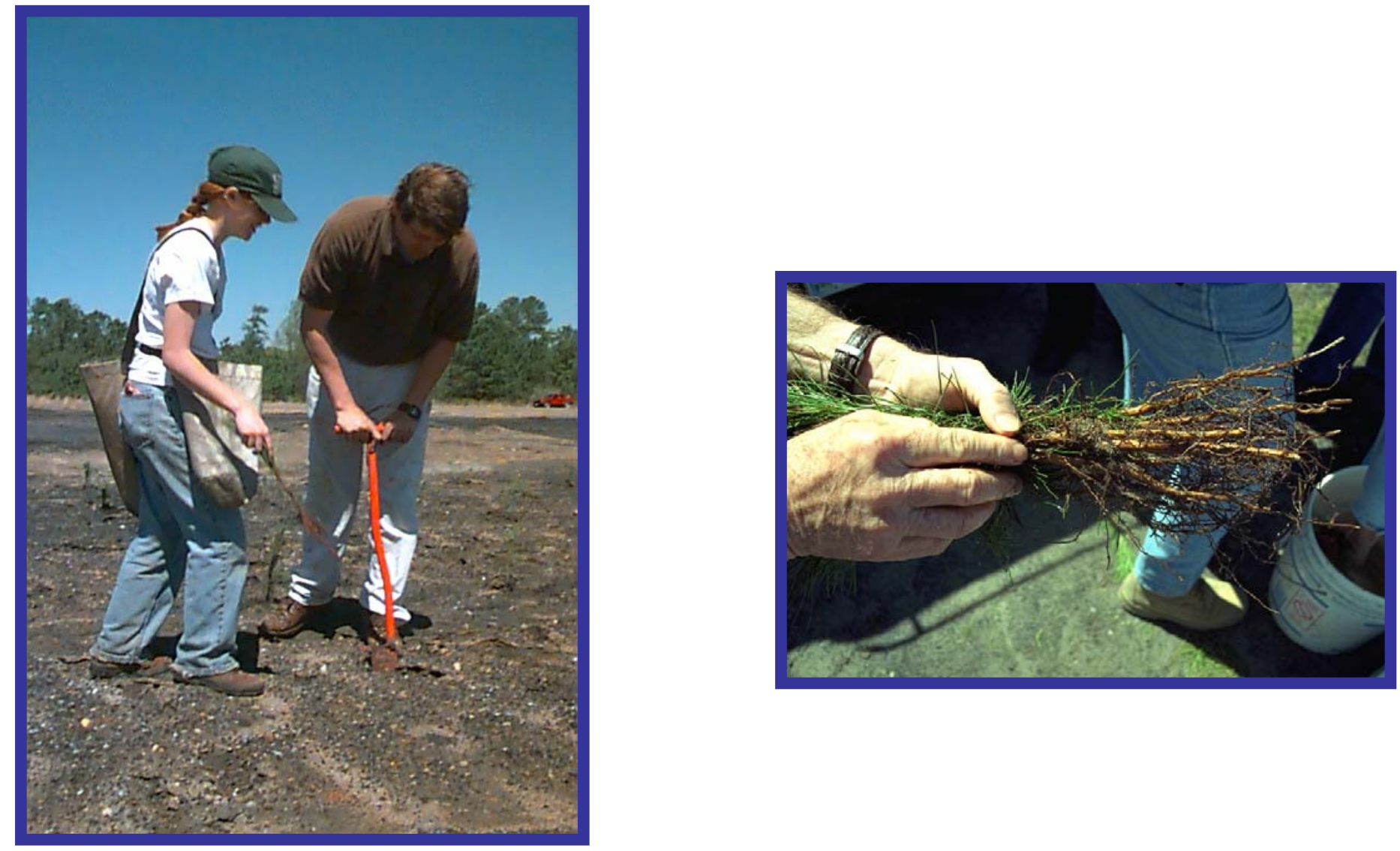

\section{Planting}




\section{8-D Ash Basin (May 2001)}
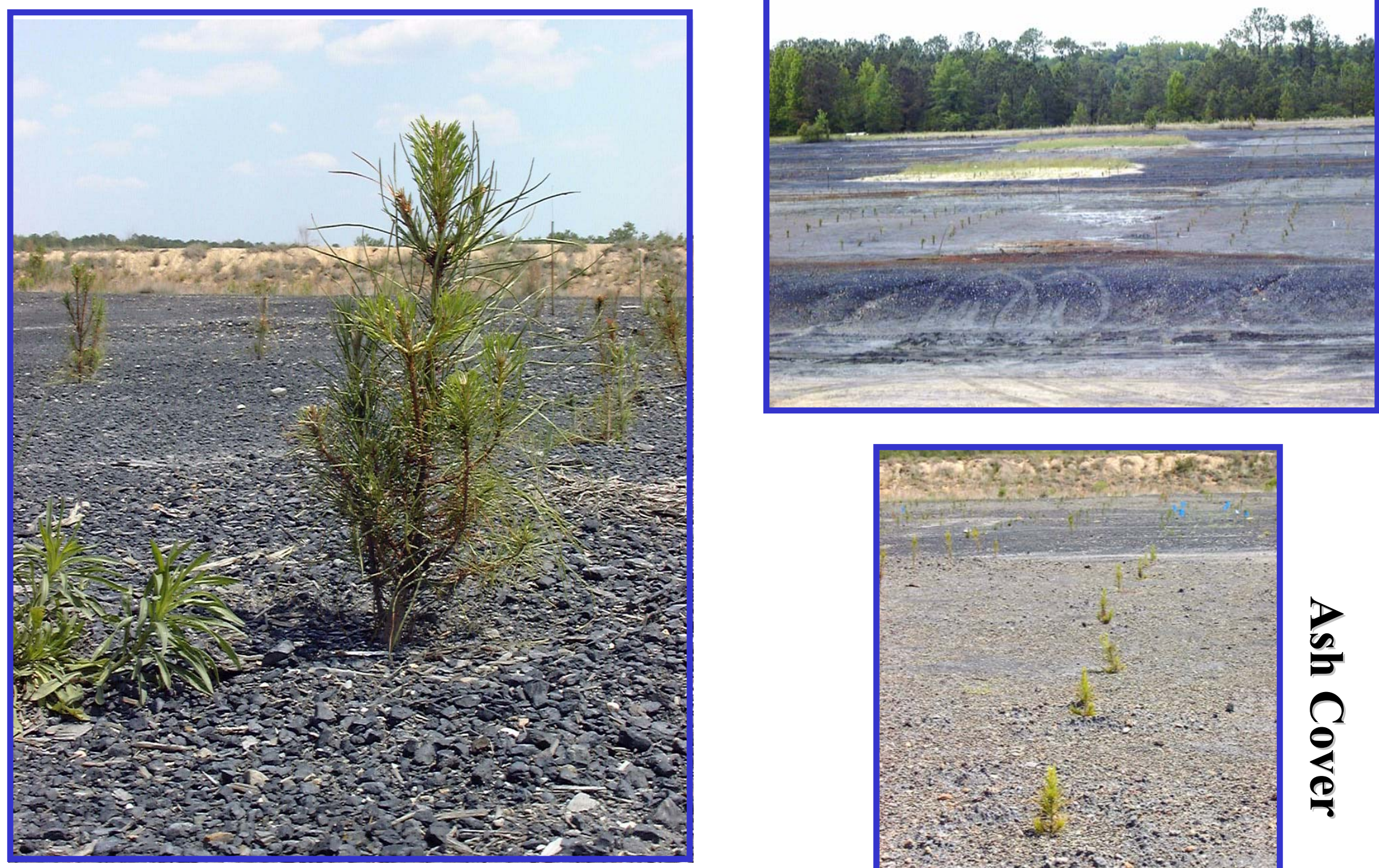

\section{Control (Biosolid Incorporated)}

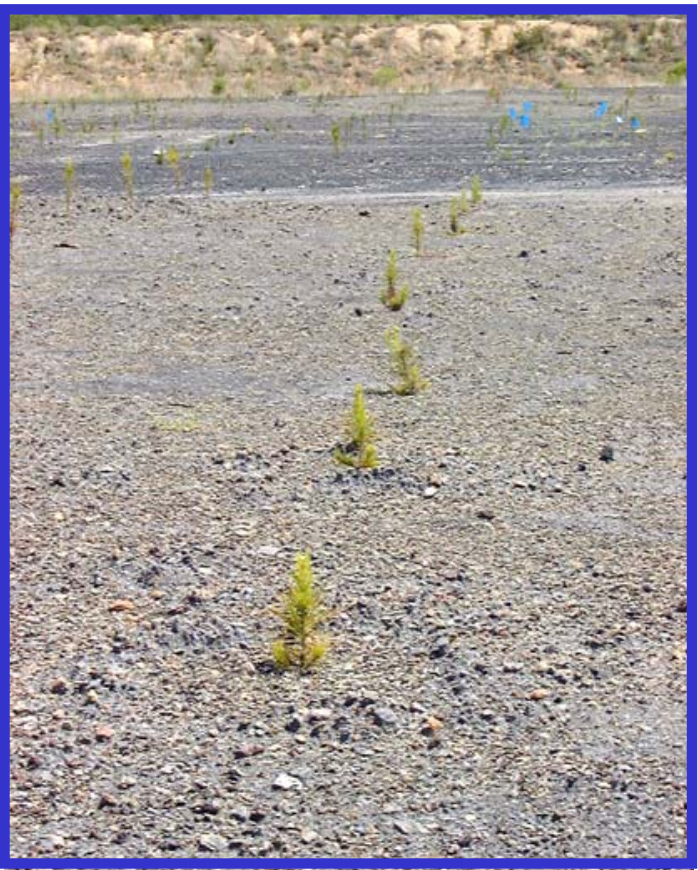

$\frac{8}{2}$ 


\section{September, 2001}
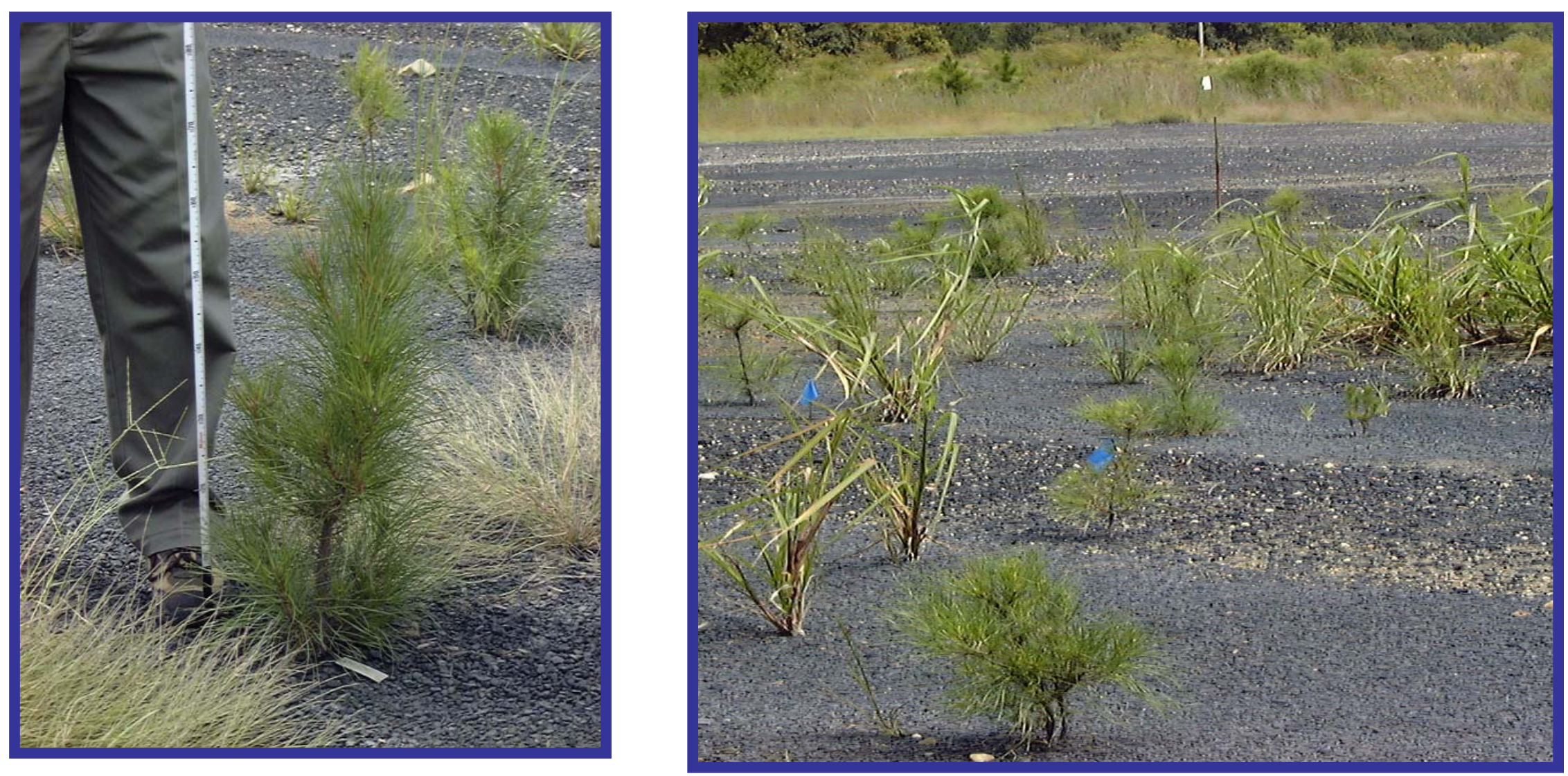


\section{June, 2002}

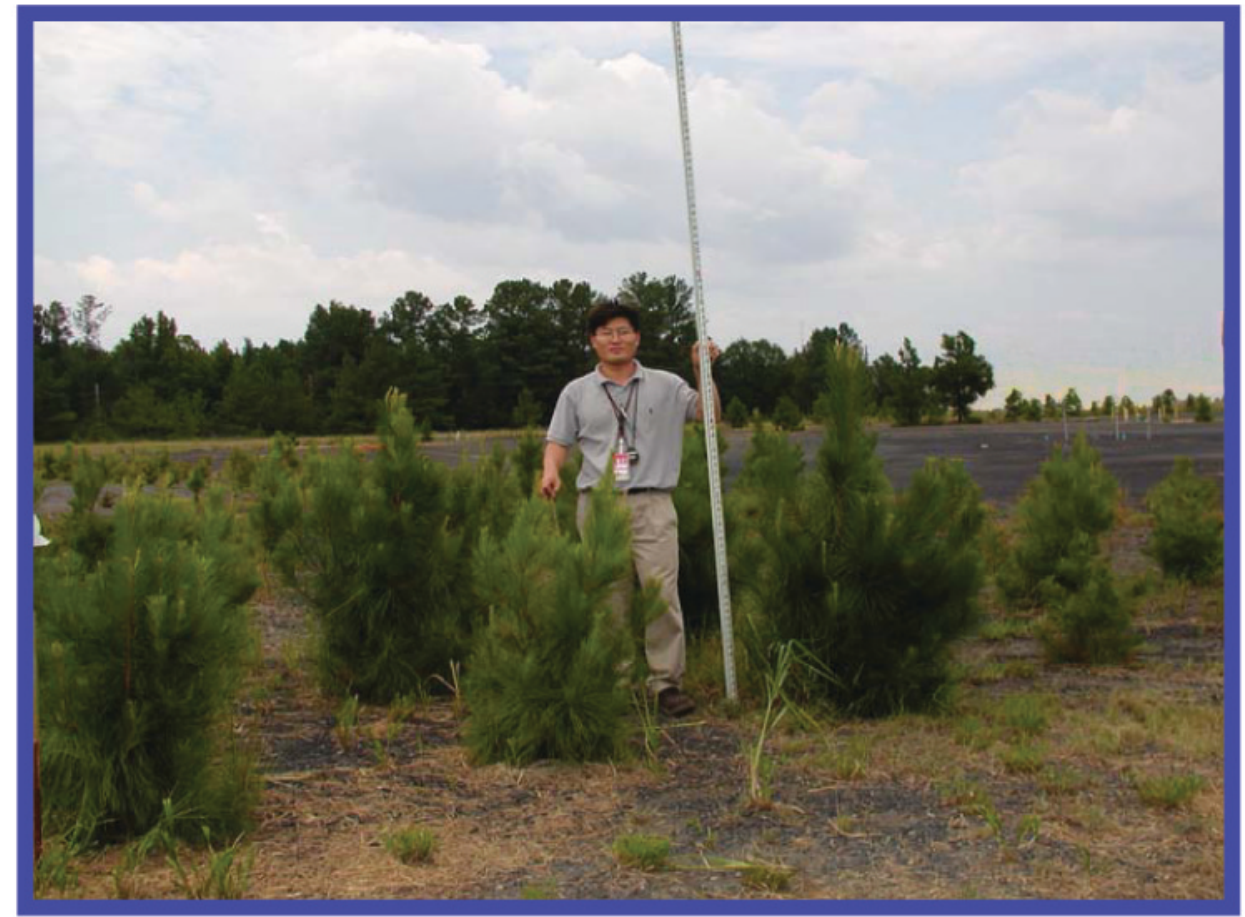

Ripped-compost/Apatite

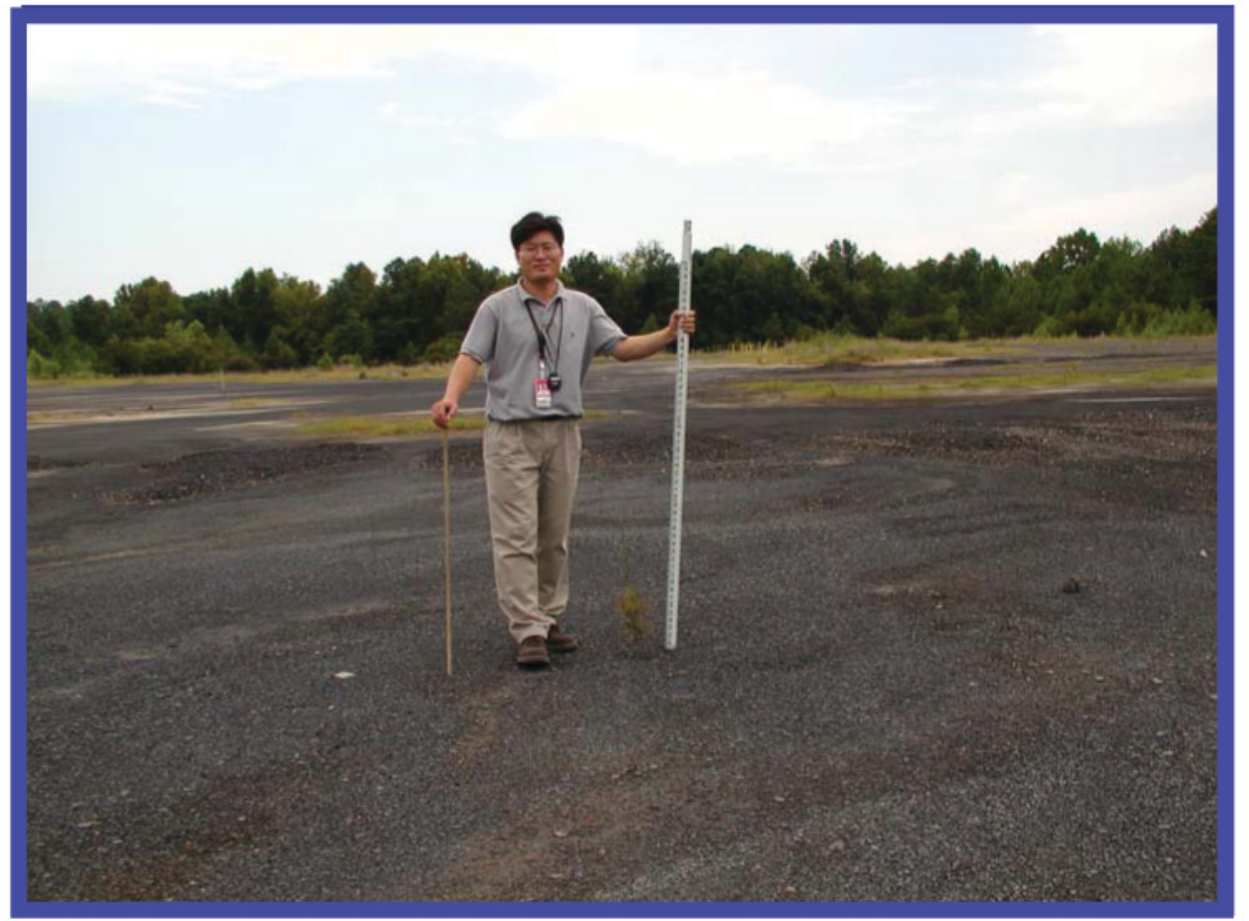

Not Ripped /Control 


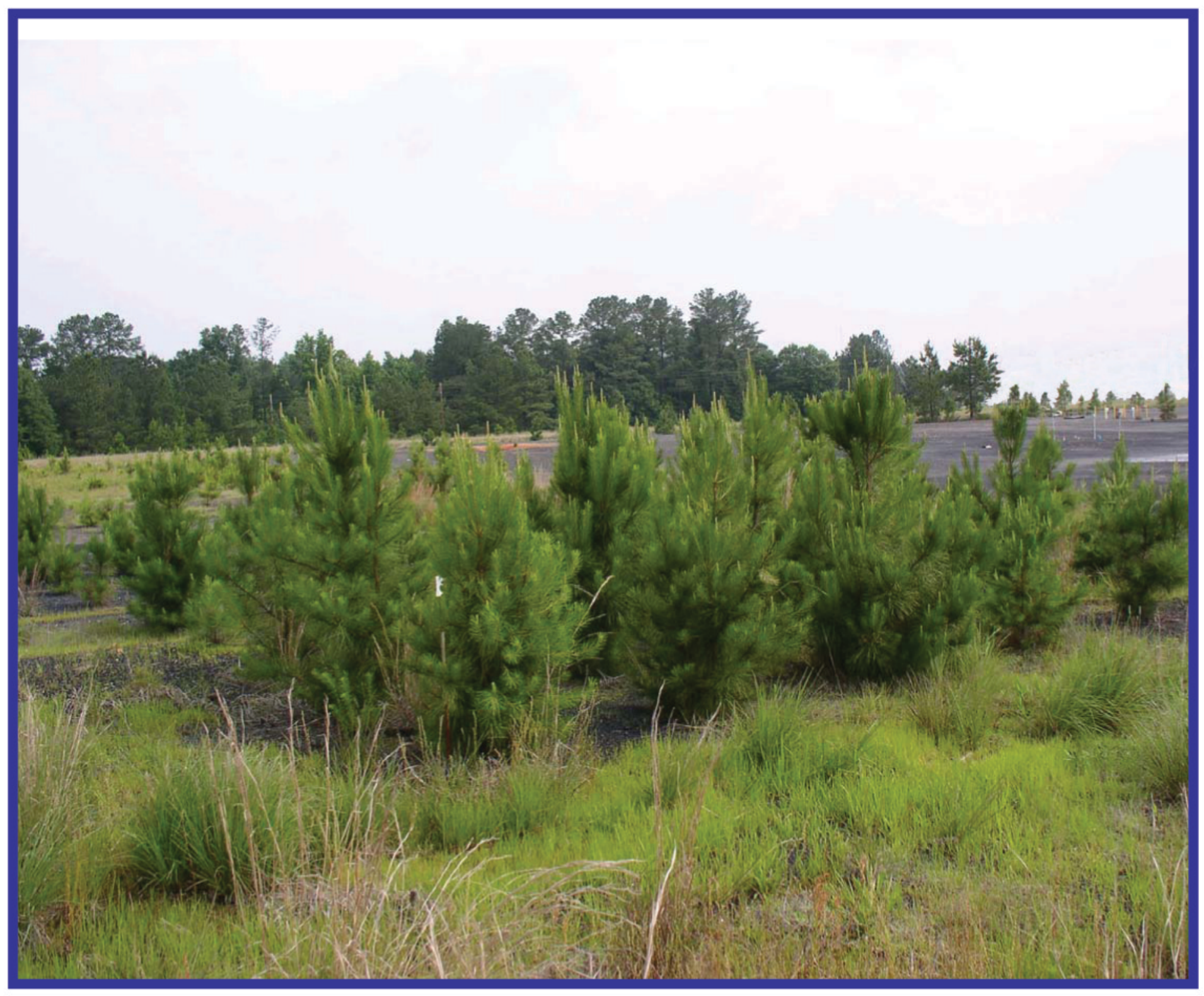

May, 2003: Ripped-compost/Apatite 


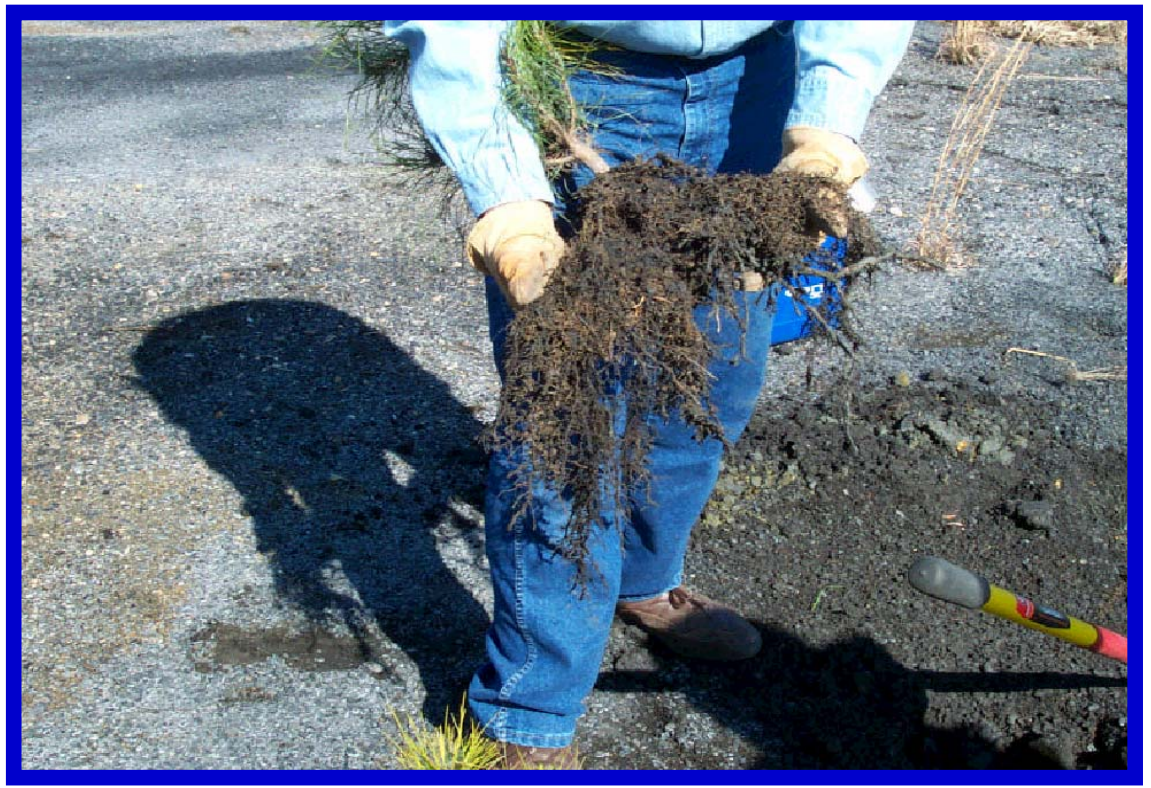

Seedling roots $(t=1$ year $)$

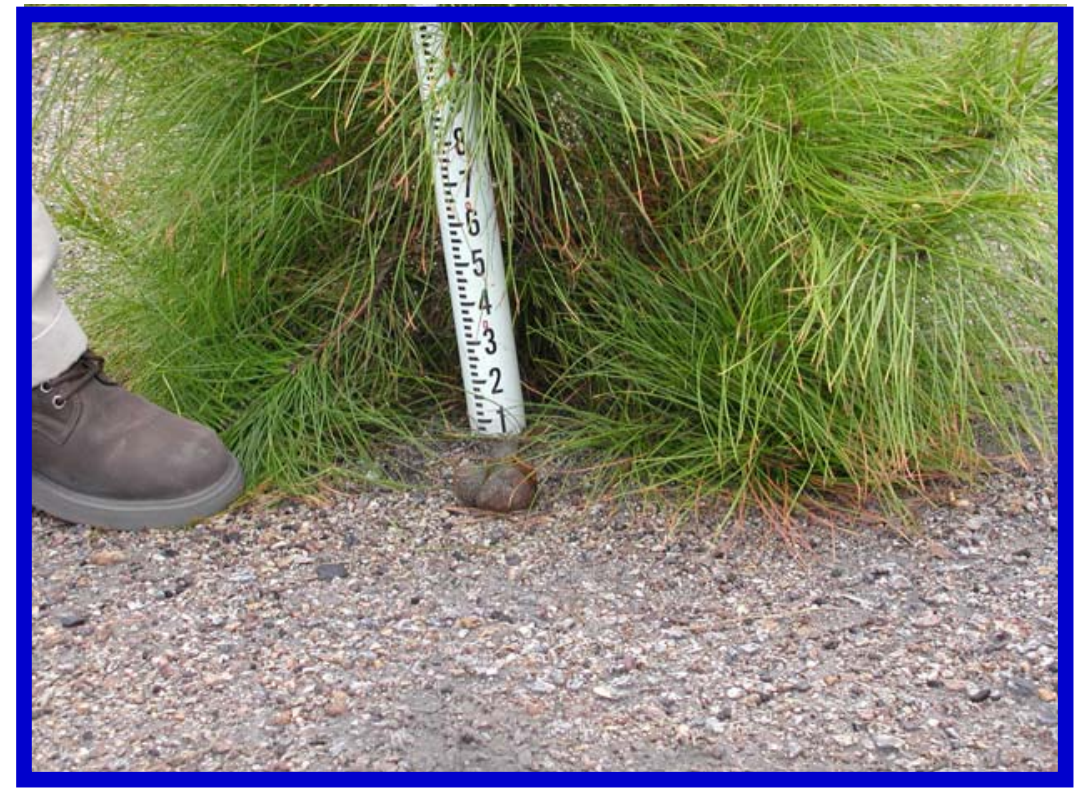

$P t$ fruiting body $(\mathrm{t}=1.5$ year $)$ 


\section{Weather and Soil Moisture Monitoring Equipment Control Plot}

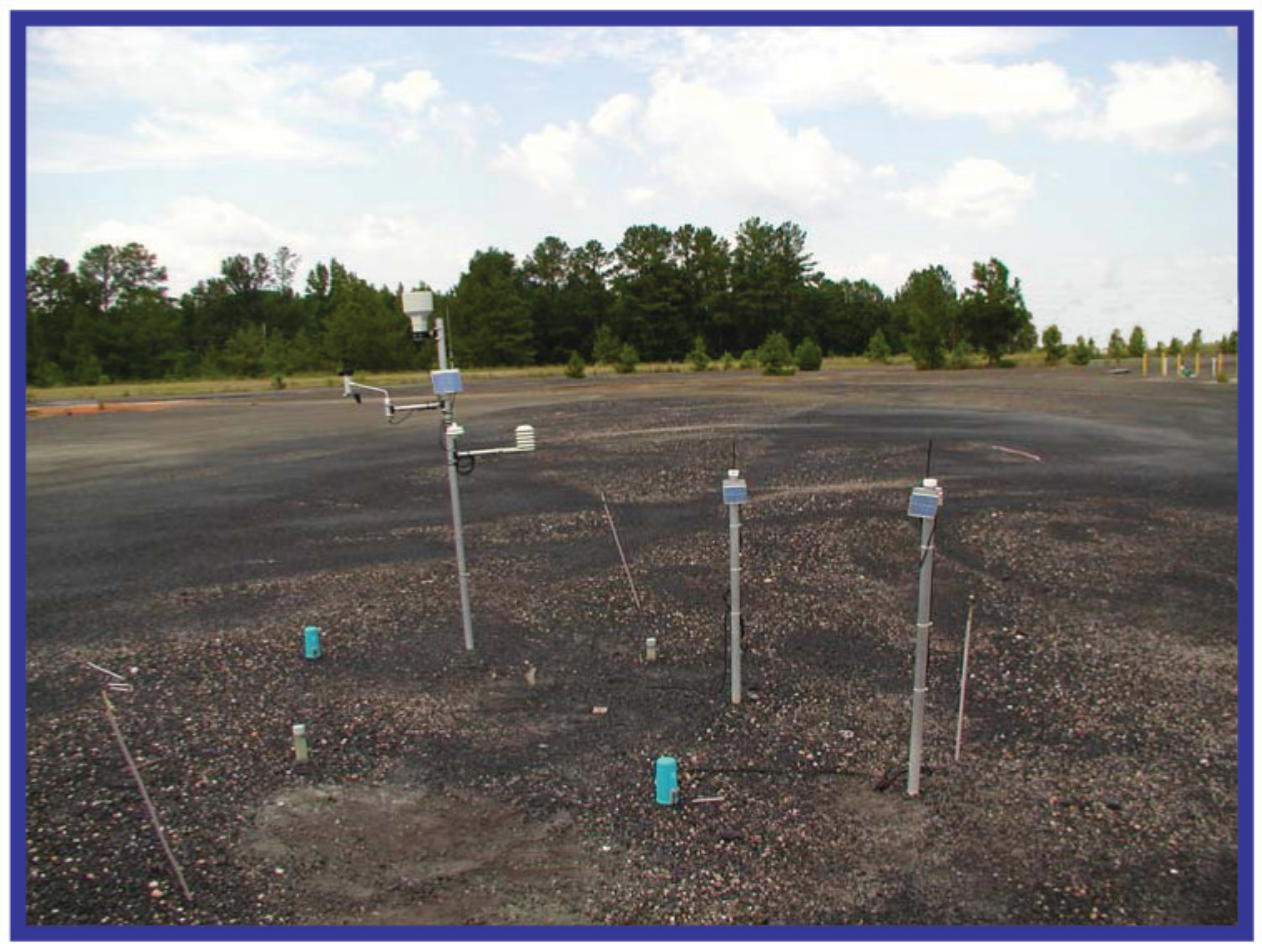




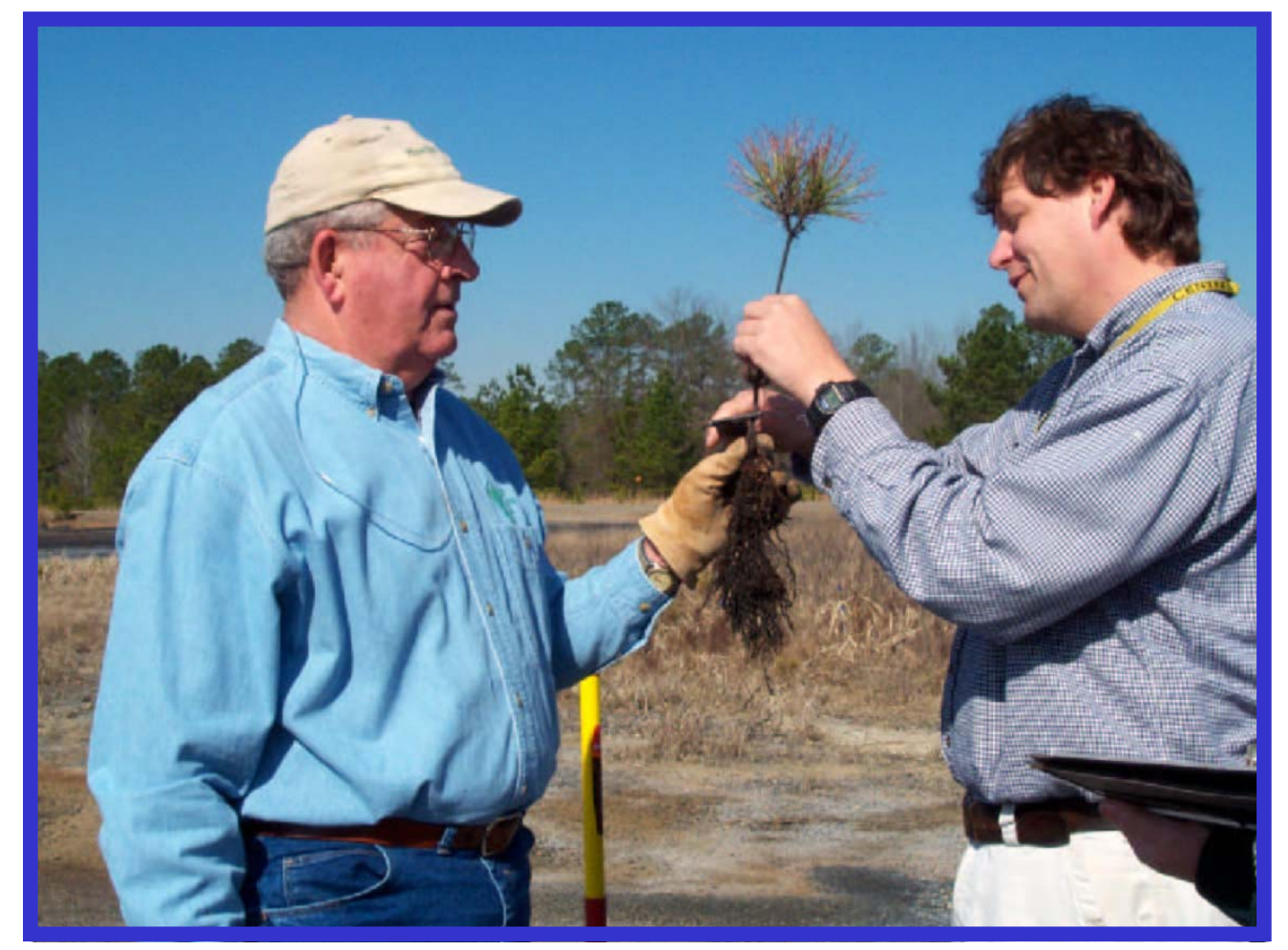

Harvest, 2002 